Florida International University FIU Digital Commons

$11-12-1993$

\title{
Petrology and geochemistry of some high pressure rocks from northern part of Rio San Juan complex, Dominican Republic
}

Khandaker I. Anam

Florida International University

DOI: $10.25148 /$ etd.FI14032311

Follow this and additional works at: https:// digitalcommons.fiu.edu/etd

Part of the Geology Commons

\section{Recommended Citation}

Anam, Khandaker I., "Petrology and geochemistry of some high pressure rocks from northern part of Rio San Juan complex, Dominican Republic" (1993). FIU Electronic Theses and Dissertations. 1284.

https://digitalcommons.fiu.edu/etd/1284 
FLORIDA INTERNATIONAL UNIVERSITY

Miami, Florida

Petrology and geochemistry of some high pressure rocks from northern part of Rio San Juan Complex, Dominican Republic

A thesis submitted in partial satisfaction of the requirements for the degree of Master of Science in Geology

by

Khandaker I. Anam

1994 
To: Dean Arthur w. Herriott

Dean of Arts and Sciences

This thesis, written by Khandaker I. Anam, and entitled Petrology and geochemistry of some high pressure rocks from northern part of Rio San Juan Complex, Dominican Republic, having been approved in respect to style and intellectual content, is referred to you for judgment.

We have read this thesis and recommend that it be approved.

Dr. Claud/a Owdin

$\overline{\mathrm{Dr} \cdot \text { Rosémary Hifjèy } \quad \varnothing}$

Dr. Grenville praper,

Major Professdr

Date of Defense: November 12, 1993

The thesis of Khandaker I. Anam is approved.

Dean Arthur ${ }^{\mathrm{W}}$. Herriott

Dean $\rho^{f}$ Arts and Sciences

Richard L. Campbell

Dean of Graduate Studies

FLORIDA INTERNATIONAL UNIVERSITY, 1994 


\section{ACKNOWLEDGEMENTS}

I would like to thank my advisor Dr. Draper, whose ideas, expertise and encouragement have been invaluable. I would like to thank Dr. Hickey and Dr. Owen for reading the drafts and offering suggestions on ways in which improvements might be made.

I would also thank those who have helped me during the research and preparation of this thesis. Special appreciation is given to my family who cared and gave encouragement to me during this study. 
Petrology and geochemistry of some high pressure rocks from northern part of Rio San Juan Complex, Dominican Republic

Khandaker I. Anam

Florida International University, 1994

Miami, Florida

Professor Grenville Draper, Major Professor

The Rio San Juan Complex is an important occurrence of high pressure/low temperature rocks in the circum-Caribbean region which contains both coherent blueschist units and two varieties of melange in the same area. The melanges contain a diverse assemblage of blocks of various sizes, different degrees of metamorphism, and mineral assemblages. Some high pressure blocks show two stages of metamorphism. The earliest stage is characterized by high pressure-low temperature conditions and the second stage is characterized by high pressure-lower temperature conditions. The geochemistry of thirteen samples from the Rio San Juan Complex has been studied and data have been compared with rocks of adjacent regions. Geochemical evidence indicates that rocks from the Rio San Juan Complex have predominant calc-alkaline affinities with subordinate tholeitic affinities. This suggests that they have a multiple tectonic provenance. 
ABSTRACT

ACKNOWLEDGMENTS . . . . . . . . . . . . . . . iii

TABLE OF CONTENTS . . . . . . . . . . . . . . iv iv

LIST OF FIGURES. . . . . . . . . . . . . . . . . . vi vi

LIST OF TABLES . . . . . . . . . . . . . . . viii

CHAPTER ONE: INTRODUCTION AND GEOLOGIC SETTING. 1 INTRODUCTION . . . . . . . . . . . . 2 GEOLOGIC SETTING . . . . . . . . . . . 5

CHAPTER TWO: PETROGRAPHY AND MINERALOGY . . . . . 11 PETROGRAPHY AND MINERALOGY . . . . . . . . . 12 HICOTEA SCHIST . . . . . . . . . . . 12 PUERCA GORDA SCHIST . . . . . . . . . . 26 JAGUA CLARA MELANGE . . . . . . . . . . . . 32 ARROYO SABANA MELANGE . . . . . . . . . . . 40 SUMMARY OF PETROGRAPHY . . . . . . . . . . . . 42

CHAPTER THREE: CONDITIONS OF METAMORPHISM . . . . 46 CONDITIONS OF METAMORPHISM . . . . . . . . . 47 HICOTEA AND PUERCA GORDA SCHIST . . . . . . . 54 JAGUA CLARA AND ARROYO SABANA MELANGE . . . . . 63 SUMMARY OF CONDITIONS OF METAMORPHISM . . . . . 72 CHAPTER FOUR: GEOCHEMISTRY . . . . . . . . . 75 INTRODUCTION . . . . . . . . . . . . . . . 76 ANALYTICAL METHODS . . . . . . . . . . . 76 
MAJOR AND TRACE ELEMENTS . . • • • . • . . . . . 76

CHAPTER FIVE: DISCUSSION AND CONCLUSIONS . . . . . 95 CONCLUSIONS AND MODEL . . . . . . . . . . . . . 96 SUMMARY OF CHARACTERISTICS OF THE RSJC. • . . . . 96 Field Occurrence. • . . . . . . . . . 96 Protoliths. . . . . . . . . . . . 96 Metamorphism. • • . . . . . . . . . 97 Age Relationship. . . . . . . . . . . 98 TECTONIC MODEL FOR THE DEVELOPMENT OE THE RSJC • • • • • • • • • . . . . . . . 99 FUTURE STUDIES. • • • • . . . . . . . . 102 REFERENCES • . • • . . . . . . . . . . . . . . . 108 APPENDIX I . • • . . . . . . . . . . . . . . . . 120 APPENDIX II . • . • • . . . . • . . . . . • . . . 124 


\section{LIST OF FIGURES}

Page

Figure 1-1. Location Map of northern Hispaniola . . . 4

Figure 1-2. Map of morphotectonic zones of Hispaniola. . 8

Figure 1-3. Geologic Map of the Rio San Juan complex . 10

Figure 2-1. Photomicrograph of the Hicotea Schist . . . 19

Figure 2-2. Photomicrograph of the Hicotea Schist . . 20

Figure 2-3. Photomicrograph of the Hicotea Schist . . . 23

Figure 2-4. Photomicrograph of the Hicotea Schist. . . 24

Figure 2-5. Photomicrograph of the Hicotea Schist . . . 25

Figure 2-6. Photomicrograph of the Puerca Gorda Schist • 30

Figure 2-7. Photomicrograph of the Puerca Gorda Schist . 31

Figure 2-8. Photomicrograph of the Jagua Clara melange . 36

Figure 2-9. Photomicrograph of the Jagua Clara melange . 37

Figure 2-10. Photomicrograph of the Jagua Clara melange . 39

Figure 2-11. Photomicrograph of the Arroyo S. melange . . 44

Figure 2-12. Photomicrograph of the Arroyo S. melange . . 45 
Figure 3-1. P-T conditions for different facies . . . . 48

Figure 3-2. P-T Conditions of the coherent schists . . 62

Figure 3-3. P-T Conditions of the Jagua Clara melange . . 70

Figure 3-4. P-T Conditions of the Arroyo Sabana melange . 71

Figure 3-4. P-T Conditions of the RSJC . . . . . . . 73

Figure 4-1. Miyashiro's diagram.......... . 83

Figure 4-2. AFM diagram.............. . 84

Figure 4-3. $\mathrm{TiO}_{2}, \mathrm{MnO}$ and $\mathrm{P}_{2} \mathrm{O}_{5}$ tectonomagmatic diagram . 85

Figure 4-4. Ti, $\mathrm{Zr}$ and $\mathrm{Y}$ tectonomagmatic diagram . . . 86

Figure 4-5. Ti, $\mathrm{Zr}$ and $\mathrm{Sr}$ tectonomagmatic diagram . . . 87

Figure 4-6. Ti versus $\mathrm{Zr}$ diagram.......... . 88

Figure 4-7. Ti versus $\mathrm{Cr}$ diagram . . . . . . . . . 89

Figure 4-8. Spidergram of trace element . . . . . . 93

Figure 5-1. Tectonic diagram of central Hispaniola . . 104

Figure 5-2. Tectonic evaluation of RSJC . . . . . . 105

Figure 5-3. Tectonic evaluation of RSJC . . . . . . 106

Figure 5-4. Tectonic evaluation of RSJC . . . . . . 107 
Table 2-1. RSJC mineral assemblages . . . . . . . 13

Table 2-2. Melanges and blocks types . . . . . . 15

Table 3-1. Evans facies table... . . . . . . 49

Table 3-2. Different blocks and their P-T conditions 74

Table 4-1. Summary of tectonomagmatic diagrams . . 92

APPENDIX II

Table II-1. Major element data of the RSJC samples . 125

Table II-2. Trace element data of the RSJC samples . 126 


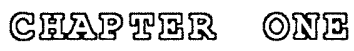

INTRODUCTION AND GEOLOGIC SETTING 


\section{INTRODUCTION}

High pressure rocks are found in various areas of the circum-Caribbean region: mainland Venezuela, Margarita Island, Guatemala, Jamaica, Cuba and northern part of Hispaniola (Figure 1-1). In Hispaniola, these high pressure rocks are found in three different areas: Puerto Plata, Samana and the Rio San Juan Complex (RSJC) all of which are in the Dominican Republic, which occupies the eastern part of the island.

The Rio San Juan Complex is a region of igneous and metamorphic rocks located between Puerto Plata and Samana peninsula. The area covers about $550 \mathrm{~km}^{2}$. The Rio San Juan Complex is almost unexplored geologically. The first account of the geology of the area was in a seaboard oil company report by Beall (1944) which outlined an area of undifferentiated basalt, diorite and schist extending from Gasper Hernandez southward to the Septentrional Fault trace, northeast of San Franscisco de Macoris. More information was given later by Nagle (1974) who first indicated the presence of high pressure rocks in the region. The first systematic study of the area was done by Eberle and others (1982) who named the complex and also described its major rock units. Draper \& Nagle $(1986,1991)$ conducted the first systematic study of the complex and outlined the major petrological and 
structural characteristics. They also named the major units of the complex.

The Rio San Juan Complex contains both coherent blueschist terranes and two types of melange containing blueschist and eclogite blocks in close proximity. The blueschists in these three different settings have different metamorphic histories and probably different provenances. The purpose of this study is to describe in some detail the petrologic, metamorphic and geochemical characteristics of the northern part of the Rio San Juan Complex. The goals of the present study, therefore, are 1) to determine the nature of protolith of the high pressure rocks, especially their geochemical characteristics, and to compare them with rocks of adjacent regions; 2) to determine the metamorphic mineral paragenesis of individual units of the high pressure rocks and so ascertain the conditions of metamorphism; 3) to construct a preliminary tectonic explanation of the petrologic and geochemical characteristics of the rocks of the Rio San Juan complex. 


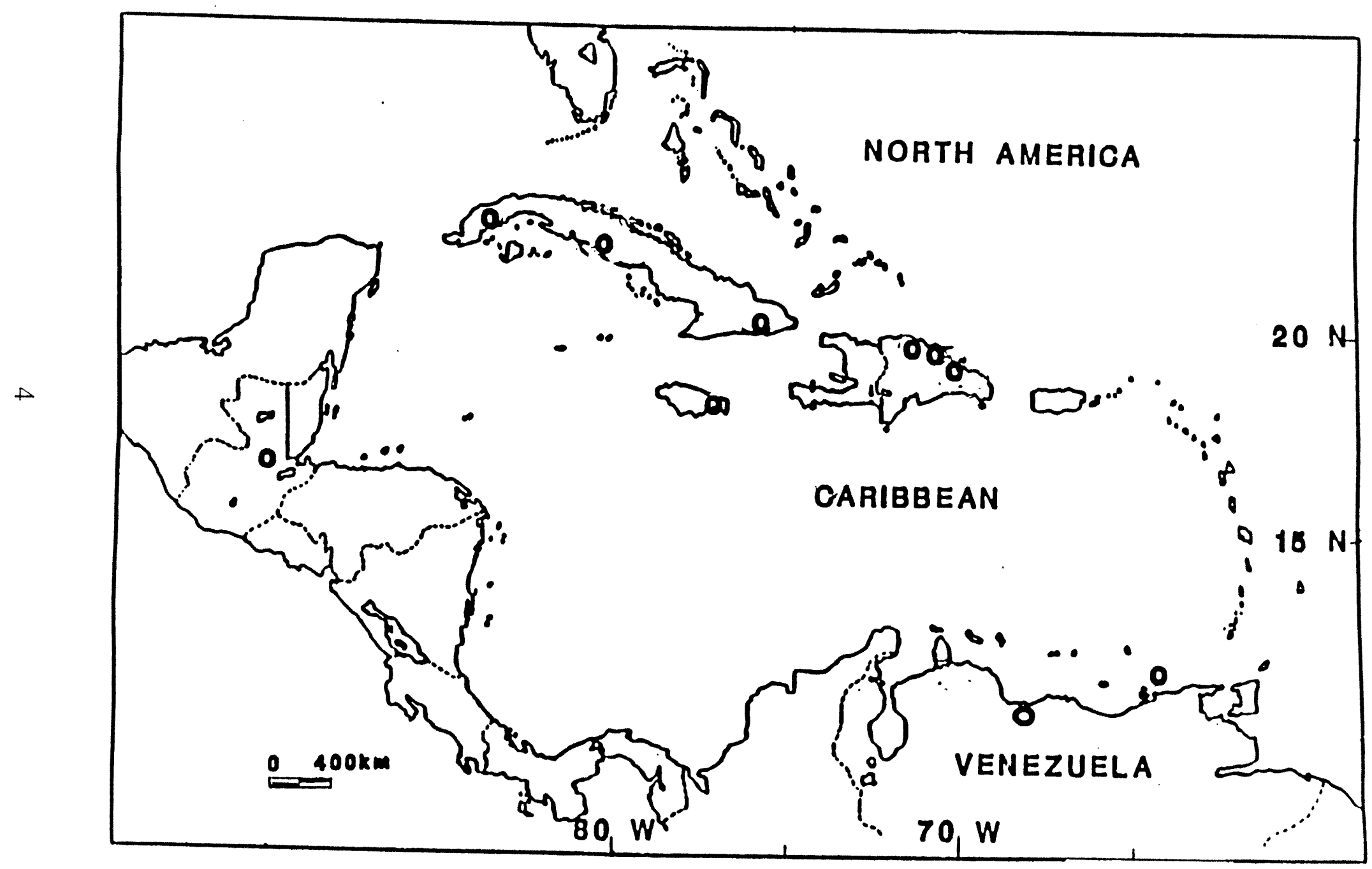

Figure 1-1. Circles are showing location of areas of high-pressure/low-temperature rocks in the circum-Caribbean region. 


\section{GEOLOGIC SETTING}

Hispaniola is the second largest island in the Greater Antilles and is geographically divided into two countries. The Dominican Republic occupies the eastern part of the island and Haiti the western part. Hispaniola forms the north-central segment of the Greater Antilles island-arc chain that extends from Cuba to the Virgin Islands. The island arc activity ceased when the Greater Antilles arc collided with the southern central margin of North America. The timing of the collision was diachronous and occurred in Late Cretaceous to Early-Middle Eocene time in Cuba (Pardo, 1975) Middle to Late Eocene in Hispaniola (Vila and others, 1987) and Late Eocene in the Virgin Islands (Lewis and Draper, 1991).

Hispaniola is a complicated island-arc structure that began to form in Early Cretaceous time (Draper and Nagle, 1986). The interpretation of the early tectonic evolution of Hispaniola is controversial, but it is generally accepted that by Late Cretaceous time the island was part of an arc system that was developing over a probable north-verging subduction system (Nagle, 1974). Nagle's suggestion is supported by presence of blueschists, eclogites, melanges and serpentinite in the northern part of the island and contemporaneous magmatic arc rocks that presently crop out in the high mountain ranges of the cordillera central. 
The Cordillera Septentrional and the Samana Peninsula form the northernmost belt of mountains in the Dominican Republic (Figure 1-2). The Rio San Juan Complex is a part of the Rio San Juan - Pedro Garcia - Puerto Plata terrane (RSJPG-PP) defined by Mann et al. (1991). This terrane is faulted against the Altamira terrane along the Rio Grande and Baja Bonico fault zones. The basal rocks of the western inlier of the RSJ-PG-PP terrane near Puerto Plata consists of serpentinite, gabbro and volcanic rocks (Nagle, 1979; Pindell and Draper, 1991). The basal rocks of the Pedro Garcia inlier consist of tuff and mafic amygdaloidal lava that are intruded by basaltic dikes and a small tonalite stock (De Zoeten and Mann, 1991).

High-pressure/low-temperature metamorphic rocks also occur in the Samana Peninsula. The Samana terrane consists of two coherent low-grade metamorphic units (Joyce, 1991). The coherent rocks consists of lawsonite-pumpellyite-mica schists with some marble layers (Santa Barbara schists). The second unit (Rincon Marble) consists principally of a marble unit with mica schist layers (Joyce, 1991).

\section{Rio San Juan Complex}

The northern part of the Rio san Juan Complex is characterized by a cretaceous coherent blueschist terrane separated by two blueschist and eclogite-bearing serpentinite matrix melanges. These high-pressure rocks occur in inliers 
(erosional windows) beneath the upper Eocene and younger sedimentary rocks. The Rio Boba Intrusive Suite and Cuaba Amphibolite occur in the southern part of the Rio San Juan complex. Rocks of the Rio Boba Intrusive Suite consist of gabbro of varying composition. The Cuaba Amphibolites are generally coarse-grained gneissic rocks. It has been suggested by Draper et al. (1991) that the southern part of the Rio San Juan Complex was formed either as part of the magmatic arc or by intrusion of fore-arc gabbroic magma into the fore-arc basement.

Eberle et al. (1982) in their paper stated that the igneous and metamorphic rocks in the RSJC represent a dismembered ophiolite. Draper et. al (1991) rejected this model noting that a complete single ophiolite suite in the RSJC was unlikely because the units show differing metamorphic grades.

The northern part of the RSJC, which is the object of this study consists of five units (Figure 1-3) of highpressure/low-temperature rocks (Draper \& Nagle, 1986, Draper and others, 1991). These five units are:

1. Hicotea Schists - The unit consists of fine grained greenschists and blueschists. They are pervasively fractured and have a brecciated appearance. White marble layers are present, but these are not brecciated. 


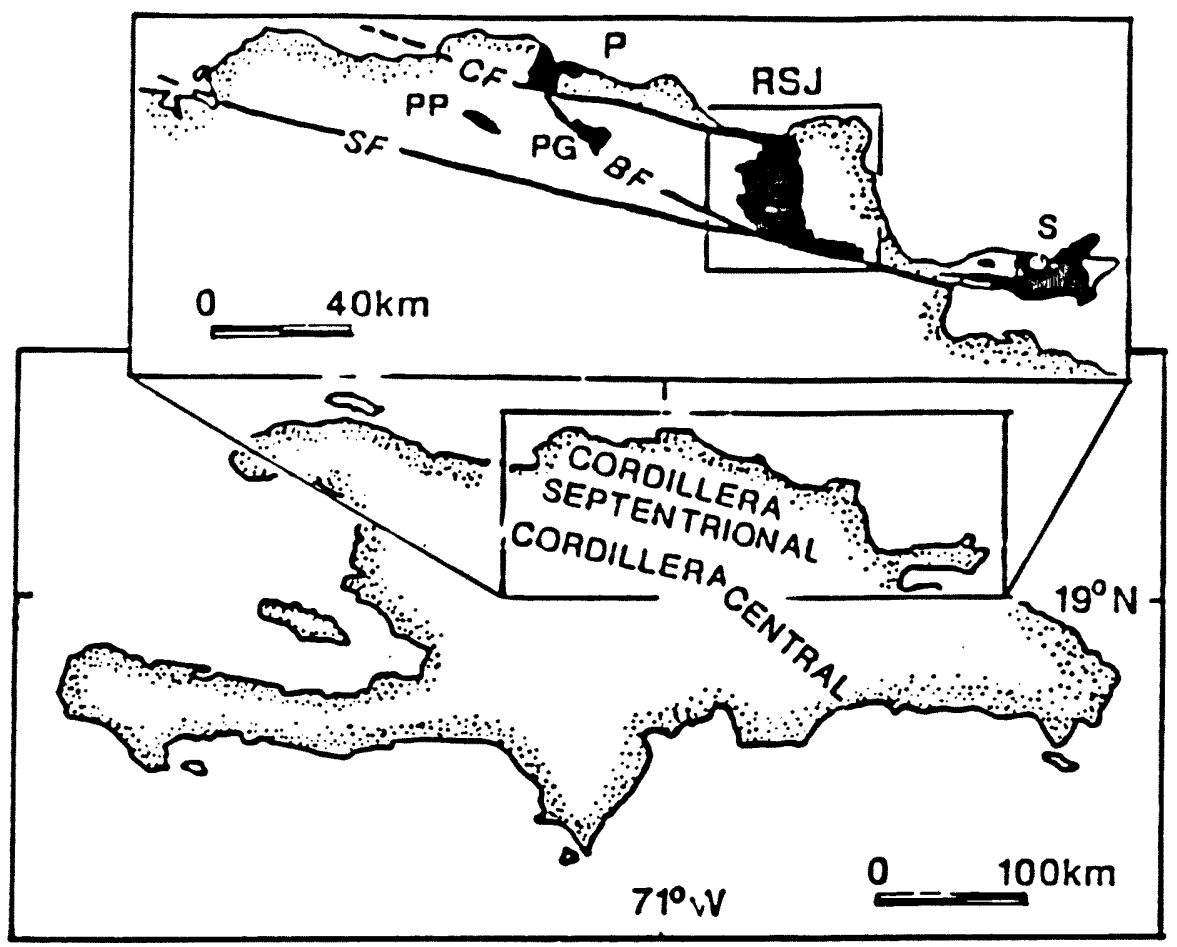

Figure 1-2. Location of areas of pre-Eocene rocks in northern Hispaniola shown in Black. Samana (S), Puerto Plata (P) areas. Cretaceous volcanic rocks are found in the Pedro Garcia (PG) area, and possible Paleocenelower Eocene volcanic rocks are in the Palma Picada

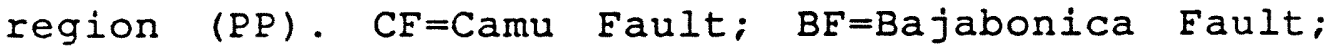
$\mathrm{SF}=$ Septentrional Fault (after Draper and Nagle, 1991). 
2. Puerca Gorda Schists - The texture and composition of these rocks are similar to the Hicotea schists, but the Puerca Gorda Schists lack the marble layers. This unit also contains decimeter to meter scale bands of quartzofeldspathic schists which are intercalated with the more mafic rocks.

3. El Guineal Schist - The El Guineal Schists are located west-central part of the complex. They are fine grained quarzofeldspathic schists. The El Guineal Schists are less mafic in composition than the Puerca Gorda Schist.

4. Jagua Clara Melange - This unit crops out between the Hicotea and Puerca Gorda Schists. The melange consists of blocks of coarse-grained blueschists and eclogites in a serpentinite matrix. Garnetiferous blueschist is common in Jagua Clara melange. The blocks range in diameter from $.5 \mathrm{~m}$ to as much as $5 \mathrm{~m}$.

5. Arroyo Sabana Melange.- This melange contains finegrained blocks of blueschist, greenschist, amphibolite, marble, and diabase blocks. Garnetiferous blueschist is not as common as in the Jagua Clara Melange. The unit is also characterized by felsic blocks of meta-plagiogranite. It is also distinct from the Jagua Clara melange on basis of the mineral original make up of the blocks. The Arroyo Sabana melange also occurs in some places as separate small bodies. 

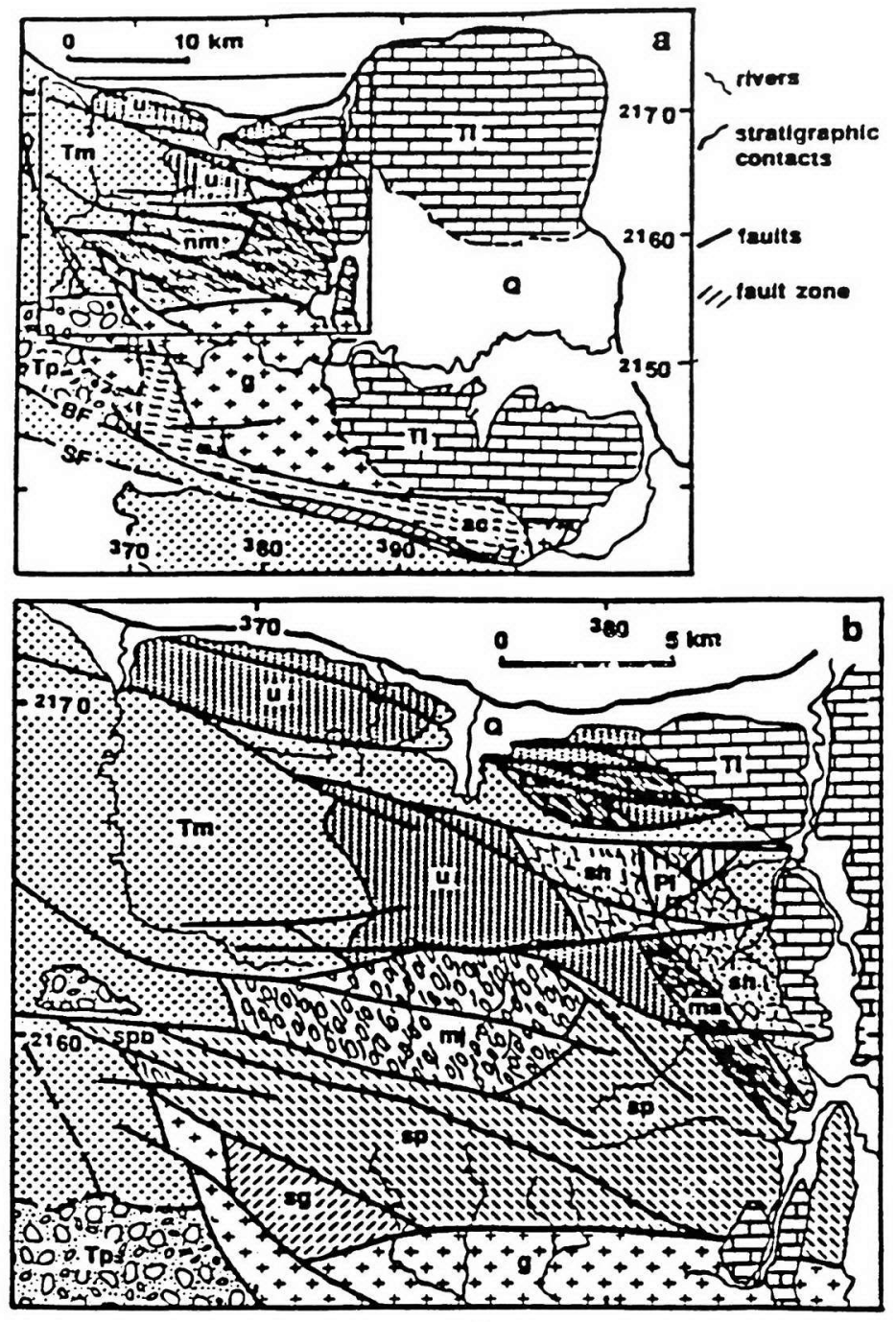

Figure 1-3. Geologic maps of the Rio San Juan complex (based on 1:50,000). a. Whole complex; ac=Cuaba amphibolites: $g=R i o$ Bobo intrusive; $u=G a s p a r$ Hernandez; nm=metamorphic rock units of the northern part of the complex; Tm=Upper Eocene to Oligocene clastic rocks; $\mathrm{T} i=N$ Nogene limestones; $Q=Q u a t e r n a r y$ alluvium and reef deposits; $b=$ Northern part of the Rio San Juan complex; $\mathrm{P} i=$ Imbert Formation; mj=Jagua Clara melange: ma=Arroyo Sabana melange; sh=Hicotea Schists; $\mathrm{sp}=$ Puerca Gorda Schsits; $\mathrm{spb}=$ brecciated Puerca Gorda Schists; $\mathrm{sg}=\mathrm{El}$ Guineal Schists. All other symbol as for a (after Draper and Nagle, 1991). 


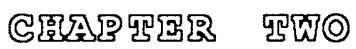

PETROGRAPHY AND MINERALOGY 


\section{PETROGRAPHY AND MINERALOGY}

Rocks collected from the Hicotea schist, Puerca Gorda schist, Jagua Clara melange and Arroyo Sabana melange were examined petrographically. Samples of the El Guineal Schist were not available and therefore are not described here. The petrography of the four different units are summarized below. A total of 26 thin sections were examined by standard petrographic techniques in order to determine the texture, structure and mineral assemblages of the rocks. Mineral assemblages of the twenty six samples are given in table 2-1. Different block types in the melanges are shown in table 2-2.

\section{HICOTEA SCHISTS}

\section{Field Occurrence}

The Hicotea Schists crops out in the northeast corner of the Rio San Juan Complex and consist of fine grained greenschist and blueschist metabasites with associated marble bands. The schists are bluish-gray to greenish-gray in color. A distinctive feature of the Hicotea schist is pervasive fracturing, which gives the outcrop a brecciated appearance. This fracturing does not occur in the white to gray marble layers. 
TABLE: 2-1. RSJC MINERAL ASSEMBLAGES

\begin{tabular}{|c|c|c|c|c|c|c|c|c|c|c|c|c|c|c|}
\hline \multirow[t]{3}{*}{ MINERALS } & \multicolumn{6}{|c|}{$\begin{array}{l}\text { HICOTEA } \\
\text { SCHIST }\end{array}$} & \multicolumn{8}{|c|}{$\begin{array}{c}\text { PUERCA GORDA } \\
\text { SCHIST }\end{array}$} \\
\hline & 83 & 83 & 84 & 84 & 83 & 83 & 83 & 84 & 84 & 83 & 83 & 83 & 83 & 84 \\
\hline & 138 & 139 & 20 & 185 & $191 a$ & 187 & $142 b$ & 13 & 9 & 198 & 77 & 142 & $168 \mathrm{a}$ & $78 a$ \\
\hline Quartz (Qz) & $x$ & $x$ & $x$ & $x$ & $x$ & $x$ & $x$ & $x$ & $x$ & $x$ & $x$ & $x$ & $\bar{x}$ & $x$ \\
\hline albite $(A b)$ & & & $x$ & $x$ & & & $x$ & & $x$ & $x$ & $x$ & $x$ & $x$ & \\
\hline Epidote (Ep) & $\mathrm{x}$ & $x$ & $\mathrm{x}$ & $\mathrm{x}$ & $x$ & $x$ & $x$ & $x$ & & $x$ & & $x$ & $x$ & $x$ \\
\hline \multicolumn{15}{|l|}{ Clinozoisite $(\mathrm{Cz})$} \\
\hline Lawsonite (Lw) & $x$ & $x$ & & & $x$ & $x$ & & & $x$ & & & & $x$ & $x$ \\
\hline Glaucophane (Gl) & & $x$ & & $x$ & $x$ & $x$ & $x$ & & & $x$ & $x$ & $x$ & & $x$ \\
\hline Actinolite (Act) & & $x$ & $x$ & & $x$ & & & & $x$ & $x$ & $x$ & & & \\
\hline Chlorite (Chl) & $x$ & $x$ & & $x$ & $x$ & $x$ & $x$ & $x$ & $x$ & $x$ & $x$ & $\bar{x}$ & $x$ & $x$ \\
\hline Garnet (Gar) & & & $x$ & & & & & & & & & & & \\
\hline White mica (Ph) & & $x$ & $x$ & & & & $\mathrm{X}$ & & $x$ & & & $x$ & $x$ & $x$ \\
\hline Sphene (Sph) & & & $x$ & $x$ & & & & & & $x$ & & & & \\
\hline \multicolumn{15}{|l|}{ Hornblende $(\mathrm{Hb})$} \\
\hline Crossite (Crs) & & & & $\mathrm{x}$ & & & & & & & & $x$ & & \\
\hline \multicolumn{15}{|l|}{ Omphacite (Om) } \\
\hline Calcite (CI) & & & $x$ & & & & $x$ & & $x$ & & & $x$ & & \\
\hline Pumpellyite(Pp) & & & & & $x$ & & & & & & & & & \\
\hline \multicolumn{15}{|l|}{ Apatite (Apa) } \\
\hline \multicolumn{15}{|l|}{ Rutile (Rut) } \\
\hline \multicolumn{15}{|l|}{ Talc (Tc) } \\
\hline Relict Px. & $x$ & & & $x$ & $x$ & $x$ & & & $x$ & & & & & \\
\hline
\end{tabular}

$\mathrm{C}=$ core, $\mathrm{R}=$ rim 
TABLE: 2-1 (CONTINUED). RSJC MINERAL ASSEMBLAGES

\begin{tabular}{|c|c|c|c|c|c|c|c|c|c|c|c|c|}
\hline \multirow[t]{3}{*}{ MINERALS } & \multicolumn{6}{|c|}{$\begin{array}{l}\text { JAGUA CLARA } \\
\text { MELANGE }\end{array}$} & \multicolumn{6}{|c|}{$\begin{array}{l}\text { ARROYO SABANA } \\
\text { MELANGE }\end{array}$} \\
\hline & 84 & 84 & 83 & 84 & 83 & 83 & 84 & 84 & 84 & 83 & 84 & 84 \\
\hline & 16 & 136 & $142 d$ & 100 & $171 \mathrm{~d}$ & $142 \mathrm{C}$ & 12 & 78 & 82 & 144 & 69 & 76 \\
\hline Quartz (Qz) & $\mathrm{x}$ & & $\mathrm{X}$ & $x$ & & & & $\mathrm{X}$ & & & $x$ & \\
\hline albite $(A b)$ & $\mathrm{X}$ & $\mathrm{x}$ & $\mathrm{x}$ & $\mathrm{x}$ & & & & & $x$ & & $x$ & \\
\hline Epidote (Ep) & $x$ & $X C$ & $\mathrm{x}$ & $\mathrm{x}$ & $x$ & $\mathrm{X}$ & $\mathrm{X}$ & $x$ & $x$ & & $x$ & \\
\hline Clinozoisite $(\mathrm{Cz})$ & $x$ & $X R$ & & & & & & & & & & \\
\hline Lawsonite (Lw) & & & & & $\mathrm{x}$ & $\mathrm{x}$ & & & & & & $x$ \\
\hline Glaucophane (Gl) & $X R$ & $x$ & $X R$ & $X R$ & $x$ & $x$ & $x$ & $x$ & $x$ & & $x$ & $x$ \\
\hline Actinolite (Act) & & $x$ & & $x$ & & & & & & $x$ & & \\
\hline Chlorite (Chl) & & $x$ & $x$ & $x$ & $x$ & $x$ & $x$ & $x$ & $x$ & $x$ & $x$ & \\
\hline Garnet (Gar) & $\mathrm{x}$ & $\mathrm{X}$ & $\mathrm{x}$ & $\mathrm{x}$ & & & $\mathrm{X}$ & $\mathrm{x}$ & $x$ & & $x$ & $x$ \\
\hline White mica $(\mathrm{Ph})$ & $x$ & $\mathrm{x}$ & $x$ & $\mathrm{x}$ & $\mathrm{x}$ & $x$ & $\mathrm{x}$ & $x$ & & $x$ & $\mathrm{x}$ & $x$ \\
\hline Sphene (Sph) & $x$ & & & $\mathrm{x}$ & & & $x$ & $x$ & $x$ & & $\mathrm{x}$ & $x$ \\
\hline Hornblende $(\mathrm{Hb})$ & $x c$ & $x$ & $X C$ & & & & & $x$ & $x$ & & $x$ & \\
\hline \multicolumn{13}{|l|}{ Crossite (Crs) } \\
\hline Omphacite $(\mathrm{Om})$ & & $x$ & & $x C$ & $x$ & & & & & & & \\
\hline \multicolumn{13}{|l|}{ Calcite (Cl) } \\
\hline \multicolumn{13}{|l|}{ Pumpellyite(Pp) } \\
\hline Apatite (Apa) & & $x$ & & & & & & & & & & \\
\hline Rutile (Rut) & & $x$ & $x$ & & $x$ & $x$ & & & & & & \\
\hline Talc (Tc) & & & & & & & & & & $x$ & & \\
\hline Relict Px. & & & & & & & & & & & & \\
\hline
\end{tabular}

* $P x=$ pyroxene, $C=$ core, $R=$ rim 
TABLE: 2-2. MELANGES AND DIFFERENT BLOCKS TYPES

\begin{tabular}{|l|l|l|}
\hline \multirow{2}{*}{ BLOCK TYPE } & \multicolumn{2}{c|}{ UNIT } \\
\cline { 2 - 4 } & \multicolumn{1}{c|}{ SAMPLE FROM } & \multicolumn{1}{c|}{ SAMPLE FROM } \\
JAGUA CLARA MELANGE & ARROYA SABANA MELANGE \\
\hline \multirow{2}{*}{ Lawsonite blueschist } & $83-171 \mathrm{~d}, 83-142 \mathrm{c}$ & $84-76$ \\
\hline Epidote blueschist & & $84-12$ \\
\hline Glaucophannic eclogite & $84-136,84-100$ & \\
\hline $\begin{array}{l}\text { Glaucophane-bearing albite- } \\
\text { epidote-amphibolite }\end{array}$ & & $84-82,84-69,84-78 \mathrm{~b}$ \\
\hline Hornblende-garnet blueschist & $84-16,83-142 \mathrm{~d}$ & \\
\hline Metasomatic rind & & $83-144$ \\
\hline
\end{tabular}




\section{Mineralogy}

The schists have compositional alternations of finegrained quartz and albite layers with chlorite, white mica and actinolite layers (Figure 2-4). The most abundant minerals in the Hicotea schists are quartz, chlorite, epidote, albite, white mica (phengite), glaucophane, actinolite and relict pyroxene. Most of these are hydrous minerals. Mineral assemblages are shown in table 2-1. Individual minerals are described below:

Quartz is present as fine grained $(0.05-0.1 \mathrm{~mm})$ xenoblastic crystals which often shows mosaic textures. In some specimens quartz is present as sparodic, podiform aggregates of grains, often elongate parallel to the schistosity. Quartz is the most abundant mineral in the Hicotea schist and some thin sections contain as much as $25 \%$ quartz.

Chlorite: Fine grained chlorite is present in all samples of the Hicotea Schists and displays light green color in plane light, brown interference colors and low birefringence. The chlorite grains are commonly xenoblastic to hypidioblastic and parallel to the foliation.

Epidote has a yellow color in thin section, and is hypidioblastic to idioblastic and inequigranular. It displays characteristic anomalous bright birefringence and high relief. 
White Mica (phengite) in the Hicotea schists is flaky, colorless to pale green in thin section and usually subidioblastic. Phengite is distinguished from paragonite by its green color and smaller $2 \mathrm{~V}\left(0^{\circ}-30^{\circ}\right)$.

Na-amphibole (Glaucophane, crossite) is present in approximately $60 \%$ of the Hicotea Schists samples. Glaucophane is inequigranular, and often prismatic. Where present glaucophane makes up about 6 to $8 \%$ of the rock. This amphibole is identified as glaucophane by its typical paleblue violet color, length slow character, and low intensity pleochroism. It is distinguished from tourmaline by its biaxial negative interference figure, extinction angle and opposite absorption scheme: the stronger absorption by glaucophane is parallel to the length and by tourmaline perpendicular to the length. Crossite is also found in a few samples. Crossite is most easily recognized by its stronger pleochroism. It has a smaller axial angle than glaucophane and its optic axial plane is perpendicular to the length. Zoning in Na-amphibole is not observed in the Hicotea schist.

Lawsonite was identified in a few samples of the Hicotea schist (e.g.83-128, 83-187; table 2-1) and composes about 57\% of each sample. Idioblastic to hypidioblastic lawsonite grains in the Hicotea schists are present as porphyroblasts. Lawsonite shows parallel extinction and moderately to high 
relief (Figure 2-1). Lawsonite is present in thin sections where glaucophane is sparse or absent.

Albite is present in most of the samples of this unit, usually it is associated with quartz, chlorite, epidote, mica and Na-amphibole (glaucophane). Lawsonite is notably absent in albite-bearing rocks. In sample 83-187, albite is present as porphyroblasts. Where present albite makes up 15 to $20 \%$ of the rock. In these rocks, albite often may contain inclusions of epidote and sphene which is one way to distinguish it from quartz. Albite is also distinguished from quartz by biaxial positive figure.

Actinolite is present in several specimen of the Hicotea Schists and occurs as acicular, fine-grained (.05-.08mm) crystals. They exhibit patchy pale-green coloration and birefringence which is probably the result of compositional zonation.

Relict Pyroxene is common in this unit and igneous porphyritic textures are well preserved in some of the rocks. Where present relict pyroxene makes up 8 to $10 \%$ of the rock. The pyroxene is augite (Figure 2-2) and is distinguished from diopside by its pale green color and lower birefringence. In sample 83-187, glaucophane occurs in fractures within relict pyroxene. 


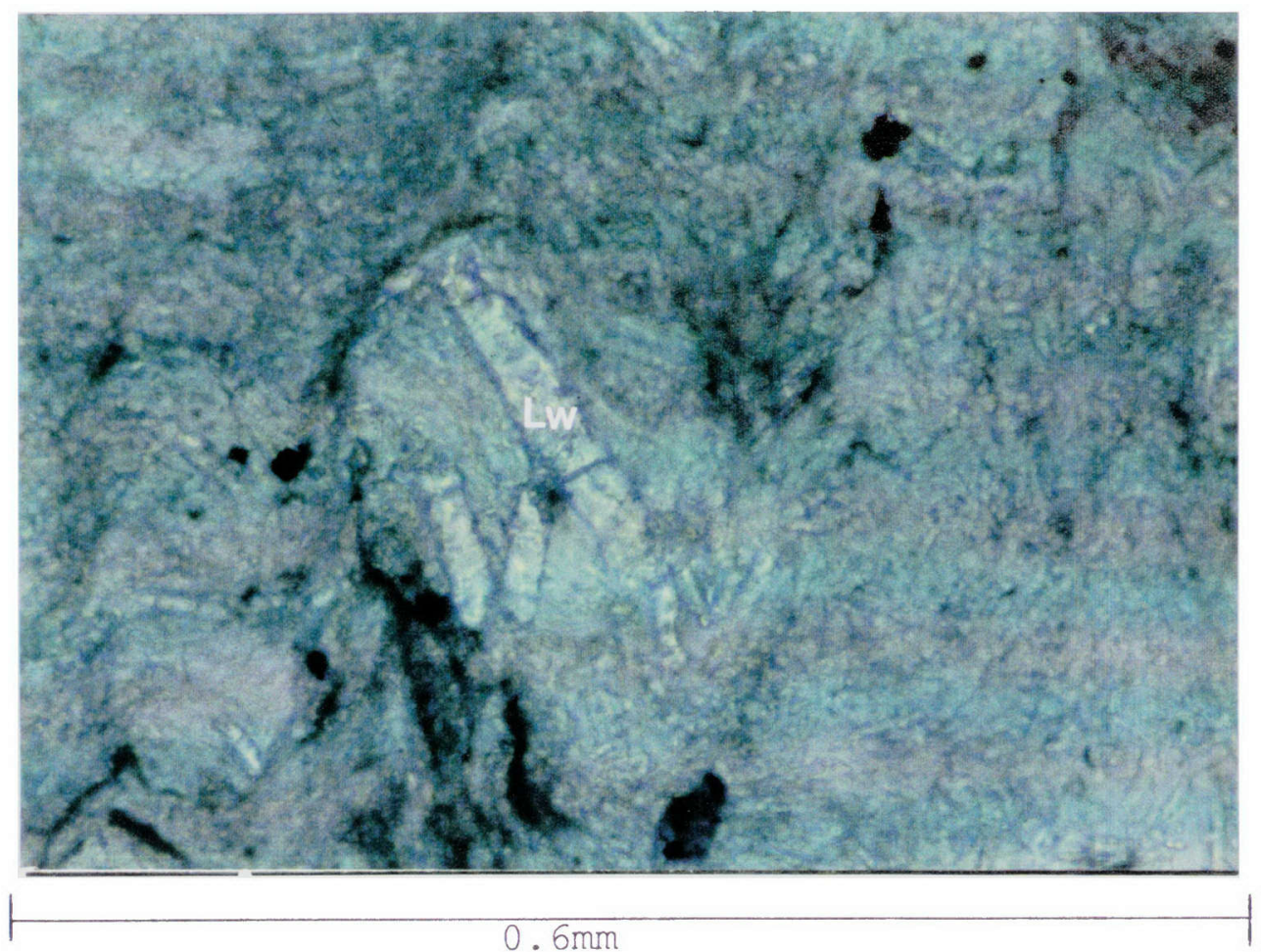

Eigure 2-1. Photomicrograph (plane light) of sample 83-187 (Hicotea Schist). Idioblastic porphyroblast lawsonite (Lw). 


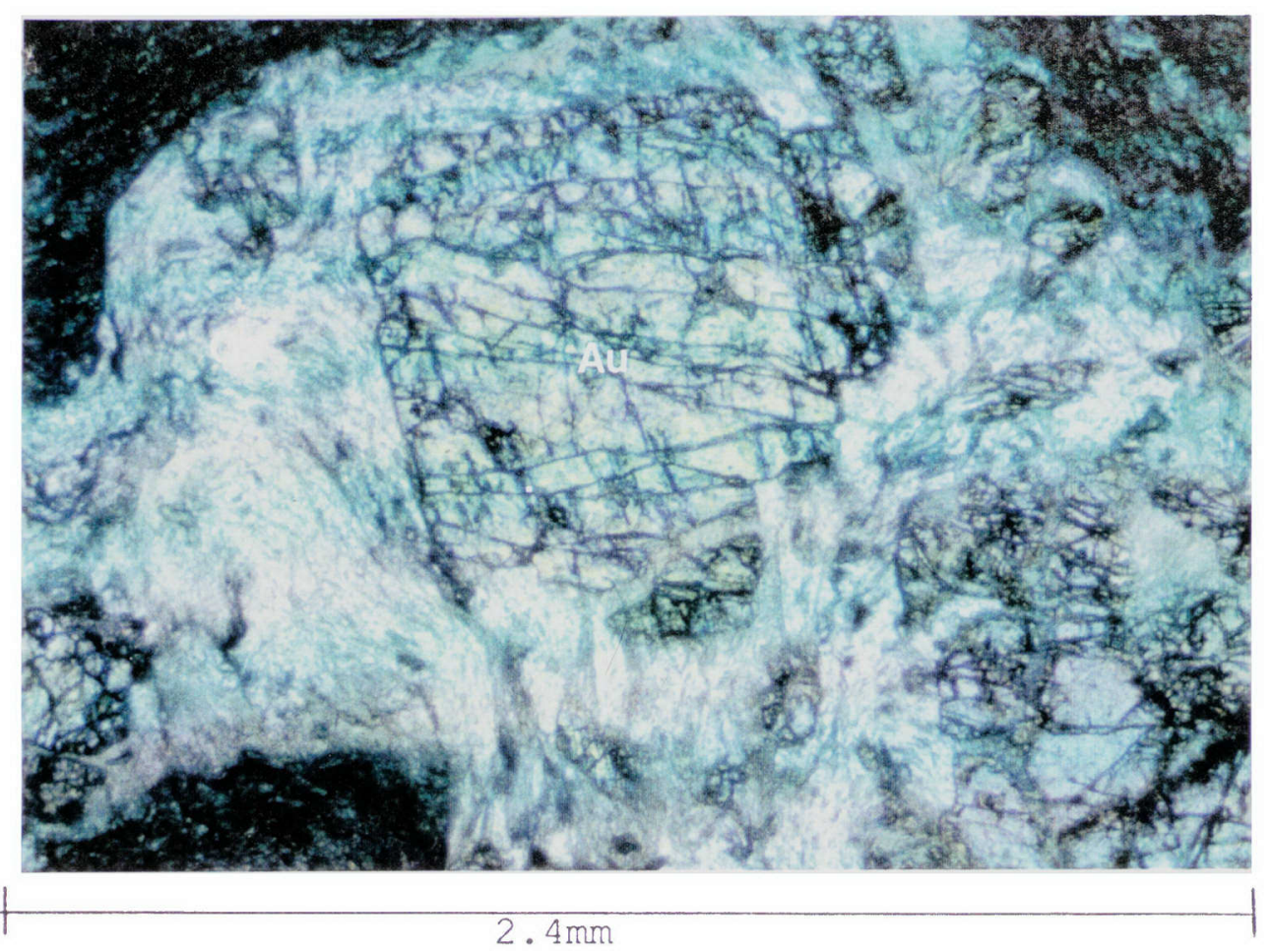

Eigure 2-2. Photomicrograph (plane light) of sample 83-187 (Hicotea Schist). The relict igneous augite (Au) showing original retained igneous terture and augite is surrounded by quartz $(Q z)$ and albite. 
Pumpeliyite is present in sample 83-191a, where it occurs as prismatic needles in radiating sheaf-like aggregates. Figure $2-3$ shows amygdules filled by pumpellyite grains. Pumpellyite is present in one thin section and comprises about 10 to $15 \%$ of the specimen.

Sphene is present as a common accessory mineral in about $50 \%$ of the thin sections and is characterized by its very high relief. In most of the thin sections, the sphene is colorless and hypidioblastic. Sphene also occurs as inclusions in albite.

Calcite is the principal constituent mineral of the marble layers, but calcite is also present as a secondary mineral in the other rocks. In the marbles (83-150), calcite shows typical high order, pearl-gray interference color and forms aggregates with polysynthetic twinning, and polygonal texture. Calcite is also found in veins and pods.

Some schistose rocks $(84-185,84-20)$ have relatively few ferromagnesian minerals and may be metamorphosed volcanogenic sediments or lava flows.

\section{Texture}

The rocks of the Hicotea unit are very fine grained (0.05-0.07 mm) and in some rocks original igneous porphyritic textures are still present. The relict grains are also often 
pseudomorphed by metamorphic chlorite, epidote, quartz and albite.

Schistosity is formed in most of the rocks by preferred orientation of phyllosilicates and matted, elongate actinolite aggregates. In some specimens, schistosity is also defined by the alignment of Na-amphibole (glaucophane) . The layering mentioned earlier makes up compositional alternations in some rocks (83-139, 83-185, 83-187, 83-191a) and is usually parallel (Figure 2-4).

The Hicotea schists show compositional layering in some cases of sedimentary origin and in others metamorphic. Layers of quartz, chlorite, white mica and albite are often detached and form pods (83-139). In some cases, such layering may reflect the original banding of sedimentary tuffaceous rocks.

In several specimens, the foliation is refolded by subsequent deformation to produce microfolds or crenulations accompanied by metamorphic concentration of quartz in the hinges of microfolds and phyllosilicate minerals in the limbs (specimen 83-187). Micro-folds are often outlined by bands of segregated opaque minerals with chlorite and mica (Figure $2-5)$. 


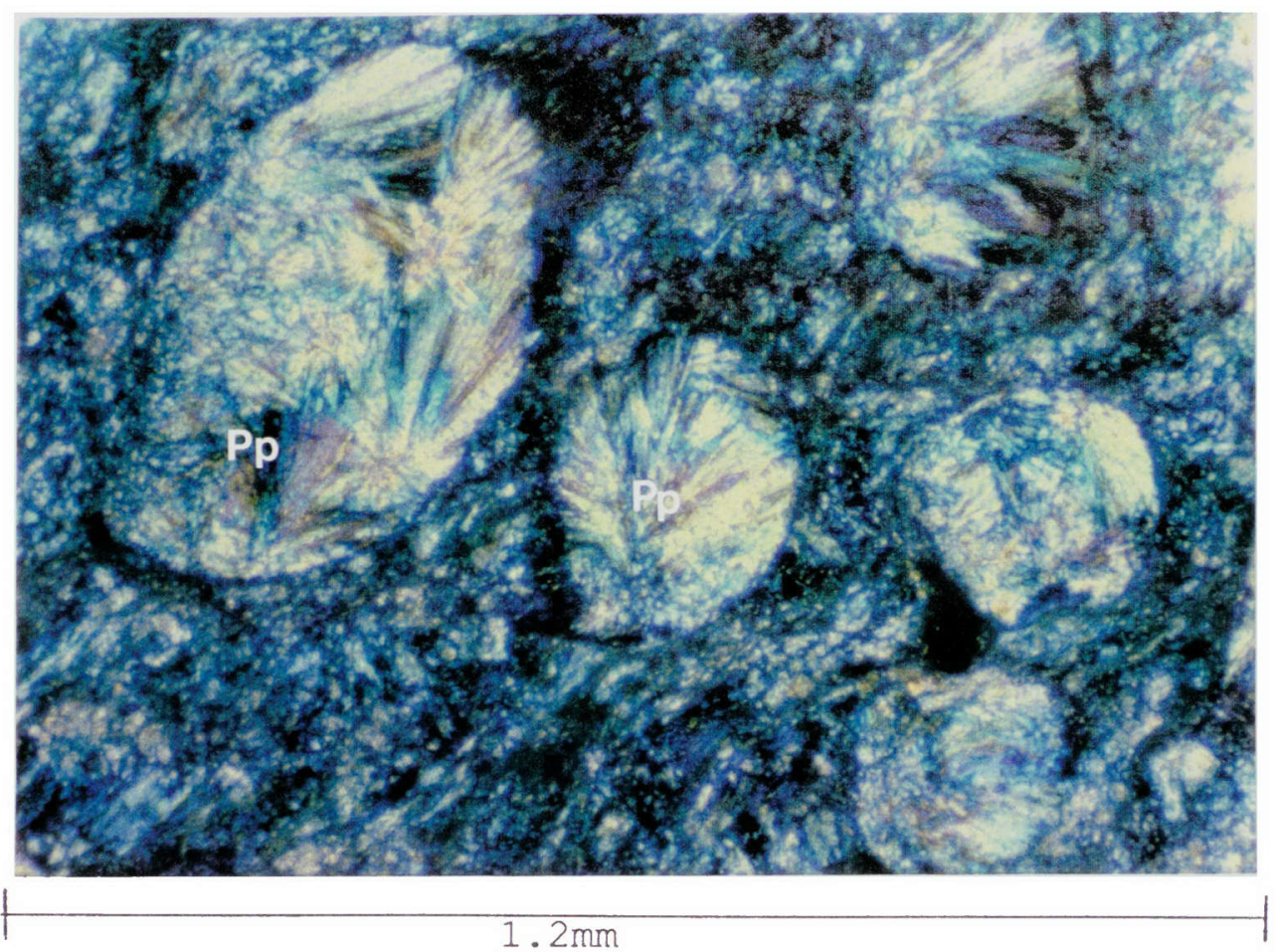

Figure 2-3. Photomicrograph (cross polar) of sample 83191 a (Hicotea Schist). The view shows of amygdules radiating bundles of green acicular crystals of pumpeliyite $(\mathrm{Pp})$. 


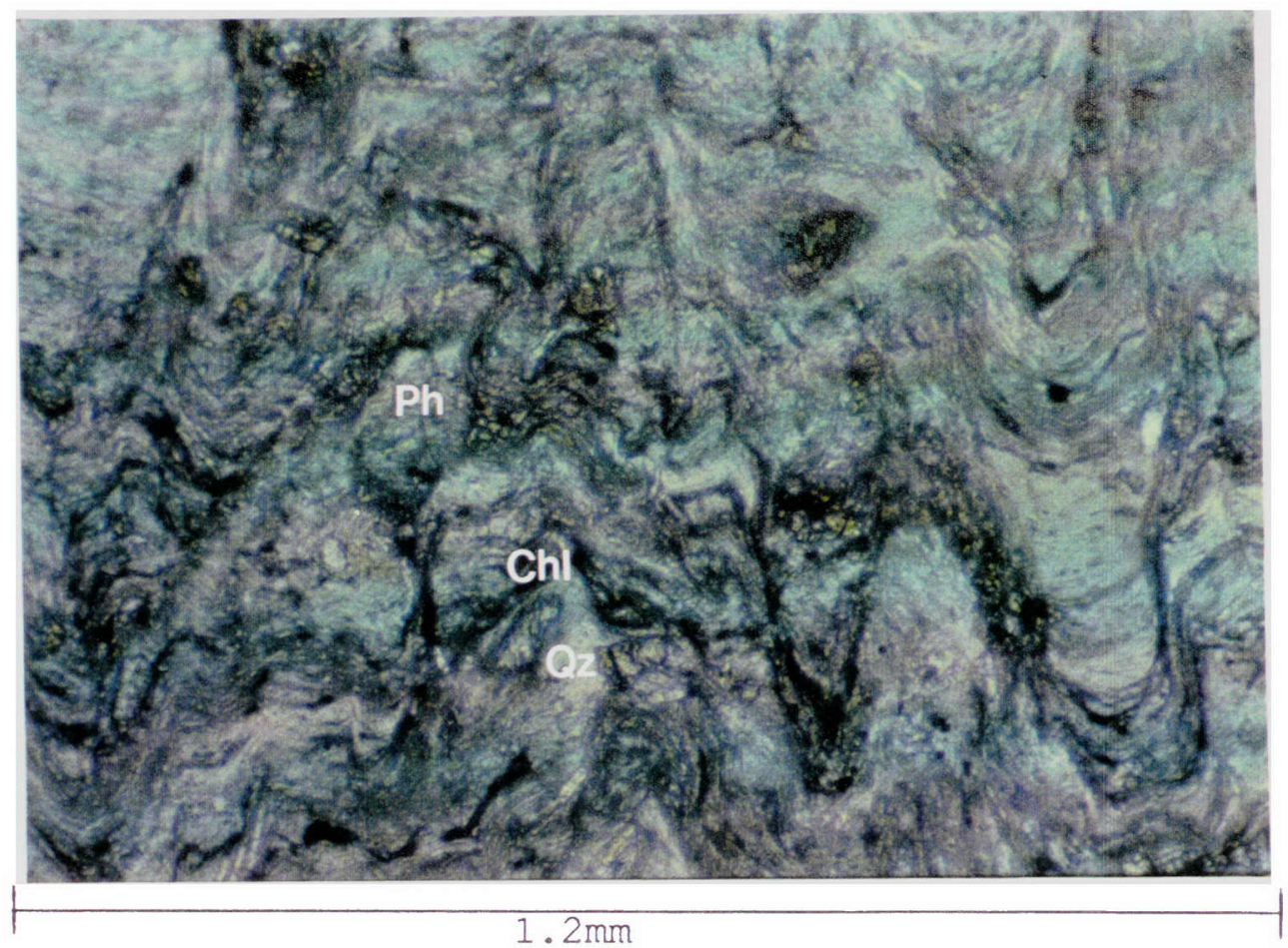

Figure 2-4. Photomicrograph (plane light) of sample 83-187 (Hicotea Schist). Segregation of layers rich in quartz (Qz) and albite (low relief and light grey) with layers rich in white mica (phengite=Ph) and chlorite (Chl, high relief, green and black). 


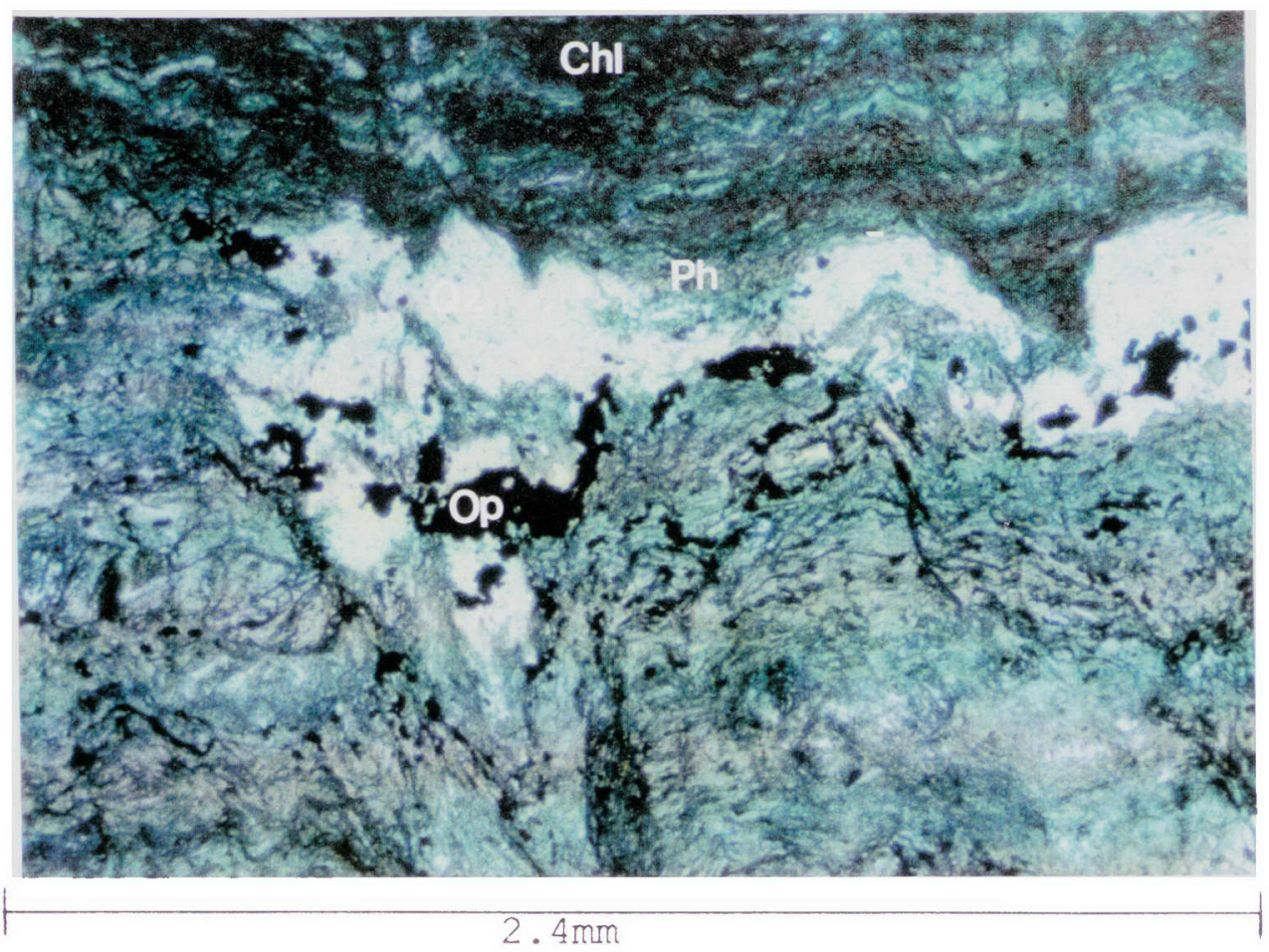

Eigure 2-5. Photomicrograph (plane light) of sample 83-187 (Hicotea schist). Eolds are outlined by bands of segregated opaque minerals (Op) with chlorite (Chl) and phengite (Eh, dark green). Light cclur and low relief is quartz $(\mathrm{Qz})$. 


\section{PUERCA GORDA SCHISTS}

\section{Field Occurrence}

The Puerca Gorda schists are similar to the Hicotea Schists in composition and texture. The Puerca Gorda Schists are distinguished from the Hicotea Schists in that they lack the marble layers and pervasive fracturing which are important characteristics of the Hicotea Schists. The Puerca Gorda Schists also contain occasional decimeter to meter bands of felsic, leucocratic schists which are composed of quartz, albite, tremolite and white mica.

\section{Mineralogy}

Mineral assemblages of the Puerca Gorda Schist represent blueschist facies near the transition to greenschist facies. Some rocks are greenschists some are blueschists. However, most of the greenschists lack the diagnostic mineral assemblage for greenschist facies and are associated with rocks of the epidote-blueschist facies (Evans, 1990). Examples of lawsonite blueschist and epidote blueschist occur. Co-existing actinolite and glaucophane are also observed in some rocks.

Some of the rocks, like the Hicotea schist retain relicts of pre-existing igneous pyroxene (83-142b). The relict phenocrysts are augite not diopside. 
The typical mineral assemblages of Puerca Gorda Schists are listed in table 2-1. Individual minerals are described below:

Quartz is present in fine grained $(0.06-0.15 \mathrm{~mm})$, xenoblastic grains and also shows mosaic texture in some quartzofeldspathic rocks.

Chlorite, epidote and white mica (phengite) in the Puerca Gorda Schists are as described for the Hicotea Schists.

Albite is present in 30 to $35 \%$ of the samples and associated with quartz, chlorite, mica and Na-amphibole. Albites are hypidioblastic crystals. Albites are also present as porphyroblast.

Na-amphiboles are fine grained (.06-.09mm) and are present as both glaucophane and crossite. Zoning in Na-amphibole is observed in sample 84-77. In sample 84-77 actinolite rims glaucophane (Figure 2-6).

Actinolite is present in minor amounts as elongate, acicular and idioblastic crystals and in the sample mentioned above as rims on glaucophane.

Lawsonite is present in one-third of the Puerca Gorda rocks (83-168a, 84-9, 84-78a). Within individual samples of the Puerca Gorda Schists it is more abundant than in the Hicotea schists. It is associated with Na-amphibole in some rocks, 
but in 84-9 it is present as porphyroblasts without glaucophane. Some lawsonite crystals are idioblastic.

Pumpellyite is present in specimens 84-13 and 84-77 where amygdules contain radiating pumpellyite aggregate which show green to yellowish brown pleochroism.

Calcite is present in veins in two thin sections (83$142 \mathrm{~b}, 84-9)$ as a secondary mineral, but is not common in the Puerca Gorda Schists.

Sphene is present as an accessory mineral, and as inclusions in albite. It displays very high relief and subidioblastic shape.

The relative abundances of the minerals in the Puerca Gorda schists are similar to those if the Hicotea Schist.

\section{Textures}

The textures of the Puerca Gorda Schist are very similar to the Hicotea schist. In some rocks, original igneous porphyritic textures are present. Generally, crystals are xenoblastic to hypidioblastic with some rare idioblastic crystals of lawsonite. Some samples retain relicts of preexisting igneous phenocrysts (pyroxene). A schistosity is defined by common crenulation of white mica and chlorite but very weakly developed. Specimen 84-77 shows crenulation of the cleavage. Epitaxial overgrowth of pyroxene with Na- 
amphibole and then with actinolite is observed in rock 84-77 (Eigure 2-7). 


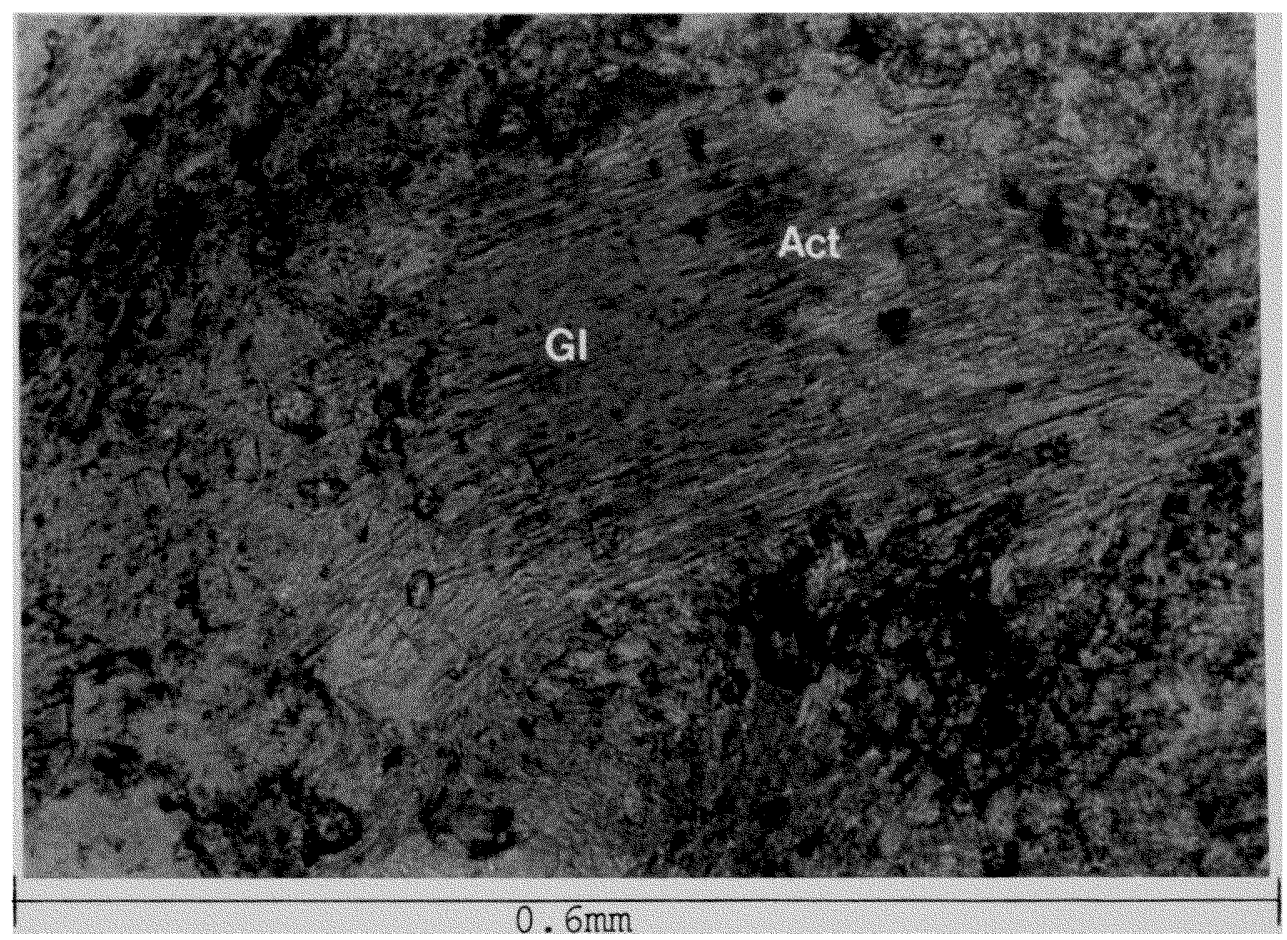

Figure 2-6. Photomicrograph (plane light) of sample 84-77 (Puerca Gorda Schist). Actinolite (Act) rims glaucophane (GI) indicating the rock may have experienced a decrease in pressure or temperature. 


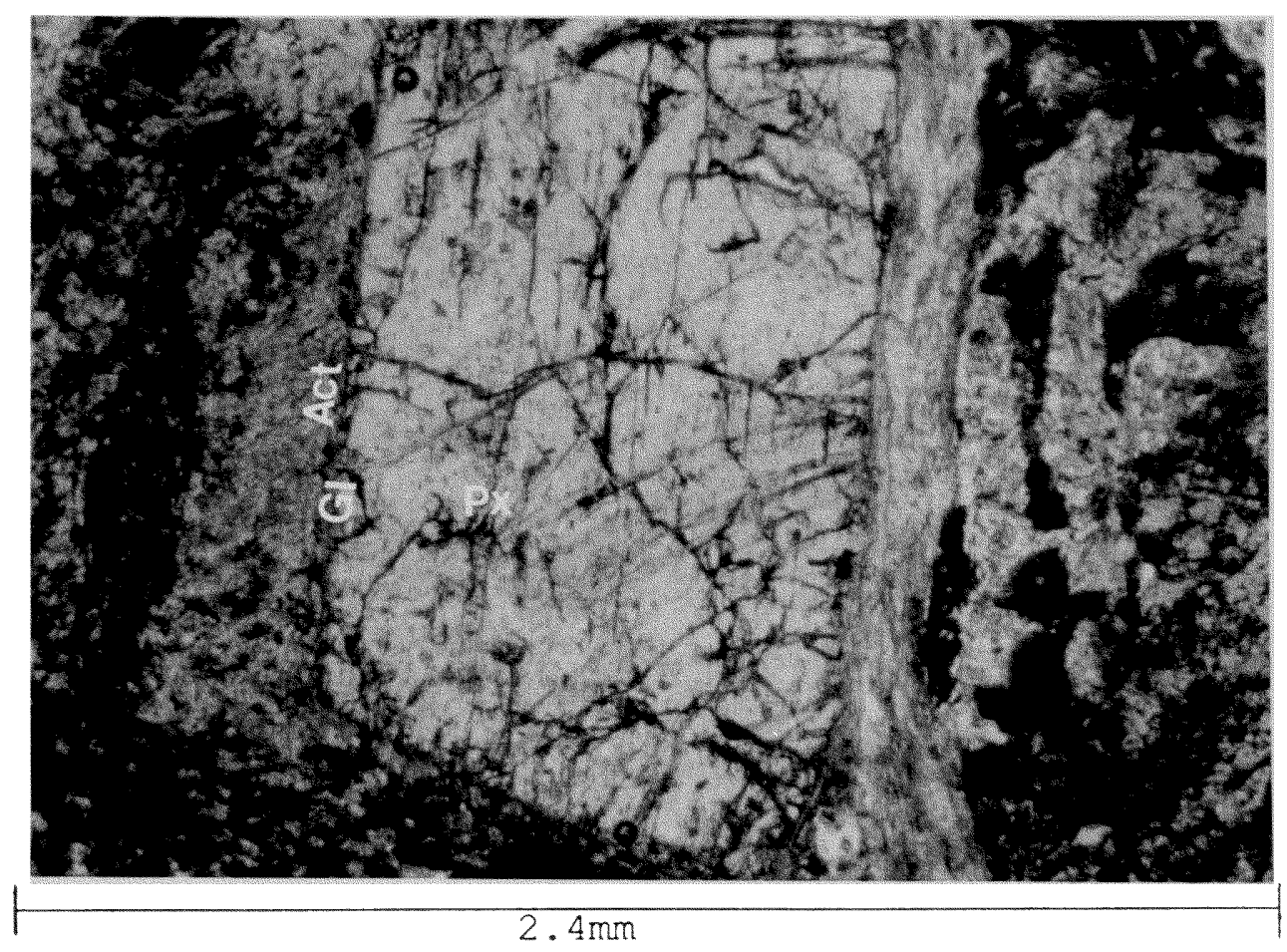

Figure 2-7. Photomicrograph (plane light) of sample 84-77 (Puerca Gorda Schist). Epitaxial overgrowth actinolite over glaucophane (light color around the large grain) and pyroxene ( $\mathrm{Px}$, at the center, high relief), where actinolite (Act) rims glaucophane (Gl). 


\section{JAGUA CLARA MELANGE}

\section{Field Occurrence}

The outcrops of the Jagua Clara melange lie within the Puerca Gorda Schist. The melange consists of a variety of different types of blocks, which are listed in table 2-2, of coarse grained blueschists and eclogites. The blocks range from 0.25 to more than $20 \mathrm{~m}$ in diameter. The blocks are generally ellipsoidal in shape with variable axial ratios (Draper \& Nagle, 1991). Many blocks are covered in a dual concentric layer or rind, consisting of a coarse-grained actinolite inner layer, surrounded by an outer layer of fine grained actinolite-chlorite (Draper and Nagle, 1991).

\section{Mineralogy}

The most common mineral assemblages in the Jagua Clara melanges are shown in table $2-1$.

There are at least two groups of mineral assemblages which represent two distinct grades of metamorphism. Both are high pressure but one is lower temperature (epidote, Naamphiboles) than the other (omphacite, hornblende). The most abundant minerals in the Jagua Clara melange are quartz, albite, chlorite, epidote, white mica, garnet and glaucophane. Hornblende and omphacite are also present in some blocks 
Coarse grained quartzofeldspathic blocks (84-138, 83-87) are also present. In some blocks (83-171i) white mica is present consisting as much as $40 \%$ of an individual thin section. Rutile and sphene are present as accessory minerals.

Individual minerals are described below:

Quartz is present in quartzofeldspathic blocks, usually fine grained ( .1 mm), xenoblastic and showing mosaic texture. Quartz is also present in other blocks.

Epidote and Clinozoisite are fine to medium grained $(0.15-0.25 \mathrm{~mm})$ and subidioblastic to idioblastic. Clinozoisite is distinguished from epidote by lower order birefringence, biaxial positive interference figure and lack of pleochroism. First-order gray and yellow interference colors are and replaced by anomalous blue gray or yellowlemon color in both clinozoisite and epidote.

Garnet is identified by its high relief, and isotropic optics. Garnet crystals may be as much as $6 \mathrm{~cm}$ in diameter and present as idioblastic and sub-idioblastic porphyroblasts. Some of the garnets have cores crowded with inclusions of quartz, chlorite, white mica, rutile and/or sphene (Figure 2-8). In places garnets are replaced partially by chlorite, especially around the rims. The 
texture of the rims (Figure 2-8) is also different from the core suggesting the garnets may be compositionally banded.

White micas are present as phengite and fuchsite. They are idioblastic and 0.15 to $0.25 \mathrm{~mm}$ long. Chromium bearing mica (fuchsite) is identified by its bright green pleochroism and emerald green color. Phengite shows straight (mottled) extinction and pale green color. No paragonite has been observed.

Hornblende is present in some blocks and identified by its strong green pleochroism and two cleavages (Figure 2-9). Grains are xenoblastic to hypidioblastic and $0.2 \mathrm{~mm}$ to $0.3 \mathrm{~mm}$ in length.

Omphacite is identified by its pale green color, biaxial positive interference figure and higher $2 \mathrm{~V}\left(\sim 60^{\circ}\right)$ than augite. It is xenoblastic to hypidioblastic and the average size of the grains is about $0.3 \mathrm{~mm}$. The birefringence was used to estimate its composition, which is omphacite to diopsidic jadeite (52-85 Molecular $\frac{\circ}{0} \mathrm{NaAl}$.

Rutile is present as subidoblastic to idioblastic crystals $0.2 \mathrm{~mm}$ to $0.3 \mathrm{~mm}$ in size. It is distinguished by its deep red-brown color, the extreme relief and extreme birefringence.

The mineral assemblages vary considerably from block to block. The mineralogy of some blocks is within type $\mathrm{C}$ 
eclogite facies, since garnet, phengite and omphacite are all present. Some samples have classic glaucophane schist facies assemblages of lawsonite + glaucophane (83-87, 83-171d). Some rocks contain unidentified opaque minerals (84-136). In block 84-136, hornblende is present with garnet.

\section{Texture}

The high-grade blocks are coarsely crystallized and have poorly defined schistosity. Where garnet and omphacite predominate (84-136), the garnets form porphyroblasts and the omphacite groundmass is granoblastic. Many garnets have cores that are crowded with small inclusions, whereas the rims are relatively free of, or lack inclusions. The cores appear to be preferentially replaced by chlorite in some cases. Hornblende is also present in sample 84-136 (Figure 2-9). The coarse-grained, garnet-omphacite-bearing rocks are overprinted by glaucophane, albite, chlorite, epidote, actinolite, white mica or lawsonite. In some rocks glaucophane replaces omphacite (84-100).

As will be discussed in the section on conditions of metamorphism, some of these rocks may have formed in the eclogite facies and been subsequently recrystallized in the blueschist facies so that original garnet and omphacite was partially or entirely replaced by chlorite and/or glaucophane. 


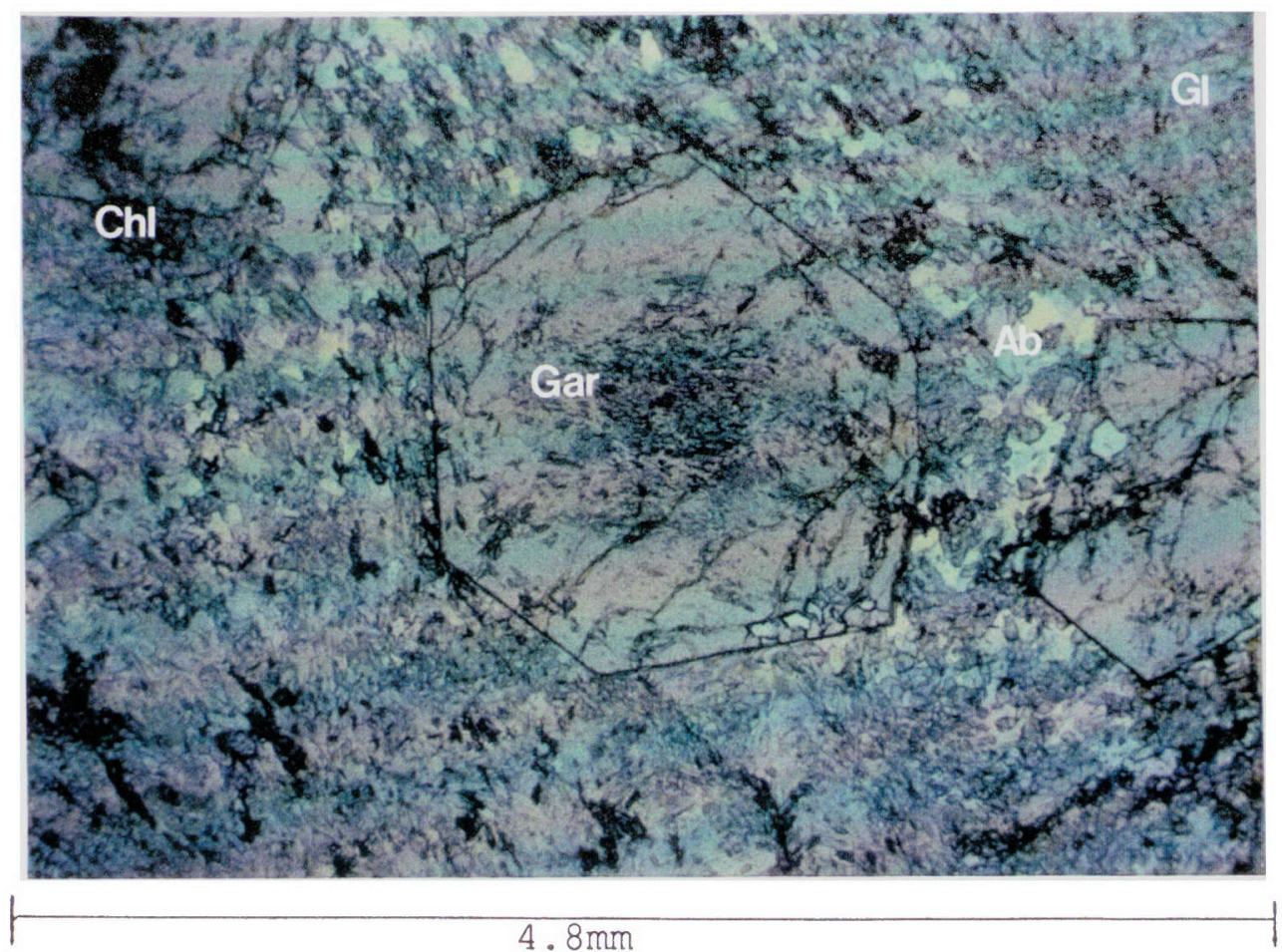

Figure 2-8. Photomicrograph (plane light) of sample 83142d (Jagua Clara melange). Idioblastic garnets (Gar) have cores crowded with inclusions of chlorite, quartz, rutile and white mica, whereas the rims have relatively few inclusions. The surrounding matrix is primarily glaucophane (GI) with some albite ( $\mathrm{Ab}$, white) and chlorite (Chl, dark color). 


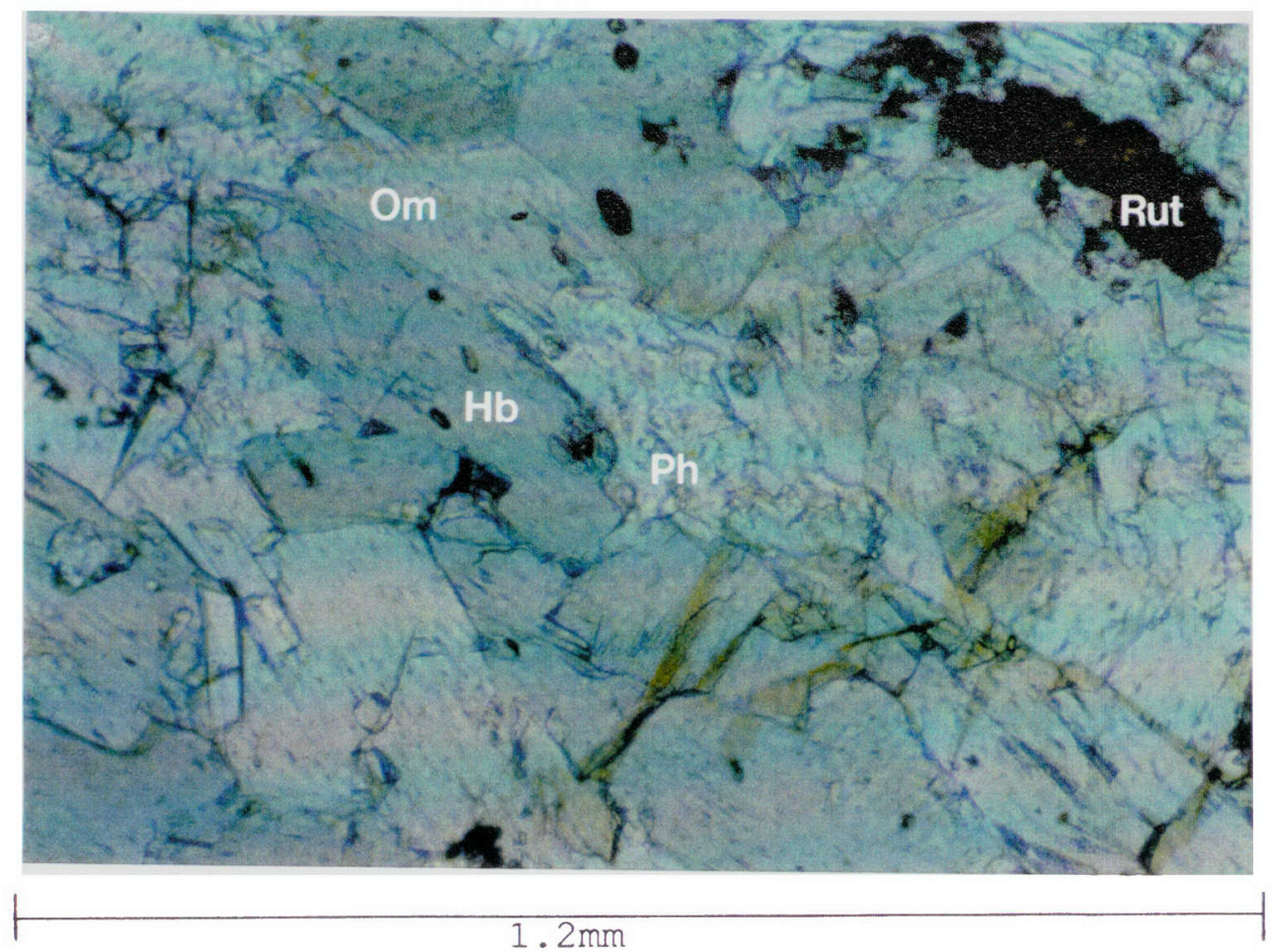

Figure 2-9. Photomicrograph (plane light) of sample 84-136 (Jagua Clara melange). Equilibrium texture of hornblende (Hb, medium green) and omphacite (Om, pale green). Rutile (Rut) in the upper right is dark and gold to black and the pale colored mineral nearly in the center is phengite ( $\mathrm{Ph}$ ). 
In some blocks of Jagua Clara melange (83-142d, 84-16, 84-100) glaucophane rims hornblende (Eigure 2-10), indicating the blocks may have experienced a decrease in temperature at high pressure or an increase in pressure and decrease in temperature.

All the blocks have poorly defined schistosity except block 84-100 which has a well defined schistosity. schistosity in block $84-100$ is defined by white mica (fuchsite, phengite), actinolite, and Na-amphibole; rutile grains oriented parallel to the foliation.

Compositional banding is found in some of the eclogitesand garnet blueschists of the Jagua Clara Melange. 


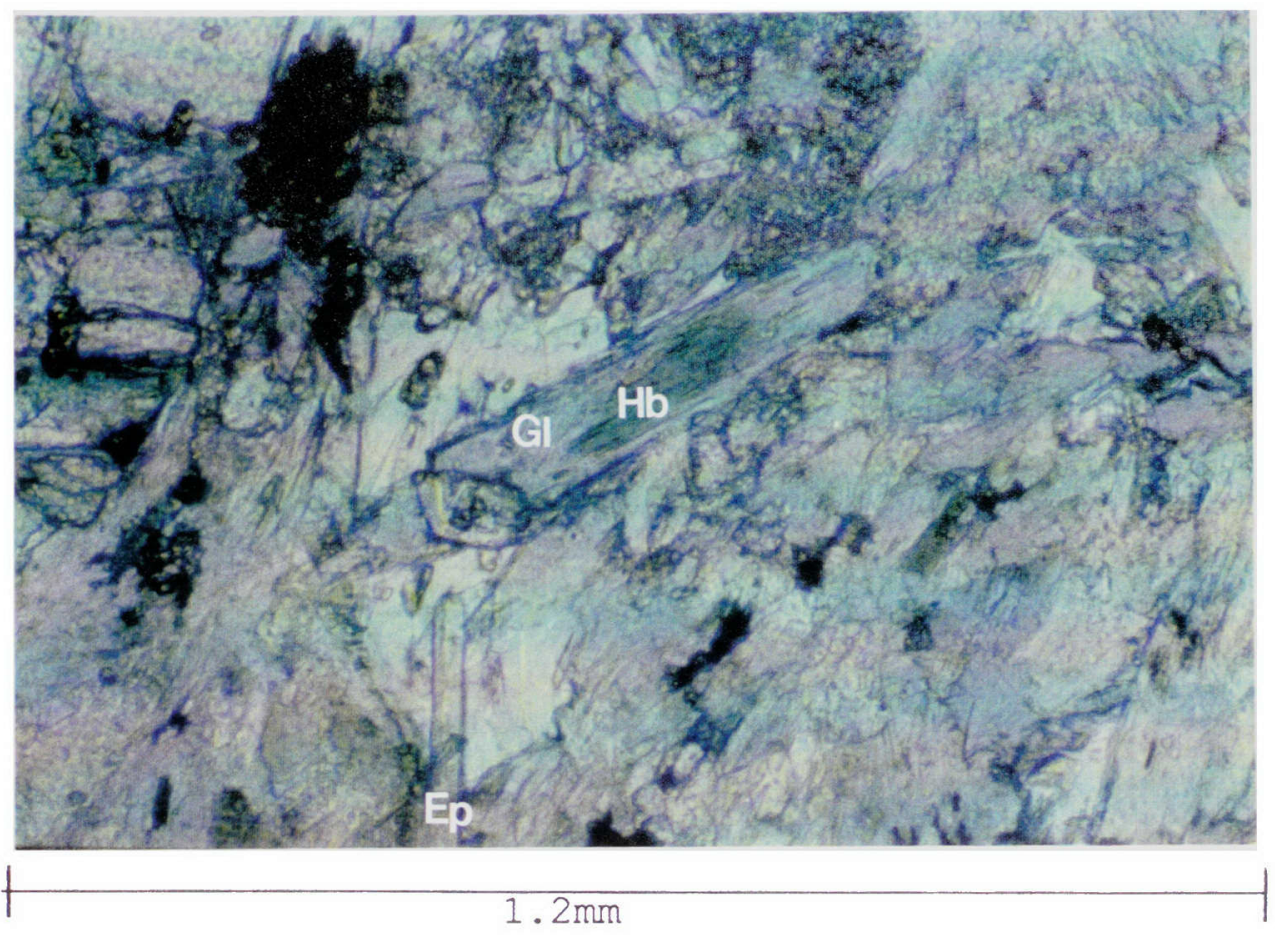

Figure 2-10. Photomicrograph (plane light) of sample 84-16 (Jagua Clara melange) where glaucophane (GI) rims hornblende ( $\mathrm{Hb}$ ) indicating the block may have experienced a decrease in temperature at high pressure. Also present: quartz (light color) and epidote (Ep, idioblastic acicular grain left of center at bottom). 


\section{ARROYO SABANA MELANGE}

\section{Field Occurrence}

The Arroyo Sabana melange occurs as isolated bodies to the north and east of the Jagua Clara melange, and may also occur within the outcrop of the Jagua Clara melange (Draper and Nagle, 1991). This unit contains greenschist, amphibolite, marble and quartzo-feldspathic blocks in addition to fine-grained blueschists. Three types of blocks are studied (table 2-2). The unit differs from Jagua Clara melange principally in that blocks contains little or no garnet in the blueschist blocks. Also, in contrast to the Jagua Clara melange, there is no evidence of an early eclogite facies metamorphism preceding the blueschist metamorphism.

\section{Mineralogy}

Mineral assemblages vary from block to block. Blocks consist of garnetiferous-blueschists, albite epidote amphibolites, epidote blueschists and lawsonite blueschists.

Typical mineral assemblages are shown in table 2-1. A few individual few minerals are described below:

Hornblende is present in albite-epidote-amphibolite blocks (Figure 2-11). It is identified by its green color, 
green pleochroism and two directions of cleavage. Crystals are $0.3 \mathrm{~mm}$ to $0.5 \mathrm{~mm}$ in size and xenoblastic in shape.

Tremolite is present as acicular, fibrous and subidioblastic crystals and $0.3 \mathrm{~mm}$ to $0.6 \mathrm{~mm}$ in size. It is identified by its first to second order interference colors and diamond or wedge shaped cross section, larger $2 \mathrm{~V}$ and larger extinction angle than actinolite.

Talc displays typical third order birefringence color, straight (mottled) extinction. It is present in 83-144 (Figure 2-12) as very fine grained $(\sim 0.001 \mathrm{~mm})$. It is distinguished from mica by its association with tremolite and its grain size.

Garnets are present as idioblastic porphyroblasts in blocks of garnetiferous blueschist. Garnets vary widely in size from $.1 \mathrm{~mm}$ to $3 \mathrm{~mm}$ in diameter. Unlike blocks of the Jagua Clara melange, garnets are not present in most of the blocks. In 84-82 garnet is partially replaced by chlorite. Garnet cores are more crowded by inclusions than the rims. Inclusions are chlorite, sphene and white mica.

Glaucophane is not overprinted with hornblende or omphacite except in one rock (84-12), where glaucophane has partially replaced the original pyroxene. Within the same block glaucophane is surrounded by mica in an apparent replacement texture. This could indicate that glaucophane formed earlier 
than the mica and they are not in equilibrium. In another glaucophane grain from the same rock, the core is Mg-rich and rim is Fe-rich.

The properties and associations of epidote, chlorite and lawsonite are similar to those of the same minerals in the Jagua Clara melange.

\section{Texture}

Textures suggesting overprinting of comparatively higher-grade blocks by lower-grade blueschist-facies metamorphism are rare in the Arroyo sabana melange. Glaucophane is associated with lawsonite in block 84-76, where the subidioblastic lawsonite is present as porphyroblasts.

Blocks 84-12 and 84-78b are the only blocks that show a schistosity, and it is defined by common alignment of white mica, and green and blue amphiboles.

\section{SUMMARY OF PETROGRAPHY}

The Puerca Gorda Schist and Hicotea Schist are similar in overall texture, composition and mineralogy. Both units exhibit metamorphism in lawsonite-blueschist and in epidoteblueschist facies near the transition to greenschist facies. Mineral assemblages are similar in both schists which are mostly lawsonite blueschist and epidote-blueschist facies 
assemblages. Some of the rocks from the Puerca Gorda Schist and most of the rocks of the Hicotea schist retain relicts of pre-existing igneous pyroxene. Schistosity is mainly defined in the coherent schists by chlorite-, white mica-, and quartz-rich domains parallel to the schistosity. The Puerca Gorda Schist is distinguished from the Hicotea Schist in that it lacks the marble layers and the pervasive fracturing.

Both melange units have lawsonite and epidote blueschist. Garnetiferous blueschist is more common in the Jagua Clara melange. Omphacite is not found in Arroyo Sabana melange. Amphibolite blocks are rare but unique to the Arroyo Sabana melange, whereas hornblende-eclogite blocks are unique to the Jagua Clara melange.

Garnet porphyroblasts are very common in the Jagua Clara melange, whereas they are scarce in blocks of the Arroyo Sabana melange. These porphyroblasts of the Jagua Clara melange are generally much larger in diameter compared than those in the Arroyo Sabana melange. Blocks of the Jagua Clara melange show clear evidence of overprinting whereas the Arroyo Sabana melange blocks show very little evidence of overprinting of earlier high temperature assemblages. 


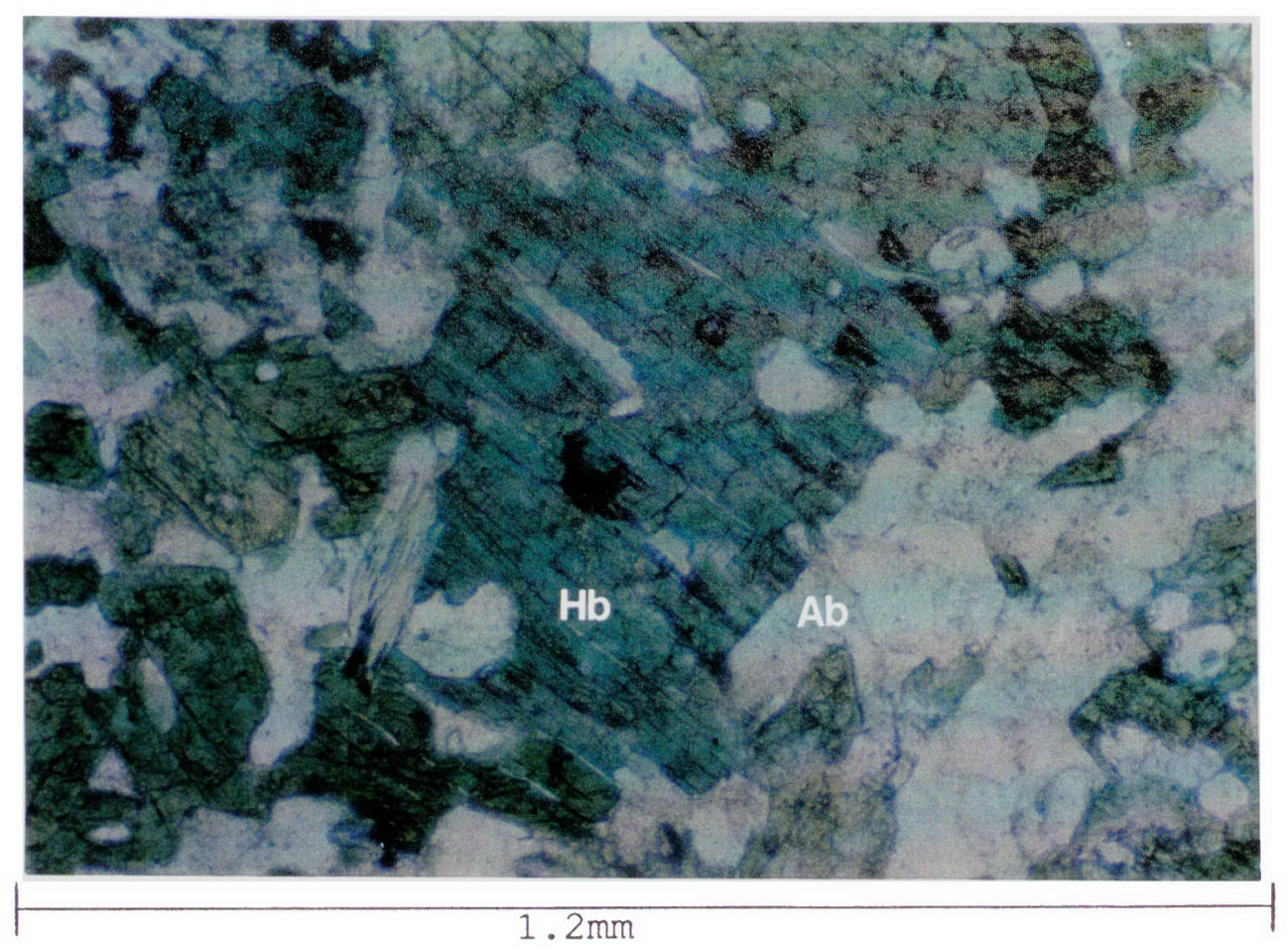

Figure 2-11. Photomicrograph (plane light) of sample 84-69 (Arroyo Sabana melange). Hornblende (Hb, green) and albite ( $\mathrm{Ab}$, white) representing the high-pressure/high-temperature of albite epidote amphibolite blocks of Arroyo Sabana melange. 


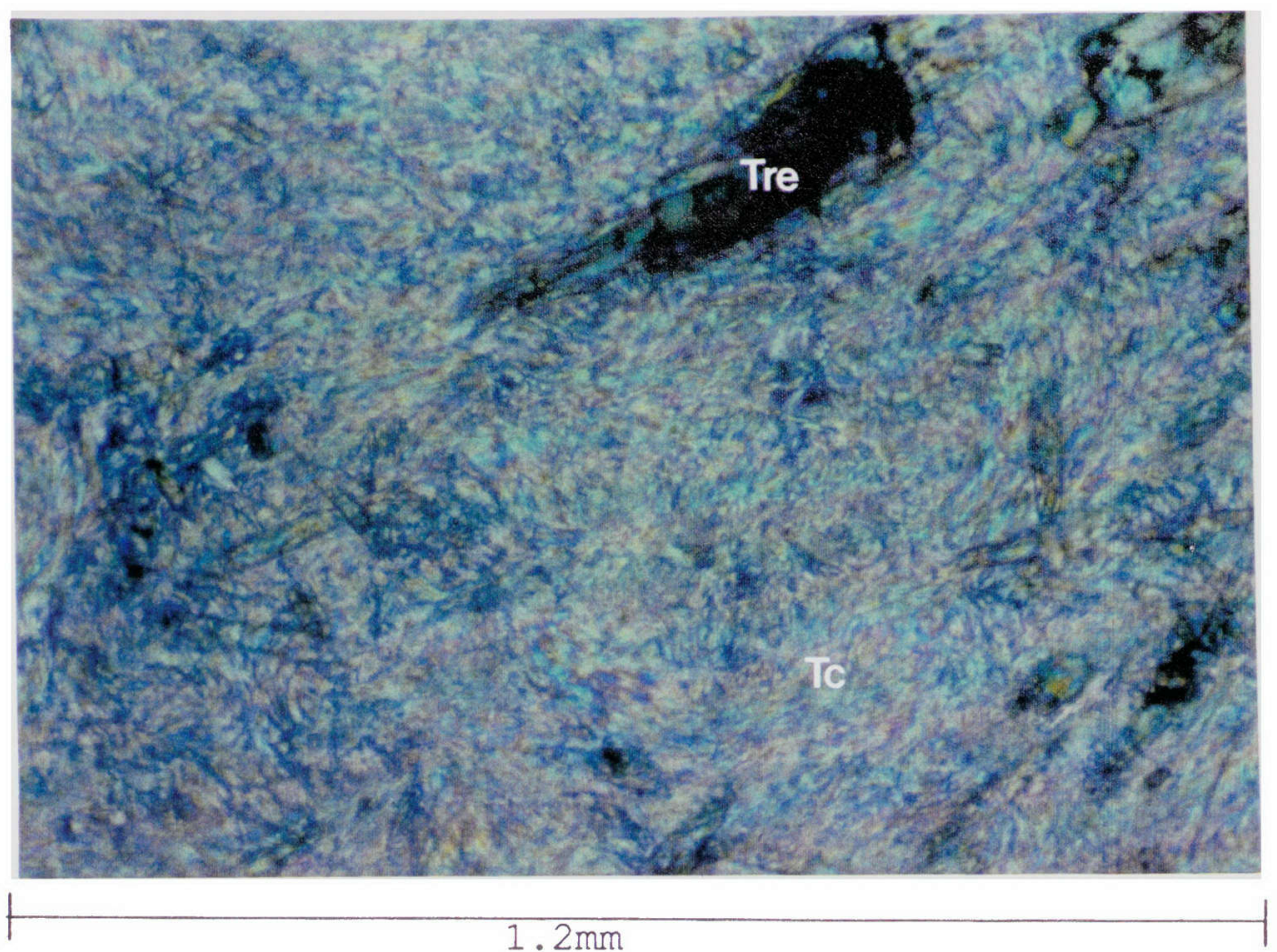

Figure 2-12. Photomicrograph (crossed polar) of sample 83144 (Arroyo Sabana melange). This is a part of a rind where serpentine has been metasomatically altered to talc (TC, high birefringence) and chromium-rich tremolite (Tre, dark green). 


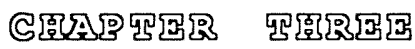

CONDITIONS OF METAMORPHISM 


\section{CONDITIONS OF METAMORPHISM}

Different metamorphic facies and mineral equilibria will be used to help determine the conditions of metamorphism of the four different units of RSJ Complex. Rocks from the coherent schists mostly belong to epidote-blueschist facies with some rocks representing lawsonite-blueschist facies. Blocks from the melange units represent a variety of metamorphic facies: lawsonite-blueschist, epidote-blueschist, albite-epidote-amphibolite, and eclogite facies.

Various assemblages of minerals that reach equilibrium during metamorphism within a specific range of $\mathrm{P}-\mathrm{T}$ conditions represent the same metamorphic facies (Fyfe and Turner, 1966). Each facies can be related to physical conditions under which they have formed. Different facies are recognized covering the entire spectrum of possible metamorphic conditions. As a result of experimental studies, and field observations the approximate pressure and temperatures of the facies can now be estimated as shown in Figure 3-1. This figure will be use to determine conditions of metamorphism of RSJ rocks belonging to different metamorphic facies. The defining mineral assemblages for metabasites of the different metamorphic facies are listed in table 3-1. 


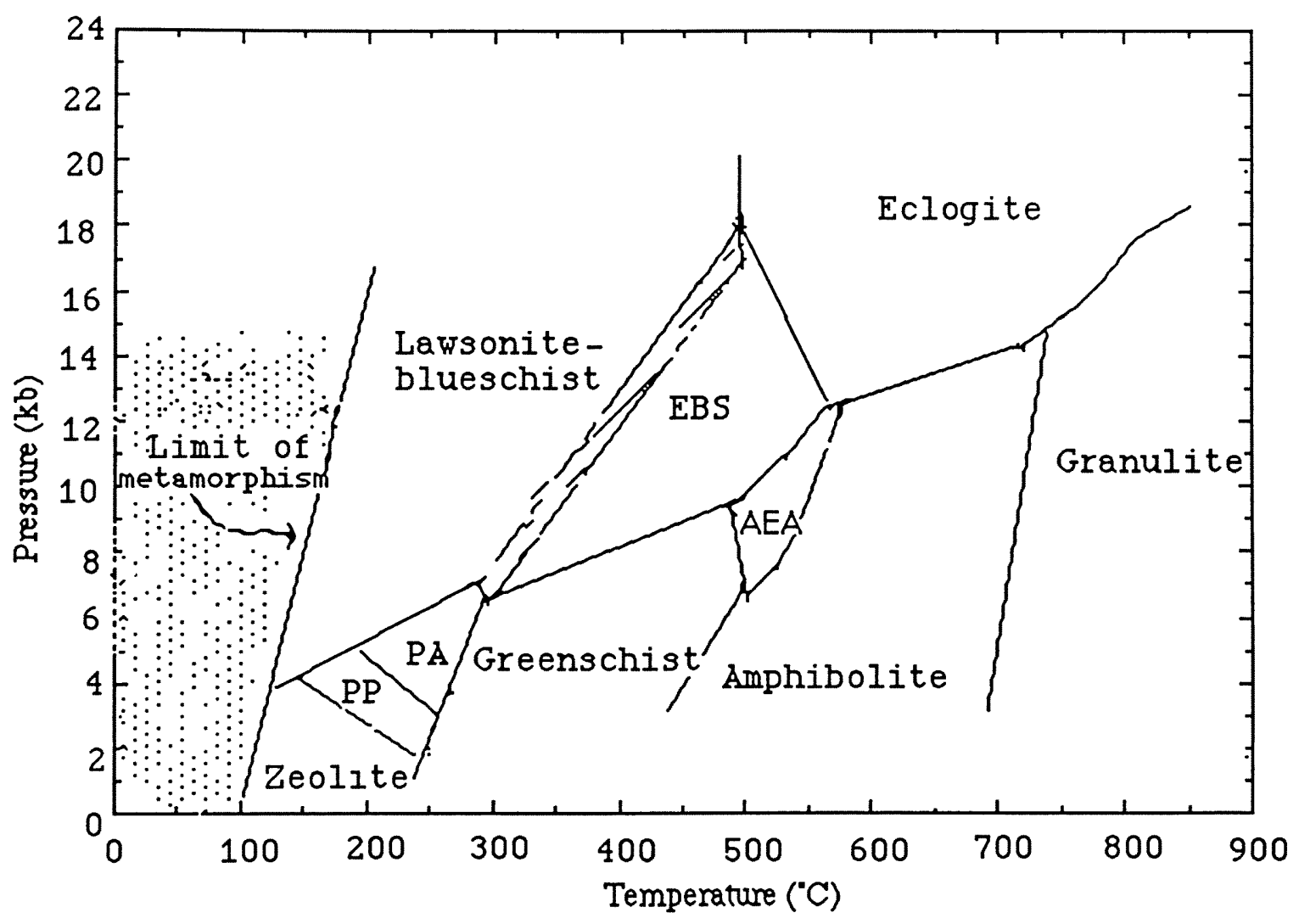

Figure 3-1. Approximate pressure and temperatures under which mineral facies form. $P A=$ pumpellyite-actinolite, EBS=epidote-blueschist paragenesis, pp=prehnitepumppellyite, $\mathrm{AEA}=a$ lbite-epidote-amphibolite: (modified from Evans, 1990). 
TABLE 3-1: Mineral assemblages for Metabasites of different facies (after Evans, 1990).

\begin{tabular}{|l|l|}
\hline FACIES & STABLEPARAGENESES \\
\hline Epidote-blueschist & $\mathrm{Na-amph}+\mathrm{Ep}+\mathrm{Qz}+\mathrm{H} 2 \mathrm{O}$ \\
\hline Lawsonite-blueschist & $\mathrm{Na}$-amph $+\mathrm{Law}$ \\
\hline Eclogite & Omph $+\mathrm{Gar}+\mathrm{Qz}+\mathrm{H} 2 \mathrm{O}$ \\
\hline Pumpellyite-actinolite & Pump $+\mathrm{Act}+\mathrm{Chl}+\mathrm{Ab}+\mathrm{Qz}+\mathrm{H} 2 \mathrm{O}$ \\
\hline Greenschist & $\mathrm{Ab}+\mathrm{Chl}+\mathrm{Act}+\mathrm{Ep}+\mathrm{Qz}+\mathrm{H} 2 \mathrm{O}$ \\
\hline Amphibolite & $\mathrm{Plag}+$ Act/Hornd $+\mathrm{H} 2 \mathrm{O}$ \\
\hline Albite-Epidote-Amphibolite & Ab + Act/Hornd + Ep; absent: \\
& Na-amph, Plag, Greenschist paragenesis \\
\hline
\end{tabular}


Estimates of the temperature and pressure of the four different units of the Rio san Juan Complex will be made using mineral assemblages. Mineral equilibria at facies boundaries have received a great deal of attention in the literature, for example, $\mathrm{Gl}+\mathrm{LW}=\mathrm{Ep}+\mathrm{Ch} I+\mathrm{Ab}+\mathrm{Qz}+\mathrm{H}_{2} \mathrm{O}$. In addition to metamorphic facies, specific mineral equilibria which are not facies boundaries will also be used, for example, Albite + Jadeite = Quartz.

Many minerals in the different units have impurities, in particular the minerals glaucophane, chlorite, epidote, pumpellyite, actinolite, garnet, and omphacite. Reactions involving impure phases occur at different temperatures or pressures than reactions for pure end-member compositions. In some cases, facies boundaries are also shifted because of the impurities in the minerals. Much of the experimental work on the reactions which will be discussed below involved pure phases. In a few cases the affect of impurities has also been investigated, e.g. omphacite, allowing better estimates of pressure and temperature if probe analysis are available. Lacking precise measurements of the impurities and/or experimental work on the effects of impurities, additional error in the $\mathrm{P}-\mathrm{T}$ estimates for the rocks is introduced by the shifts in $\mathrm{P}-\mathrm{T}$ position of reactions involving impure phases. Thus, a rock containing a mineral assemblage consisting of all the minerals in a reaction, need not lie precisely on a univariant reaction curve because the 
impurities make the reaction divariant or multivariant. The impurities allow the rock to have equilibrated over a range of pressure and temperature. The effects of mineral composition on specific equilibria will be discussed later.

\section{Pressure and Temperature of Metamorphic Facies}

The metamorphic facies and their relative conditions of formation are now fairly well established (Figure 3-1). Each facies is recognized by a characteristic assemblage of minerals in rocks of a particular composition (Table 3-1 for metabasites). Under extreme conditions of metamorphism at both high pressure and moderate to high temperature, rocks of basaltic composition recrystallize to eclogite. The temperature of eclogites may be as low as $500^{\circ} \mathrm{C}$ (low grade type C eclogites of New Caledonia), where they are associated with blueschists (Yardley, 1989). Phase equilibria do not provide very good temperature indicators for eclogites, but geothermometry based on Fe-Mg cation exchange between garnet and clinopyroxene (Ellis and Green, 1979) indicates temperatures of $600-750^{\circ} \mathrm{C}$ for type $\mathrm{B}$ eclogites (Yardley, 1989). The actual pressure at which eclogites form is controversial, but all agree that eclogites require pressure higher than $7 \mathrm{~kb}$. The absence of plagioclase sets a quantitative lower pressure limit of eclogites (Newton, 1986). 
The blueschist facies has major boundaries with parageneses belonging to the eclogite, albite-epidoteamphibolite (AEA), pumpellyite-actinolite (PA), and greenschist facies. There is no mutual boundary between the blueschist and amphibolite facies parageneses (Evans, 1990). Available thermobarometry indicates many blueschists equilibrated in the range of $250-450^{\circ} \mathrm{C}$ (Essene, 1989) while others attained $500^{\circ} \mathrm{C}$ (Koons, 1986). Pressure typically varies from 5 to $12 \mathrm{~kb}$ and some blueschists may have attained as much as $12-16 \mathrm{~kb}$ in rocks transitional to the eclogite facies (Koons, 1986). These results suggest that the blueschist/eclogite facies boundary is nearer $15 \mathrm{~kb}$ rather than $10 \mathrm{~kb}$ (Essene, 1989). Evans (1990) calculate the boundary line to be nearly vertical rather than horizontal, so temperature is more important than pressure. The boundary between epidote-blueschist and AEA facies varies from $\sim 7 \mathrm{~kb}$ at $450^{\circ} \mathrm{C}$ to $\sim 14 \mathrm{~kb}$ at $550^{\circ} \mathrm{C}$ and the boundary between lawsonite-blueschist and pumpellyite-actinolite facies varies from $\sim 5 \mathrm{~kb}$ at $200^{\circ} \mathrm{C}$ to $\sim 7 \mathrm{~kb}$ at $275^{\circ} \mathrm{C}$ (Figure $3-1$ ).

Blueschist mineral assemblages are stable over a wide range of temperature, but it is possible to separate the lower-temperature lawsonite blueschists from the highertemperature epidote blueschists. A variety of reactions relate the mineral assemblages of metabasites in greenschist facies to those in lawsonite-blueschist facies (Yardley, 1989; Brothers and Yokoyama, 1982), but due to the 
redefinition of blueschist facies (Evans, 1990) these reactions are either boundaries between the lawsoniteblueschist and the epidote-blueschist facies or they are metastable reactions. The boundary between lawsonite and epidote blueschists varies from $\sim 7 \mathrm{~kb}$ at $275^{\circ} \mathrm{C}$ to $18 \mathrm{~kb}$ at $475^{\circ} \mathrm{C}$, and is defined in part by reaction 1 which will be discussed in the next section. The conditions of the transition zone between the epidote-blueschist and greenschist facies are not well defined, but Brown (1977) has estimated a pressure of around $7-8 \mathrm{~kb}$ at a temperature around $400^{\circ} \mathrm{C}$. This transition is defined in part by reaction 6 which is explained later in the text. There is a small boundary between epidote-blueschist and pumpellyite-actinolite facies at about $300^{\circ} \mathrm{C}$ and $7 \mathrm{~kb}$ (Evans, 1990) (Eigure 3-1).

The low temperature boundary of greenschist facies is well defined by the breakdown of pumpellyite (Figure 3-1) (Schiffman and Liou, 1980, 1983). Changes in metabasites within the greenschist and amphibolite facies are a result of continuous reactions. Thermobarometry of the greenschist facies reveals temperatures of $300-500^{\circ} \mathrm{C}$, but the $\mathrm{P} / \mathrm{T}$ limit relative to the pumpellyite and blueschist facies remains quantitatively ill-defined (Essene, 1989). Based on the placement of the albite-epidote-amphibolite facies, the greenschist/amphibolite boundary may vary between $450^{\circ} \mathrm{C}$ and $550^{\circ} \mathrm{C}$. 
The section which follows covers the metamorphic conditions of the two coherent schist units together. The succeeding section discusses the conditions of various blocks in the two melange units.

\section{HICOTEA AND PUERCA GORDA SCHISTS}

\section{Metamorphic Facies}

The Hicotea and the Puerca Gorda units primarily represent epidote-blueschist facies with minor transitions to greenschist and lawsonite-blueschist facies. Na-amphiboles are absent in some of the samples from the Hicotea and the Puerca Gorda Schists. Although many samples contain the high pressure glaucophane and/or lawsonite, these minerals are not present in all rocks. Rocks lacking the high pressure minerals petrographically resemble greenschists (Table 3-1).

\section{Pressure and Temperature}

The temperature and pressure of the coherent schists are constrained by a number of mineral equilibria. Temperatures above $550^{\circ} \mathrm{C}$ are unlikely in these coherent bodies in view of the presence of chlorite instead of garnet (Avigad et al., 1991), presence of blue amphiboles, and absence of albiteepidote-amphibolite facies minerals.

The presence in the coherent schists of some rocks with mineral assemblages on either side of reaction 1 , below 
constrains the schists to metamorphism close to this reaction, provided the schists were not metamorphosed under a large temperature or pressure gradient.

$$
\mathrm{Gl}+\mathrm{LW}=\mathrm{EP}+\mathrm{ChI}+\mathrm{Ab}+\mathrm{Qz}+\mathrm{H}_{2} \mathrm{O}
$$

Brown and Ghent (1983) have estimated the approximate conditions of equilibrium (Figure 3-2) by using field observations and a combination of low albite-jadeite-quartz barometry of Newton and Smith (1967) and oxygen isotope thermometry (Figure 3-2). This is the lawsonite-blueschist to epidote-blueschist transition for rocks containing abundant glaucophane. The assemblage Na-amphibole (Gl) + lawsonite (Lw) occurs in some rocks of the Hicotea schists and the Puerca Gorda Schists: three samples from the Hicotea Schist, and one from the Puerca Gorda Schists (Table 2-1). Albite, chlorite and actinolite are present in other rocks of the coherent schists: one sample from the Hicotea Schist, and four from the Puerca Gorda Schists (Table 2-1). These two assemblages indicate conditions of metamorphism on both the low and high temperature sides of reaction 1 . The presence of impurities in glaucophane of rocks of the Hicotea and Puerca Gorda Schists introduces error in reaction 1 of about $\pm 2 \mathrm{~kb}$, causing a shift in the facies boundary (Evans, 1990).

There is no complete greenschist facies assemblage in the Hicotea Schist (Tables 2-1, 3-1), but one sample (83-198) from the Puerca Gorda Schist has a mineral assemblage that 
occurs in both epidote-blueschist and greenschist facies. This sample may have impurities in glaucophane and epidote which might shift the facies boundary from epidote-blueschist to greenschist-facies. The presence of greenschist facieslike assemblages (i.e. without blueschist-facies minerals) probably indicates that these rocks were metamorphosed at a lower temperature and/or higher pressure than the greenschist facies $\left(<325^{\circ} \mathrm{C}\right.$ at $7 \mathrm{~kb}$ to $<500^{\circ} \mathrm{C}$ at $\left.10 \mathrm{~kb}\right)$. Reaction 6 , discussed later, is related to this facies boundary.

Holland (1979) proposed a barometer based on the reaction

$$
L w+A b=\text { Zoisite + Paragonite }+Q z+\text { Water }
$$

which he extrapolated from experiments and calculated based on thermodynamic data derived from experiments on equilibria among other phases in the system $\mathrm{Na}_{2} \mathrm{O}-\mathrm{Al}_{2} \mathrm{O}_{3}-\mathrm{SiO}_{2}-\mathrm{H}_{2} \mathrm{O}$. Heinrich and Althaus (1980) report experimental reversal of the same equilibrium and give results which are coincident within uncertainty limits $\left( \pm 15^{\circ} \mathrm{C}\right)$ with Holland's calculation. The left side of reaction 2 occurs in some rocks of the Puerca Gorda Schists (samples 84-9, 83-168a). The conditions of metamorphism represent the low temperature side of the reaction, a maximum temperature of $\sim 400^{\circ} \mathrm{C}$ (Figure $3-2$ ).

Nitsch (1971) investigated the reaction

$$
\text { Pumpellyite }+\mathrm{Chl}+\mathrm{Qz}=\mathrm{Ep}+\text { Actinolite }+\mathrm{H}_{2} \mathrm{O} \text {. }
$$


Using natural materials, he bracketed the equilibrium at $345^{\circ}$ and $435^{\circ} \mathrm{C}$ at $7 \mathrm{~kb}$. Nitsch (1971) also showed that, with natural minerals the reaction progressed to the right at about $360^{\circ} \mathrm{C}$ at $6 \mathrm{~kb}$ (Figure $3-2$ ). The paragenesis chloritepumpellyite-quartz corresponding to the left side of the reaction occurs only at pressures greater than $2.5 \pm 1 \mathrm{~kb}$ and "it is stable at $7 \mathrm{~kb}$ in the strongly pressure-dependent temperature range $260 \pm 20^{\circ} \mathrm{C}$ to $370 \pm 20^{\circ} \mathrm{C} "$ (Nitsch 1971).

Epidote from the North Cascades, Washington, associated with actinolite, chlorite and quartz but not pumpellyite, lies on the high-temperature side of reaction 3 (Brown and O'Neil, 1982). Recalculated oxygen isotope temperature from the same locality (Taylor and Coleman, 1968) are $345^{\circ}, 360^{\circ}$, and $365^{\circ} \mathrm{C}$. Within error these temperatures are consistent with the experimental results of Nitsch (1971).

The assemblage epidote + actinolite occurs in some of the Hicotea and Puerca Gorda Schists and indicates conditions of metamorphism on the high temperature side of reaction 3 , which is above $\sim 275^{\circ} \mathrm{C}$ at $7 \mathrm{~kb}$ (Figure 3-2). Pumpellyite + Chl $+Q z$ is present in one sample (83-191a) in the Hicotea Schists indicating the other side of the reaction, below $275^{\circ} \mathrm{C}$. One sample (83-191a) from the Hicotea schist contains the mineral assemblages on both sides of reaction 3 . This may be because impurities in pumpellyite, epidote, chlorite and actinolite widen the range of temperature and/or pressure 
at which all of the minerals in the reaction can coexist in equilibrium. It is suggested that the metamorphism of these schists occurred at temperature and pressures close to reaction 3 .

Cloos (1985) suggested that at temperatures below $200{ }^{\circ} \mathrm{C}$ to $250^{\circ} \mathrm{C}$, thermal diffusion is insufficient to produce coarse grained minerals and schistose rocks. The coherent schists have many schistose rocks, although the grains are not coarse.

Pressure is a more difficult variable to determine, but it is very important in that it allows a depth of burial to be estimated. The pressure range for the blueschist unit is constrained by the presence of lawsonite in some rocks, by glaucophane and by albite.

Many estimates of the pressure of blueschist metamorphism have been based on the reaction (Holland, 1980):

$$
\text { albite = jadeite + quartz }
$$

This equilibrium represents the upper pressure stability limit of albite. Albite is present in most of the rocks of the Hicotea and Puerca Gorda Schists indicating these rocks equilibrated on the lower pressure side of the reaction. In the Hicotea Schist, lawsonite-bearing rocks do not contain albite, but without omphacite + quartz or jadeite + quartz there is no evidence that metamorphism was not still on the 
low-pressure, high-temperature side of the reaction 4 . Therefore, the pressure of coherent schists was probably less than $10 \mathrm{~kb}$ at $375^{\circ} \mathrm{C}$ and less than $6 \mathrm{~kb}$ at $250^{\circ} \mathrm{C}$ (Figure 3-2).

Relatively Fe-poor glaucophane requires a minimum pressure of $4 \mathrm{~kb} P \mathrm{H}_{2} \mathrm{O}$ and is probably not stable over $550^{\circ} \mathrm{C}$ (Maresch, 1977). These figures are from unreversed naturalglaucophane-breakdown experiments, so the temperatures are maxima and the pressures are minima for near end-member glaucophane. The maximum glaucophane stability field according to Maresch (1977) is shown in Figures 3-2 - 3-4 (as line 5). Between 350 to $550^{\circ} \mathrm{C}$ the maximum stability of $\mathrm{Mg}-$ rich glaucophane is dependent on temperature and pressure, varying from $4 \mathrm{~kb}$ at $350^{\circ} \mathrm{C}$ to $10 \mathrm{~kb}$ at $550^{\circ} \mathrm{C}$, but when glaucophane is impure, the stability field widens. The presence of fairly magnesium-rich glaucophane in some samples of Hicotea and Puerca Gorda schists suggests a minimum pressure of approximately $4 \mathrm{~kb}$. Crossite would have a higher maximum temperature and lower minimum pressure than Mg-rich glaucophane, with pressure shift on the order of $4 \mathrm{~kb}$ and temperature shift of as much as $150^{\circ} \mathrm{C}$ for crossite with $50 \%$ Mg riebeckite end member (Evans, 1990).

Another reaction which helps constrain the pressure of some blueschist blocks is:

$$
\mathrm{Gl}+\text { Clinozoisite }+\mathrm{Qz}+\mathrm{H}_{2} \mathrm{O}=\text { Tremolite }+\mathrm{Chl}+\mathrm{Ab}
$$


Reaction 6 was bracketed experimentally by Maruyama et al. (1986) using natural glaucophane, tremolite and clinozoisite. Because these phases contain minor impurities, the experimentally determined position of reaction 6 is displaced from its position for pure mineral composition designated as reaction 6' (Eigure 3-2, 3-3, and 3-4). "A 1.5 to $2.5 \mathrm{~kb}$ uncertainty is created by the unknown structural state of albite in the reactions products" (Evans, 1990). Evans estimates the position of $6^{\prime}$ at $300^{\circ} \mathrm{C}$ and just under $9 \mathrm{~kb}$, and at $350^{\circ} \mathrm{C}$ and $\sim 11.5 \mathrm{~kb}$; this is within error, about 2.5 $\mathrm{kb}$ higher at $350^{\circ} \mathrm{C}$ than Maruyama et al.(1986). Evans (1990) calculated a different slope and position for this reaction based on thermodynamic data. Evans (1990) also calculated the effects of impurities in glaucophane varying to ferroglaucophane and crossite which indicate an additional pressure uncertainty for the reaction of about 2-3 $\mathrm{kb}$. Minimum pressures for reaction 6, allowing for impurities, are: $6 \mathrm{~kb}$ at $300^{\circ} \mathrm{C}$ and $\sim 8 \mathrm{~kb}$ at $500^{\circ} \mathrm{C}$ according to Evans (1990, Figure 8) for his Na-amphibole compositions 5 and 6 which are both crossite; $7 \mathrm{~kb}$ at $300^{\circ} \mathrm{C}$ and $\sim 10-11 \mathrm{~kb}$ at $500^{\circ} \mathrm{C}$ for his compositions 3 and 4 which are both on the crossiteglaucophane border.

All the specimens from the Hicotea schist are on the high-pressure side of reaction 6, some with fairly Mg-rich glaucophane, which gives a low-pressure limit for the rocks of about $7 \mathrm{~kb}$. Most of the Puerca Gorda Schists also fall on 
the high-pressure side of the reaction, but one sample contains minerals from both sides of the reaction. This sample has impurities in the minerals: glaucophane, actinolite, chlorite and epidote, which may cause shifts in the epidote-blueschist-facies/greenschist-facies transition (Figure 8 in Evans, 1990). With impurities in the minerals the reaction becomes trivariant rather than univariant, thereby allowing all phases to coexist in equilibrium over a range of pressure and temperature (Figure 11 in Owen, 1989).

In sample 84-77 (Puerca Gorda Schist), actinolite rims glaucophane (Figure 2-6) indicating the rock may have experienced a decrease in pressure.

The equilibria from reactions 1-6, thus, approximately constrains the metamorphic condition of Hicotea and Puerca Gorda Schists to fall within the range $\mathrm{T}=250-400^{\circ} \mathrm{C}$ and $\mathrm{P}=7-12$ $\mathrm{kb}$, but likely to be close to $300^{\circ} \mathrm{C}$ at $7-8 \mathrm{~kb}$ (Figure 3-2). 


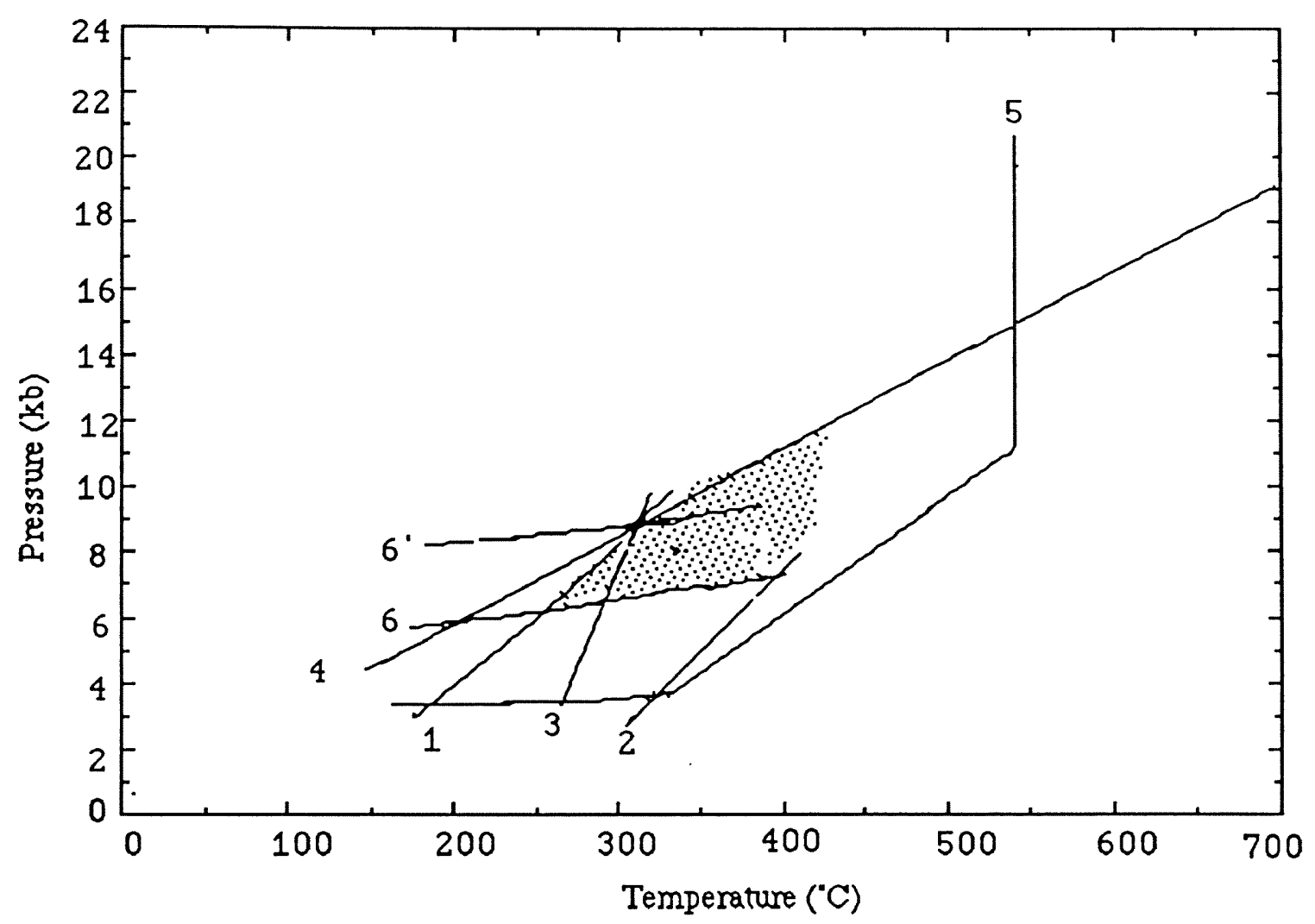

Figure 3-2. P-T conditions of Hicotea and Puerca Gorda Schists. (1) Glau + Law $=\mathrm{Ep}+\mathrm{Chl}+\mathrm{Ab}+\mathrm{Qz}+\mathrm{H}_{2} \mathrm{O}$ (Brown and Ghent, 1983): (2) Law + Alb = Zoisite + Paragonite $+\mathrm{Qz}+\mathrm{H}_{2} \mathrm{O}$ (Holland, 1979): (3) $\mathrm{Pp}+\mathrm{Chl}$ $\mathrm{Qz}=\mathrm{Ep}+\mathrm{Act}+\mathrm{H}_{2} \mathrm{O}$ (Nakajima, 1977): (4) $\mathrm{Ab}=$ jadeite $+Q z$ (Holland, 1980): (5) Glaucodhane stabilitv field according to Maresch (1977): (6) and (6') Gl + Clino $+\mathrm{Qz}+\mathrm{H}_{2} \mathrm{O}=$ Tremolite $+\mathrm{Chl}+\mathrm{Ab}$ (Maruyama et al. 1986). $\left(6^{\prime}\right)=$ impure phases. $\left(6^{\prime}\right)=$ pure phases. 


\section{JAGUA CLARA AND ARROYO SABANA MELANGE}

The Jagua Clara and Arroyo Sabana melanges contain different blocks of various compositions, textures, and mineral assemblages. Because the blocks may have originated from diverse locations they may have undergone different conditions of metamorphism.

\section{Metamorphic Facies}

Various blocks of the Jagua Clara melange have undergone metamorphic conditions within the lawsonite-blueschist, epidote-blueschist, eclogite facies, and albite-epidoteamphibolite facies. The epidote-blueschist facies is much more commonly represented than the lawsonite-blueschist facies of the Jagua Clara melange. The highest grade in the Jagua Clara melange is either albite-epidote-amphibolite facies or type C eclogite facies. Overprinting of albiteepidote-amphibolite by epidote-blueschist facies (Figure 210), and eclogite by epidote-blueschist facies is observed in the Jagua Clara melange (84-16). The greatest temperature change represented by overprinting within one block is from albite-epidote-amphibolite or type $\mathrm{C}$ eclogite to epidoteblueschist facies, a change in temperature of $\sim 150^{\circ} \mathrm{C}$.

The Arroyo Sabana melange is represented by the same metamorphic facies as the Jagua Clara melange, except it does not have eclogite-facies blocks. Blocks metamorphosed within 
albite-epidote-amphibolite-facies are more abundant in the Arroyo Sabana melange than the Jagua Clara melange. The highest grade in the Arroyo Sabana melange is albite-epidoteamphibolite-facies (sample 84-69). Overprinting of glaucophane over hornblende is not evident in the Arroyo Sabana melange, but garnets are partially replaced by chlorite in some blocks. Within the epidote-blueschist facies some blocks of the Arroyo Sabana melange were metamorphosed to a lower temperature, chlorite-bearing part of that facies.

\section{Pressure and Temperature}

The presence of the high-pressure minerals: jadeitic pyroxene (omphacite), glaucophane-crossite, and lawsonite, in some of the blocks of the melanges, suggests a low geothermal gradient (high pressure, low temperature). Within this low geothermal gradient, the blocks show a considerable range of temperatures and an uncertain but probably lesser range of pressures. The pressure and temperature conditions of metamorphism of different blocks of the Jagua Clara and Arroyo Sabana melanges are shown in Table 3-2 and Figures 33, 3-4. Certain equilibria constrain the conditions of metamorphism of all of the blocks; these are discussed first. The metamorphism of each type of block is then explained.

Nearly all the blocks in both melanges contain glaucophane or crossite. Glaucophane-bearing mineral 
assemblages have a large pressure range. The breakdown of glaucophane given by curve 5 in Figures 3-3 and 3-4 (Maresch, 1977) constrains the metamorphic conditions of the blocks at low pressures and temperatures. Reactions such as glaucophane $=\mathrm{Jd}+$ talc occur at very high pressure $(\sim 31 \mathrm{~kb}$ at $500^{\circ} \mathrm{C}$ : Holland, 1988 ; or $26 \mathrm{~kb}$ at $450^{\circ} \mathrm{C}$ : Carman and Gilbart, 1983; or $\sim 25 \mathrm{~kb}$ at $600^{\circ} \mathrm{C}$ : Boettcher and Wyllie, 1969), and, thus, do not provide tightly constrained upper pressure limits for the RSJC metamorphism.

Albite is present in most of the blocks in the Jagua Clara melange and some in the Arroyo Sabana melange. For these rocks equilibrium 4 provides an upper pressure limit of $15 \mathrm{~kb}$ at $550^{\circ} \mathrm{C}$ or $11 \mathrm{~kb}$ at $400^{\circ} \mathrm{C}$. Blocks which do not contain albite are, therefore, not constrained by reaction 4 , include all of the lawsonite blueschists (Figure 3-3) and those eclogite blocks which are not overprinted.

Garnetiferous blueschist-facies rocks contain garnet instead of chlorite. Temperatures of $500^{\circ} \mathrm{C}$ at $10 \mathrm{~kb}$ and $490^{\circ} \mathrm{C}$ at $14 \mathrm{~kb}$ form the transition (reaction 7) between garnet and chlorite (Avigad et al. 1992). Garnet is stable at higher temperatures and chlorite at lower (Figure 3-3, 34). Because of compositional variation in garnet and chlorite this curve may shift between $\sim 425$ and $\sim 590^{\circ} \mathrm{C}$ at 10 $\mathrm{kb}$ (Avigad et al. 1992). Some of the block types discussed 
below contain garnet, some contain chlorite, and some show replacement of garnet by chlorite.

Lawsonite-blueschist blocks (see table 2-2) are found in both melanges. The lowest temperatures achieved among the blocks of the melanges occurred within these blocks. They contain the mineral assemblage from the lower-temperature side of reaction 1 (Figure 3-3). With the absence of better constraints, the presence of glaucophane limits the upper pressure of metamorphism of these rocks to below 25 (?) $\mathrm{kb}$ (curve 5, Figure 3-3). The 200 to $250^{\circ} \mathrm{C}$ minimum temperature suggested by Cloos (1985) for coarse minerals and to produce schistose rocks may be applied to these rocks.

Blocks which underwent at least one stage of metamorphism within epidote-blueschist facies can be split into four groups: the hornblende-garnet blueschists and glaucophanic eclogites from the Jagua Clara melange, and the glaucophane-bearing albite-epidote-amphibolite and epidote blueschists from the Arroyo Sabana melange.

Hornblende-garnet blueschists: in the hornblende-garnetblueschist blocks of Jagua clara melange (table 2-2) glaucophane rims hornblende, indicating the blocks may have experienced a decrease in temperature at high pressure. Hornblende formed at an earlier time within the AEA facies at a temperature above $\sim 500^{\circ} \mathrm{C}$ and a minimum pressure $7 \mathrm{~kb}$ (Evans, 1990, and Figure 3-5). 
Garnet cores may have grown during this early AEA facies metamorphism. Idioblastic garnets have cores crowded with inclusions, whereas the rims have relatively few inclusions. The garnets also appear to be a stable part of the second stage paragenesis, co-existing with glaucophane + epidote + quartz. This assemblage belongs to the garnet-bearing epidote-blueschist facies above reaction 7 , but between reaction 4 and curve 5 (Figure 3-3). The assemblage, glaucophane + epidote + quartz, corresponds to the high pressure side of reaction 6 . If one adjusts reaction 6 for the impurities in the minerals the minimum pressure of the second stage of metamorphism of these blocks is about $7 \mathrm{~kb}$ (Figure 8, Evans 1990) at $\sim 500^{\circ} \mathrm{C}$ to $\sim 550^{\circ} \mathrm{C}$ (Figure $3-3$ ).

Glaucophanic eclogites: the glaucophanic eclogites within the Jagua Clara melange experienced two stages of metamorphism as indicated by grains with cores of omphacite and rims of glaucophane. During the first stage of metamorphism, these blocks may have achieved the highest temperatures and pressures of any of the blocks, metamorphism in type $C$ eclogite facies (Figure 3-5). The presence of garnet, quartz and jadeitic clinopyroxene (omphacite) in eclogite blocks (Jagua Clara melange), 84-136 and 84-100, indicates the blocks were metamorphosed at a temperature of a least $500^{\circ} \mathrm{C}(\mathrm{Platt}, 1975)$. The temperature could not exceed $700^{\circ} \mathrm{C}$ because sheet silicates and epidote are not stable above that temperature (Platt, 1975) (Figure 3-5). The 
glaucophanic eclogite blocks are overprinted by lower grade epidote-blueschist-facies assemblages. The samples contain epidote + actinolite, the high temperature assemblage of reaction 3, giving these rocks an extreme lower temperature limit of the reaction which is shown in Figure 3-3. The temperature of this second stage of metamorphism is further constrained by reaction 7 due to the pressure of garnet in equilibrium with the second stage assemblage. Pressure is above reaction 6 and curve 5 (Figure 3-3).

Glaucophane-bearing albite-epidote-amphibolite: in contrast to the blocks of the Jagua Clara melange, glaucophane-bearing albite-epidote-amphibolite (Table 2-2) of Arroyo Sabana melange show no textural evidence for disequilibrium between hornblende and glaucophane. This suggests that the blocks equilibriated near the transition between epidote-blueschist facies and albite-epidoteamphibolite facies (Figure 3-4). All these blocks contain garnet which is partially replaced by chlorite. Thus, the early stage of metamorphism must have been in the garnetbearing part of epidote-blueschist facies. In these blocks garnet is partially replaced by chlorite; garnet formed first at a temperature above reaction 7 and chlorite later, below reaction 7 (Figure $3-4$ ). The presence of clinozoisite instead of lawsonite in some blocks provides an upperpressure/lower-temperature-limit for the second stage of metamorphism - the boundary between epidote - and lawsonite- 
blueschist facies (Evans, 1990). The pressure is lower for these blocks, since they contain albite and no omphacite, than for the epidote blueschist blocks of the Jagua Clara melange.

Epidote blueschists: 84-12 does not show any clear evidence of metamorphism besides that of the epidote blueschist facies.

More accurate estimation of $\mathrm{P}-\mathrm{T}$ conditions would be possible if microprobe analyses of pyroxene and garnet were available for RSJC complex rocks. The Ellis and Green geothermometer (1979) has been applied to garnets and clinopyroxenes from a wide range of geological environments and could be used with these rocks to better constrain the temperature of metamorphism. 


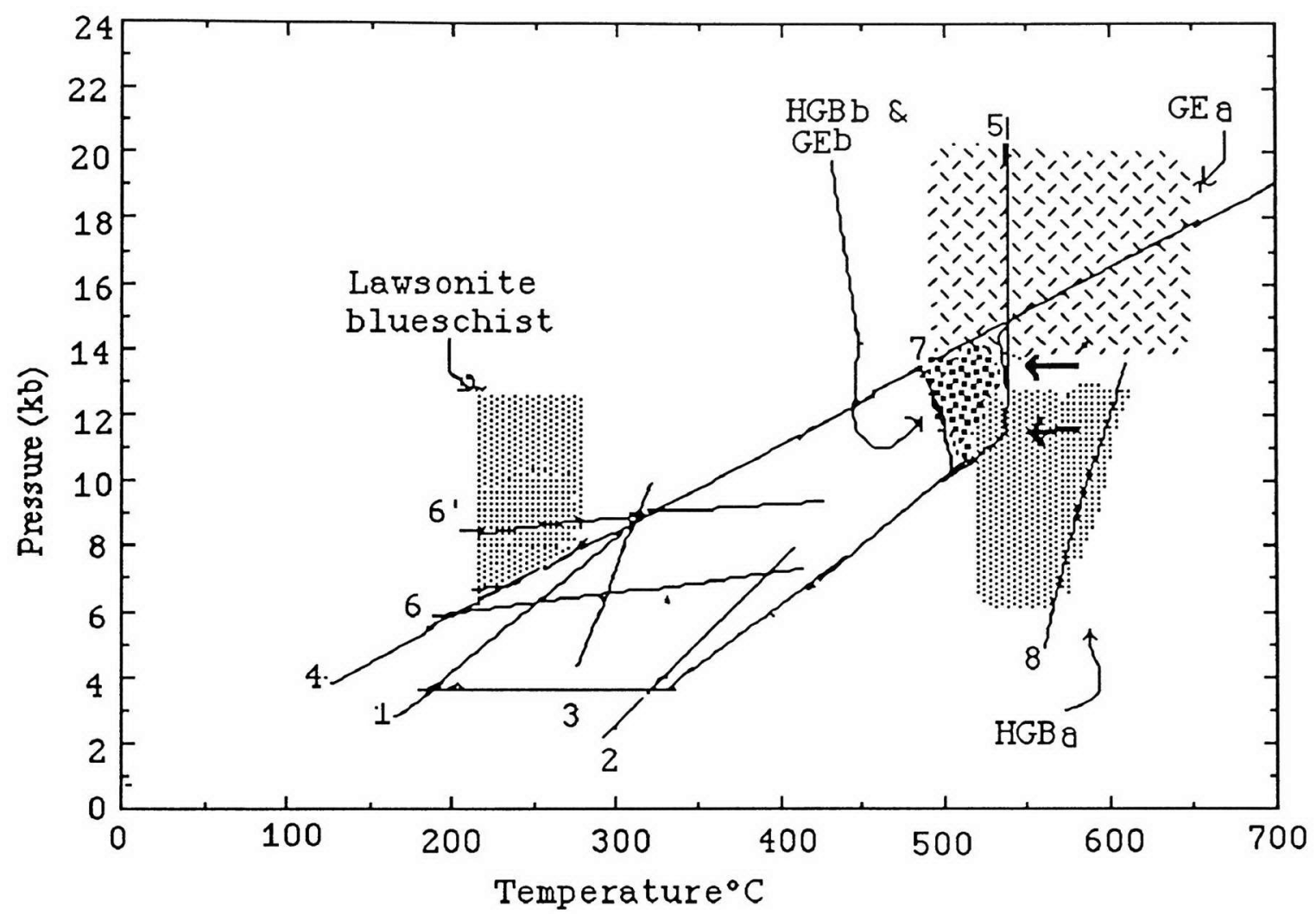

Figure 3-3. P-T conditoins of some blocks of Jagua Clara melange. Reactions 1-6, 6' same as for figure 3-2.

(7) Garnet = Chlorite (Avigad et al., 1992), (8) Minimum temperature hornblende (Winkler, 1979). HGBa = albiteepidote-amphibolite(?), $\mathrm{HGBb}$ and $\mathrm{GEa}=$ epidote blueschist. $\mathrm{GEa}=$ Hornblende eclogite. Areas labeled HGBa and b show conditions for hornblende-garnet blueschist blocks during early and late stages of metamorpism, respectively. $\mathrm{GEa}$ and $\mathrm{b}$ indicate early and late stages of metamorphism for glaucophanic eclogite blocks. 


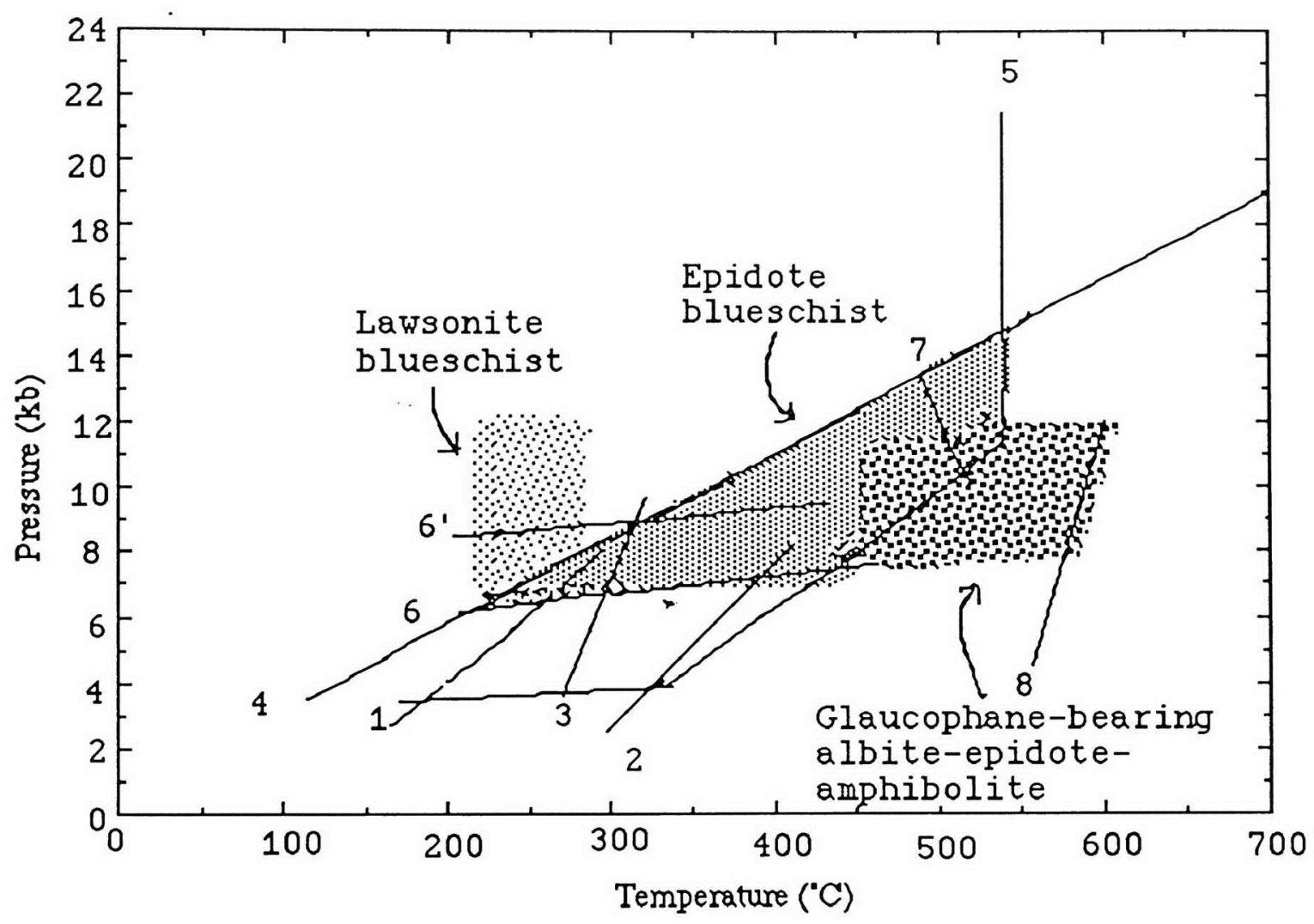

Figure 3-4. P-T conditions of Arroyo Sabana melange. Reactions as in Figures $3-2$ and $3-3$. 


\section{SUMMARY OF CONDITIONS OF METAMORPHISM}

The coherent Hicotea and Puerca Gorda Schists were both metamorphosed at $\mathrm{T}=250-400^{\circ} \mathrm{C}$ and $\mathrm{P}=7-10 \mathrm{~kb}$. The melange blocks cover a wider range of metamorphic conditions than the coherent units. Table 3-2 summarizes the pressure and temperature conditions of the different blocks of melange. Eclogite blocks are not seen in the Arroyo Sabana melange, although garnet and hornblende are present. The higher temperature minerals - hornblende, garnet and omphacite - are absent in the coherent schists. All three of these minerals are present in some blocks of the Jagua Clara melange. Blocks of Jagua Clara melange were metamorphosed at higher pressures and temperatures than the blocks in the Arroyo Sabana melange and any of the rocks from the coherent schists. Hornblende-bearing blueschists in both melanges and eclogites in the Jagua Clara melange, were metamorphosed at higher temperatures than the coherent-schist rocks. There was a 75 to $150^{\circ} \mathrm{C}$ temperature drop in overprinted blocks of Jagua Clara melange. The presence of hydrous minerals (epidote, clinozoisite, glaucophane, chlorite, phengite, actinolite, hornblende, etc.) in the RSJC units indicate the rocks were metamorphosed in water-rich fluid. The maximum $\mathrm{X}_{\mathrm{CO} 2}$ in the fluid was about .01 (Figure 10, Evans (1990). 


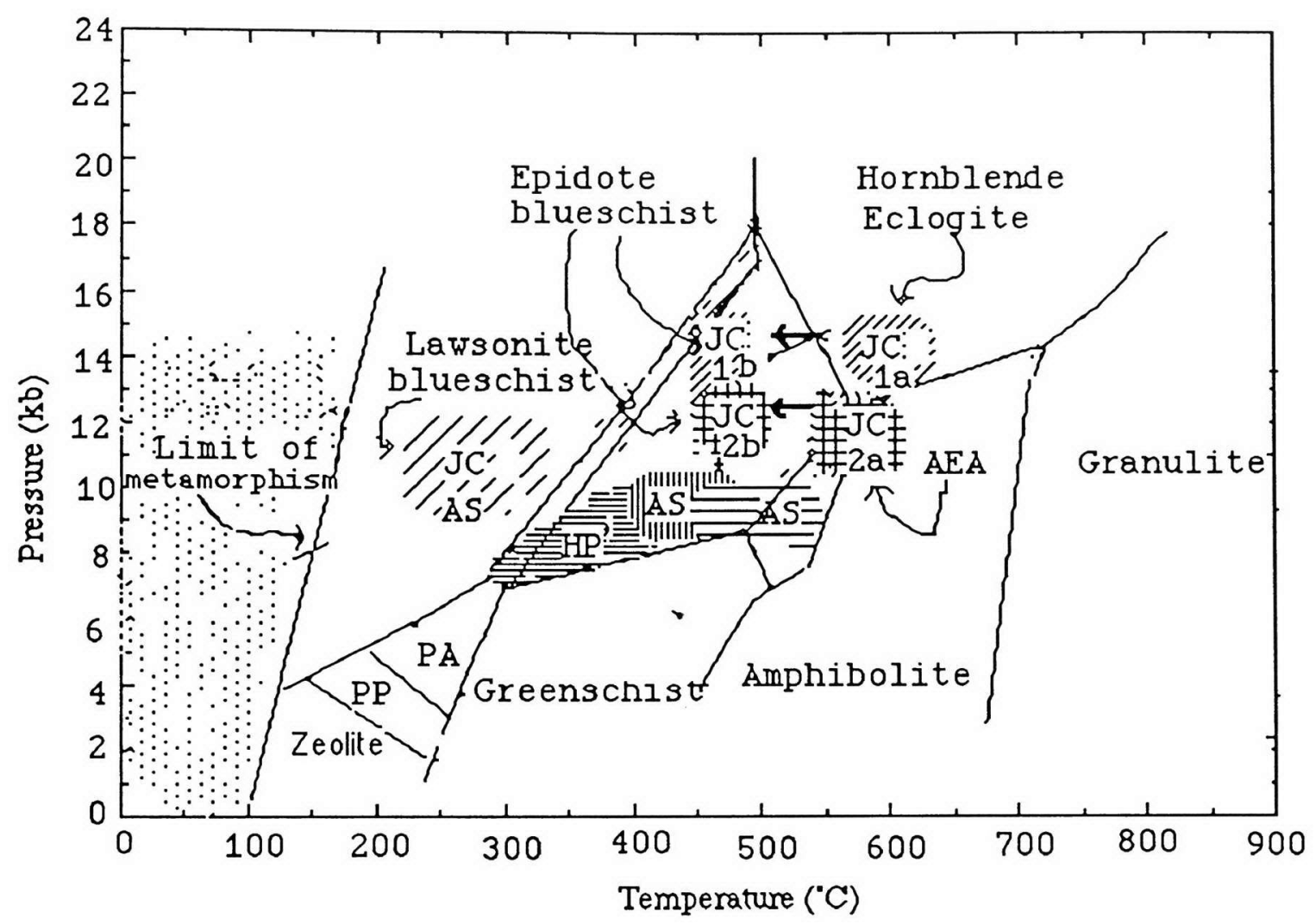

Figure 3-5. P-T conditions of northern part of Rio San Juan Complex. PA=pumpellyite-actinolite, PP=prehinitepumpellyite, JC=Jagua Clara melange, $\mathrm{HP}=\mathrm{Hicotea}$ and.

Puerca Gorda schists, $\mathrm{AEA}=$ albite epidote amphibolite, $A S=A r r o y o$ Sabana melange, $a=$ early, $b=$ late assemblages. Horizontal rulling = glaucophane-bearing albite-epidote-amphibolite, vertical rulling = epidote blueschist. 
TABLE: 3-2. P-T OF DIFFERENT BLOCKS

\begin{tabular}{|c|c|c|c|c|c|c|}
\hline \multirow[t]{2}{*}{ BLOCK TYPE } & \multirow{2}{*}{ UNIT } & \multicolumn{2}{|c|}{ METAMORPHICFACIES } & \multicolumn{2}{|c|}{ TEMPERATURE $\left({ }^{\circ} \mathrm{C}\right)$} & \multirow{2}{*}{$\begin{array}{c}\text { PRESSURE } \\
\mathrm{kbr}\end{array}$} \\
\hline & & early or only & late & early/only & late & \\
\hline Lawsonite blueschist & $\mathrm{JC}, \mathrm{AS}$ & lawsonite blueschist & & $250-375$ & & 7 to $\sim 25$ (?) \\
\hline epidote blueschist & AS & epidote blueschist & & $325-515$ & & 7 to $(?)$ \\
\hline $\begin{array}{l}\text { glaucophanic } \\
\text { eclogite }\end{array}$ & $J$ & $\begin{array}{l}\text { AEA } \\
\text { to type } C \text { eclogite }\end{array}$ & $\begin{array}{c}\text { epidote } \\
\text { blueschist }\end{array}$ & $500-700$ & $\sim 425-\sim 550$ & 8 to $18(?)$ \\
\hline $\begin{array}{l}\text { Glaucophane-bearing } \\
\text { albite-epidote- } \\
\text { amphibolite }\end{array}$ & AS & AEA & & $\sim 500-\sim 550$ & & 10 to $14(?)$ \\
\hline $\begin{array}{l}\text { hornblende-garnet } \\
\text { blueschist }\end{array}$ & $\mathrm{JC}$ & $\begin{array}{l}\text { amphibolite facies } \\
\text { or AEA }\end{array}$ & $\begin{array}{l}\text { epidote } \\
\text { blueschist }\end{array}$ & $\begin{array}{l}500-550 \\
500-550\end{array}$ & $425-500$ & $\begin{array}{l}7 \text { to } 14(?) \\
7 \text { to } 12(?)\end{array}$ \\
\hline
\end{tabular}

$\mathrm{JC}=\mathrm{Jagua}$ Clara,$\quad \mathrm{AS}=$ Arroya Sabana,$\quad A E A=$ albite epidote amphibolite only=only one stage , early = first stage of two stages of metamorphism, late $=$ second stage $\mathrm{cf}$ metamorphism 
C

\section{GEOCHEMISTRY}




\section{Introduction}

Thirteen samples were chosen for bulk rock chemical analysis. Samples were analyzed using an ICPES (Inductively Coupled Plasma Emission Spectrometer). Two of these samples are taken from the Hicotea Schist, four are from the Puerca Gorda Schist and seven samples are taken from the two melange units.

\section{Analytical Techniques}

Details of analytical techniques are described in Appendix I. Samples are fused at $1050^{\circ} \mathrm{C}$ by using lithium metaborate as a flux and then dissolved in $50 \mathrm{ml}$ of $1.5 \mathrm{~N}$ acid solution. This solution was used for trace element analyses. Then a $2.5 \mathrm{ml}$ aliquot of the same solution was diluted with $47.5 \mathrm{ml} 1.5 \mathrm{~N}$ nitric acid. This diluted solution was used for major element analyses. To evaluate the precision of techniques three readings were taken for each sample analysis.

\section{Major and Trace Elements}

The major and trace element analyses of thirteen samples from the Rio San Juan Complex are presented in Appendix II (Table II-1, and Table II-2).

$\mathrm{SiO}_{2}$ contents in the Rio San Juan Complex vary from 46\% to $58 \%$. The rocks have a wide range of $\mathrm{Al}_{2} \mathrm{O}_{3}$ contents from 
$13 \frac{0}{0}-18 \%$, except one sample $(83-144)$ which has a very low $\mathrm{Al}_{2} \mathrm{O}_{3}$ of only 3.40wt. $\frac{\circ}{0}$. Total iron $\left(\mathrm{Fe}_{2} \mathrm{O}_{3}\right)$ concentrations in the RSJC range from $6 \%$ to $17 \%$, but the average concentration is 7\%-10\%. MgO contents in the RSJC range from $4 \%-23$ wt. $\frac{8}{8}$ with a majority of samples between $4 \%-10 \mathrm{wt} . \% \mathrm{~K}_{2} \mathrm{O}$ concentrations in the RSJC range from $\sim 0.45 \%$ to $2.13 \mathrm{wt} . \%$. $\mathrm{Na}_{2} \mathrm{O}$ concentrations in the RSJC range from $1.72 \%$ to $4.89 \mathrm{wt}$. $\frac{0}{0}$ with a majority of samples containing 3\% to $4 \mathrm{wt} . \% \mathrm{Na}_{2} \mathrm{O}$. The CaO contents in the RSJC vary from 2 to $12.48 \mathrm{wt} . \%$, with most of the rocks having a concentration of 6-11wt. $\frac{\%}{\circ} \mathrm{TiO}_{2}$ contents are $.04 \%$ to $3.23 \mathrm{wt} . \%$ with a majority between $0.60 \%$ to 2 wt. $\frac{\circ}{\circ}$.

The $\mathrm{SiO}_{2}$ contents and bulk compositions of Rio San Juan complex indicate that these rocks are basalt to basaltic andesite (Table II-1, and Figures 4-1 and 4-2) except the sample 83-144, because this sample has more than $20 \% \mathrm{MgO}$ and less than 4\% $\mathrm{Al}_{2} \mathrm{O}_{3}$. Sample 83-144 (Arroyo Sabana melange) is a part of a rind where serpentine has been metasomatically altered to talc. It is excluded from this discussion because it does not have a basaltic composition. $\mathrm{Na}_{2} \mathrm{O}$ and $\mathrm{K}_{2} \mathrm{O}$ values, which are normally used as parameters in the classification of volcanic rocks show an erratic distribution in the RSJC rocks. The distribution of these two elements suggests that they might have been mobilized after volcanic extrusion. On basalt classification plots such as Figure 4-1 (Miyashiro, 1974) and Figure 4-2 (Irvine and Baragar, 1971), the RSJC 
rocks plot partially in the tholeiite and partially in the calc-alkaline fields.

The petrographic studies and bulk compositions of Rio San Juan rocks show they are volcanic in nature. Therefore, I apply different tectonomagmatic discriminant diagrams that can be used to determine the tectonic affinity of basaltic rocks. Data from recent island arc basalt complexes in the Lesser Antilles, (Brown, 1977), from the central Caribbean (DSDP Leg 15, Sen et al., 1988) and E-type MORB (within plate, seamount basalts) from Duarte Complex, Central Hispaniola (Lewis and Jimenez, 1991) are compared with the data from the Rio san Juan complex to test the validity of the different tectonomagmatic discriminant diagrams.

HFSE (high field strength elements; $\mathrm{Zr}, \mathrm{Ti}, \mathrm{Y}, \mathrm{Nb}$ ) are considered to be immobile during low to moderate grades of metamorphism or metasomatic alteration (Pearce and Norry, 1979). The HFSE in basaltic rocks are used primarily to discriminate volcanic rock types and magma series. Trace elements least affected during low grade metamorphism are: Co, Cr, Nb, Y, Ti, Zr (Cann, 1970). However, later studies show that $Y$ and REE can be mobilized during intermediate temperature alteration by seawater (Kuschel and Smith, 1992). Elements $\mathrm{Sr}$ and $\mathrm{K}$ are effective in distinguishing magma types, but they are highly affected by alteration, being depleted during spilitisation and enriched during weathering 
(Pearce, 1975). In the RSJC, abundance ranges for immobile trace elements are: Co 22 to $55 \mathrm{ppm}, \operatorname{Cr} 24$ to $824 \mathrm{ppm}$, Nb n.d. (not dectected) to $10 \mathrm{ppm}, \mathrm{Ti} 3192$ to $19380 \mathrm{ppm}$ and $\mathrm{zr}$ 37 to $233 \mathrm{ppm}$. $Y$ and $\mathrm{Sr}$, also used on the plots, have abundance ranges of 14 to $85 \mathrm{ppm}$ and 36 to $585 \mathrm{ppm}$, respectively.

Figures 4-3, 4-4 and 4-5 show the samples on different tectonomagmatic discriminant diagrams. On Figure 4-3 $\left(\mathrm{TiO}_{2}-\right.$ $\mathrm{MnO}-\mathrm{P}_{2} \mathrm{O}_{5}$; Mullen, 1983) island arc tholeite samples from the Lesser Antilles plot with island arc tholeite (IAT), but eight of fifteen specimens from Leg 15 also plot with island arc tholeiites (IAT), three with mid oceanic ridge basalts (MORB), and the other four with ocean island tholeiites (OIT). Three samples from the Duarte Complex fall in three different fields: IAT, MORB and OIT. On the same diagram, samples from the Rio San Juan Complex plot in different fields; samples 83-198, 83-142b, 83-138, 84-20 and 84-100 plot with calc-alkalic basalts ( $C A B)$, samples 84-12, 84-16 and 84-78b plot with MORB, samples 83-142d and 84-77 plot with ocean island alkalic basalts (OIA); samples 84-82 and 84-13 plot in the field of IAT.

On the $\mathrm{Ti}, \mathrm{Zr}$ and $\mathrm{Y}$ ternary tectonomagamatic diagram (Figure 4-4, Pearce \& Cann, 1973) all five samples from the Lesser Antilles plot in $B$ and $C$ fields, indicating affinities with calc-alkaline basalt and ocean floor basalts (OFB) and 
also island arc basalts. Two of the Leg 15 samples plot with within plate basalts (WPB), one in the field of IAB and one in the field of OFB. Four of five Duarte samples plot with WPB, and one falls on the border of the A and B fields. Six $(84-78 b, 84-12,84-16,83-142 d, 83-198$ and 84-77) of 12 samples from the RSJC plot within field B which is the common field of both island arc basalts and ocean floor basalts. Three specimens (84-100, 84-20, and 83-142b) fall in field C and samples 83-138, and 83-142b plot outside of the fields.

On a Ti, Zr, Sr ternary diagram (Figure 4-5, Pearce and Cann, 1973), all of the samples from the Lesser Antilles (IAB) plot with calc-alkaline basalt. Three of the four Leg 15 samples (ocean floor basalts) plot with ocean floor basalts, but one other sample plots just above the ocean floor basalt field. Two of six samples from Duarte plot in the OFB field, three in the IAB field and one outside of the fields. Samples from the RSJC show different affinities: samples $84-20,84-77,83-142 b, 84-82$ and $84-13$ plot with CAB, 84-16 plots in the field of $O F B$ and 84-78b, 83-142d, 84-12, 84-100, 83-138, and 83-198 plot outside of the fields.

On a Ti vs. Zr discrimination diagram (Eigure 4-6; Pearce, 1973), all of the samples from the Lesser Antilles plot with CAB. Three of four samples of Leg 15 plot with OFB, and one sample plots on the boundary of the IAT field. Five of six samples from the Duarte complex plot in the OFB 
field and one plots on boundary line of the IAT and OFB fields. In the RSJC, samples 84-16, 84-78b, 83-142d and 8412 plot with OFB, 83-138, 84-13, 84-77, 83-142b, 84-100, 8420 and 84-82 plot with $\mathrm{CAB}$; and sample 83-198 plots with IAT.

Ti versus Cr may be reliable indicator of magma type for altered volcanic rocks, especially for distinguishing arc basalts from ocean floor basalts (Pearce, 1975). On the TiCr diagram (Figure 4-7), all of the samples from the Lesser Antilles plot with field of the IAB. All of the samples from the Duarte Complex plot in the OFB field. Samples from the Dummisseau Formation (ocean floor basalts) are OFB. Similar to the other diagrams samples 83-142d,84-16, 84-12, and 84$78 \mathrm{~b}$ plot in the OFB fields, whereas all other samples from the RSJC plot with IAB.

Although most samples plot within definite fields on the discriminant diagrams, some do not. For these, the effects of metasomatic alteration, and the redistribution of elements carried in fluids may be a factor.

Metasomatic alteration of Rio San Juan rocks is clearly revealed by geochemical and petrographic studies. Modification of the geochemistry of low grade Rio San Juan rocks is reflected in the high values of loss of ignition (LOI) of up to 9.23응 (Table 11-1). Fluids are generally believed to play an important role in low grade metamorphism and alteration. Evidence for the role of fluid pressure is 
the presence of hydrous minerals such as chlorite, micas (white mica; phengite, fuchsite), amphiboles (Na-amphiboles, actinolite-tremolite, hornblende), epidote, clinozoisite, lawsonite and talc; which all are present in RSJC rocks. At low temperature, the supercritical fluid becomes water rich. Water is important in metamorphic reactions because of its influence in transmitting pressure, permitting formation of hydrous minerals and increasing the rate of reaction, by breaking down mineral bonds and transporting constituents. Circulating water, with its high solvent power serves as a means of transportation of elements.

In RSJC rocks, rutile, sphene and apatite are present as accessory minerals. These accessory minerals concentrate key trace elements such as $\mathrm{Ti}, \mathrm{La}, \mathrm{P}, \mathrm{Nb}$ and $\mathrm{Y}$ (Rankama and Sahama, 1968). Sphene and rutile contain titanium as a major constituent. Sphene is an important carrier of lanthanum and yttrium. $\mathrm{Nb}$ is found in rutile. Apatite includes $\mathrm{P}$ as a major element and $L a$ and $Y$ as trace elements. As fluids circulate through the rocks, these metamorphic minerals may act as sinks for elements Ti, $\mathrm{Zr}, \mathrm{Nb}, \mathrm{P}$, and REE, causing local concentration that may influence the composition of the bulk rock (Sorenson, 1990). Therefore, metasomatic alteration, particularly in rocks with REE, Ti, Nb, $\mathrm{P}$ and $\mathrm{Zr}-$ bearing accessory minerals, may limit the usefulness of tectonomagmatic discriminant diagrams. 


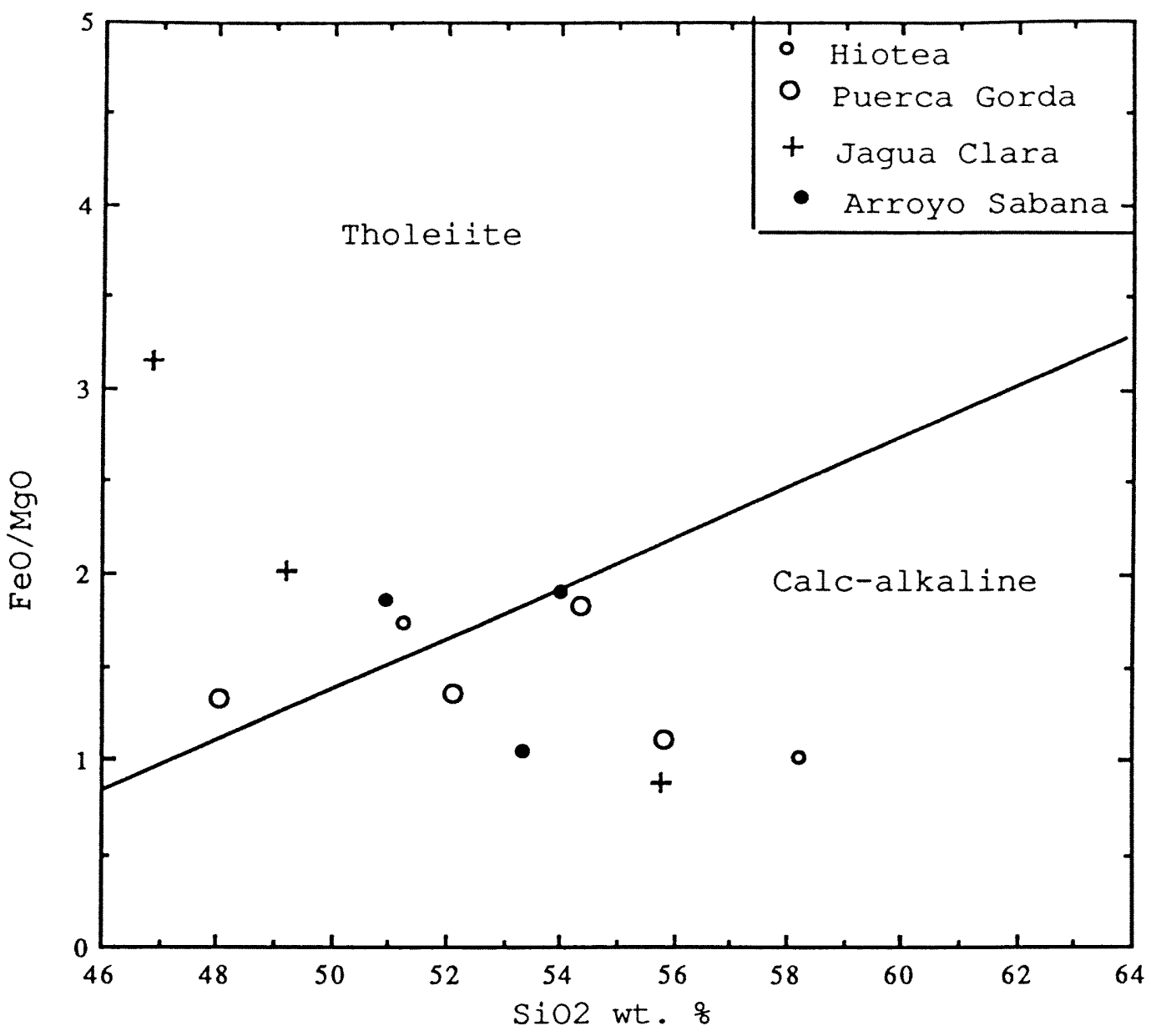

Figure 4-1. Samples from the RSJC fall in the both tholeiite and calc-alkaline fields in Miyashiro's diagram (1974). 


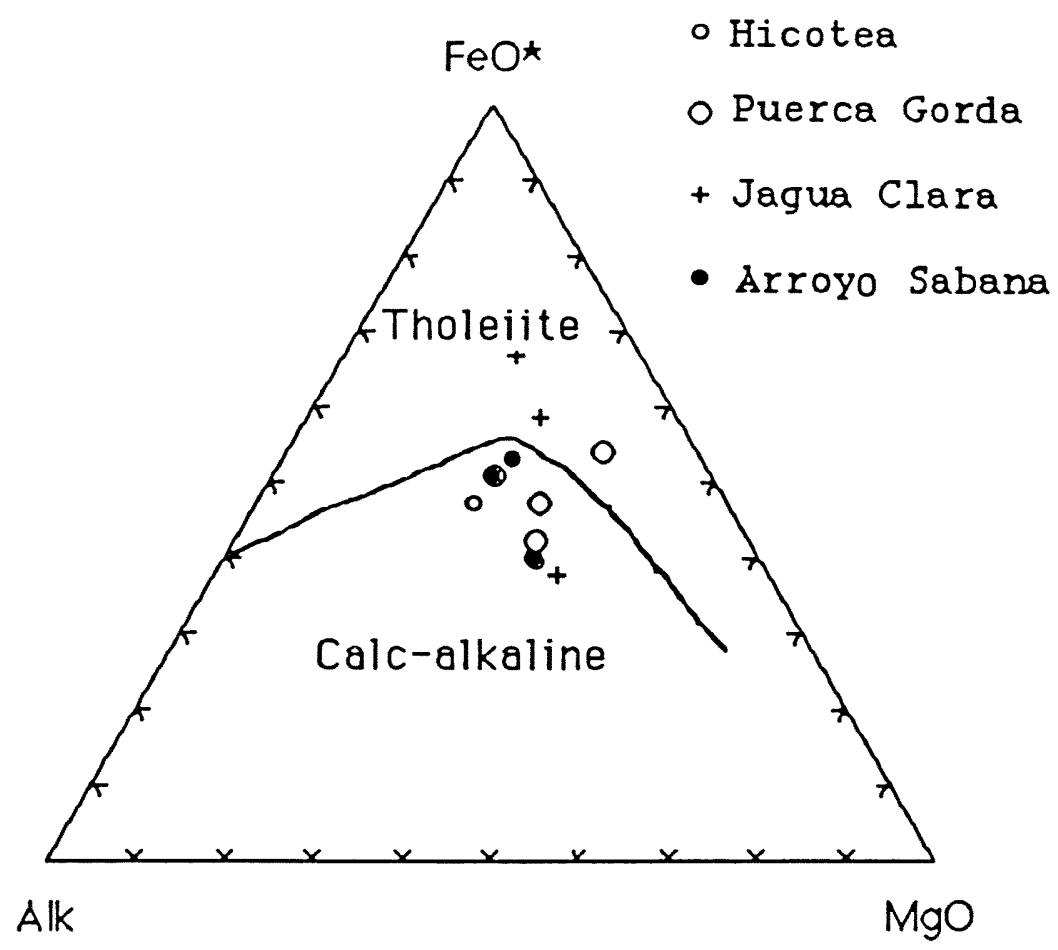

Figure 4-2. Data from the Rio San Juan Complex plotted on an AFM diagram (Irvine and Baragar, 1971). 


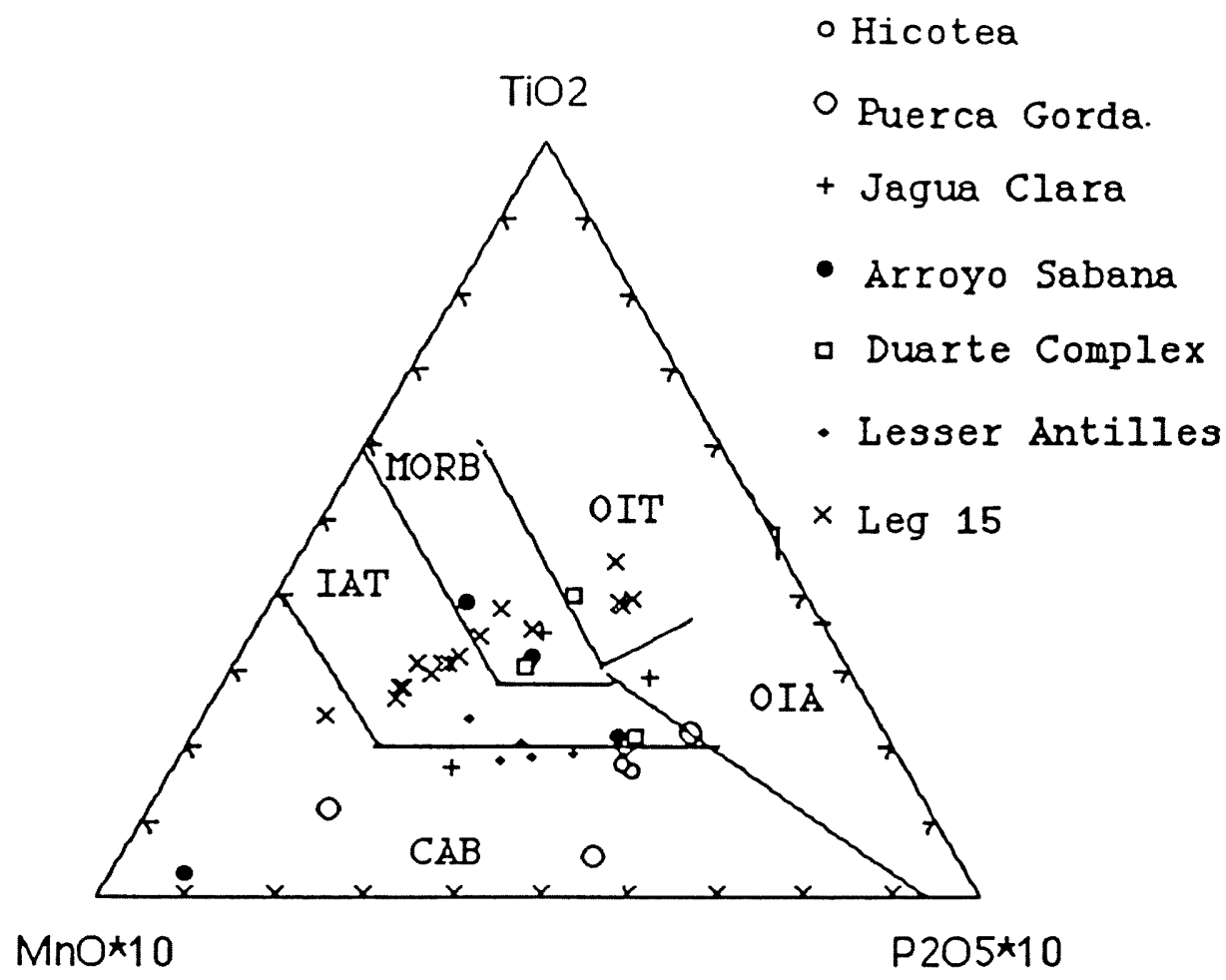

Figure 4-3. $\mathrm{TiO}_{2}$, MnO and $\mathrm{P}_{2} \mathrm{O}_{5}$ tectonomagmatic diagram (after Mullen, 1983). CAB=calc-alkaline basalts. MORB=mid oceanic ridge basalts, IAT= island arc tholeiites. OIT ocean island tholeiites. OIA=island alkalic basalts. 


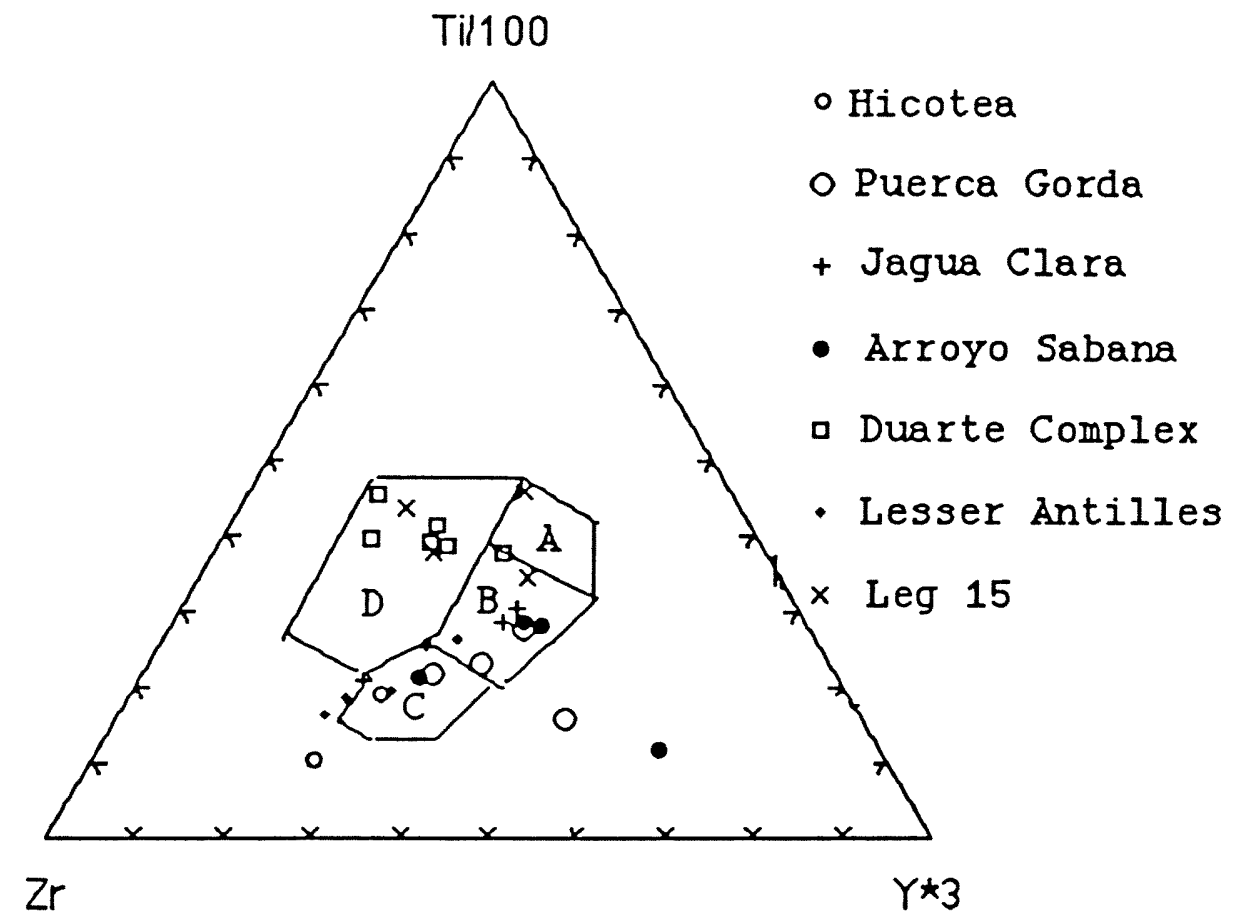

Figure 4-4. Ti, $\mathrm{Zr}$ and $\mathrm{Y}$ tectonomagmatic diagram distinguishing different tectonic environments.

$A \cdot B=I A B ; B=O F B ; B, C=C A B ; D=W P B$. 


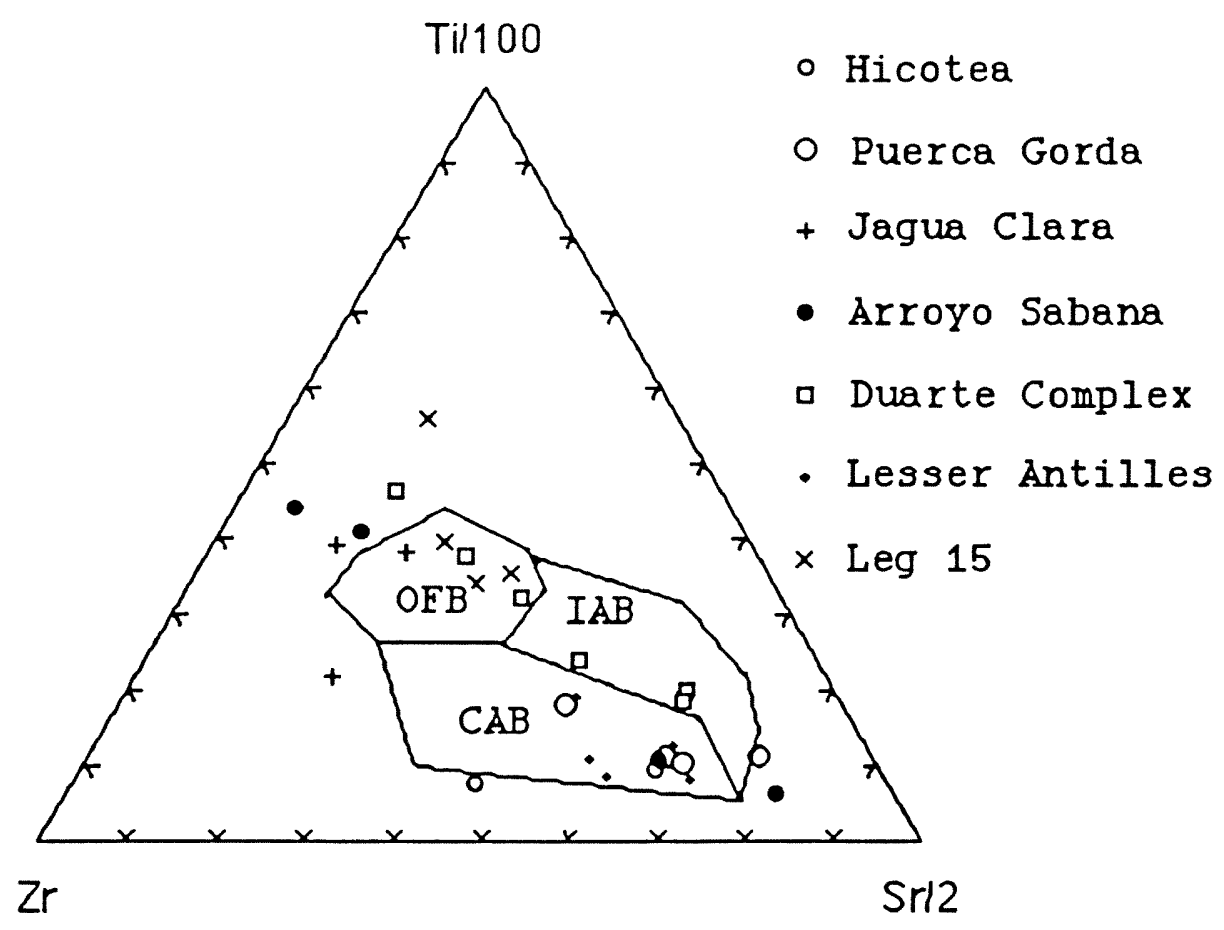

Figure 4-5. Ti, $\mathrm{Zr}$ and $\mathrm{Sr}$ triangle diagram for the RSJC (after Pearce and Cann, 1973). 


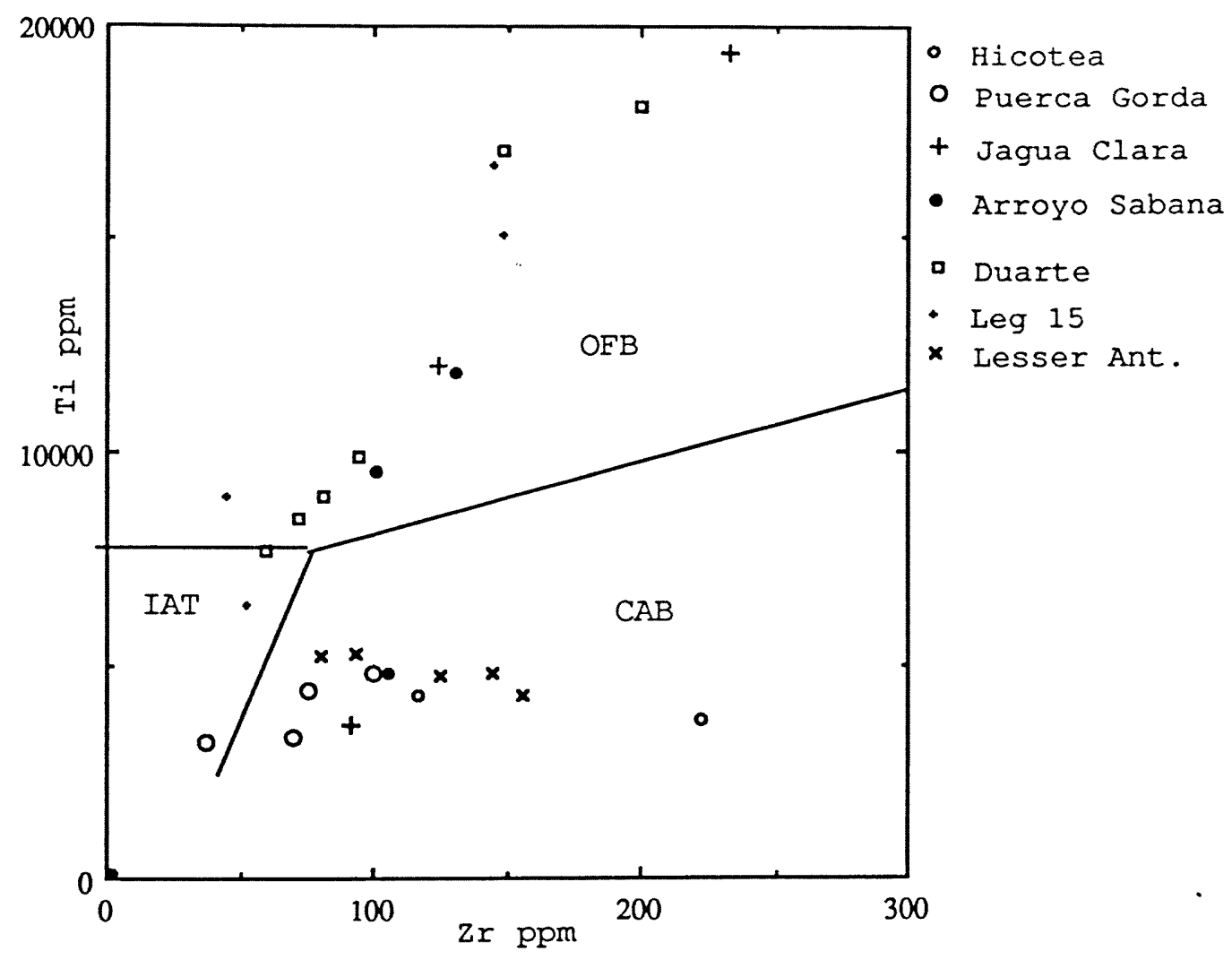

Figure 4-6. Plot of Ti vs. Zr. Field boundaries are taken from Garcia (1979) and are similar to those of Pearce and Cann (1973). 


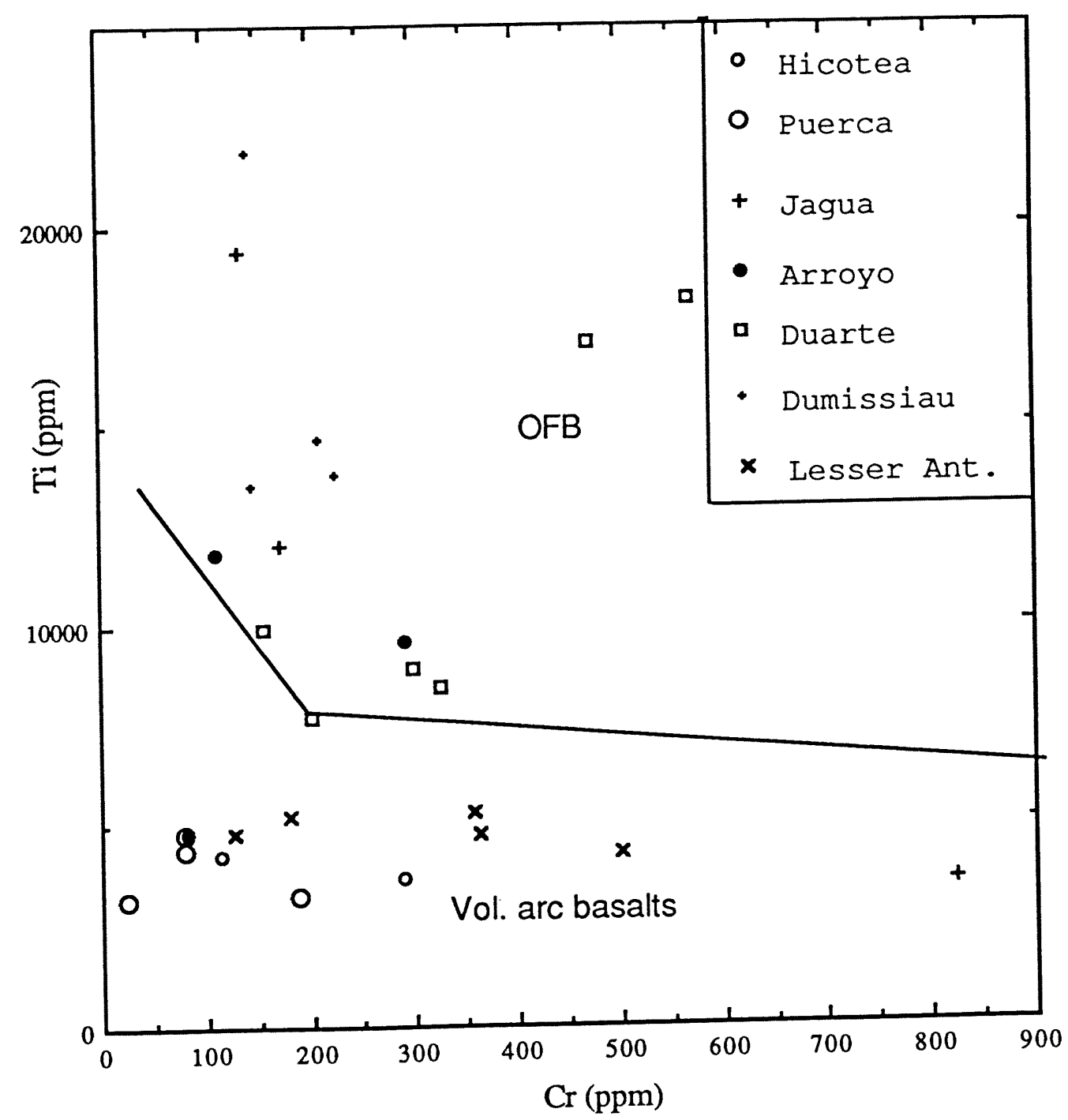

Figure 4-7. Ti-Cr plot for ocean floor basalts. The boundary of the fields is taken from Garcia (1979) and is somewhat different than those presented by Pearce (1975). 
In Table 4-1, the results of all the tectonomagmatic provenance diagrams are summarized. In the table, samples that plotted outside of the usual fields, possibly due to metasomatic alteration, are indicated by NIF (not in field). Samples 84-20, 84-100, 84-77 (except Figure 4-5, OIA), 83142b (except Figure 4-6, not in field (NIF), 84-13 (except Figure 4-5, IAT), 84-82 (except Figure 4-5, IAT) and 83-138 (except Figure 4-6, and 4-7, NIF) have predominantly CAB tectonic affinities. Sample 83-198 plotted with both IAT and $\mathrm{CAB}$ in different diagrams. Samples 84-16, 83-142d (except Figure 4-5, OIA), 84-12 and 84-78b consistently show a tectonic affinity with MORB/OFB. From this table all the samples may broadly classified in two groups; samples 84-12, 84-16, 83-142d, 84-78b have MORB/OFB affinity and all other rocks have IAB affinity. All four MORB/OFB samples are from the melange units. Samples 84-16 and 83-142d are Jagua Clara melange blocks and samples $84-12$ and 84-78b are Arroyo Sabana blocks.

Based on Table 4-1, all (8) the samples from coherent schists have tectonic affinities with island arc basalts. Four of six samples of melanges are MORB/OFB and the other two are island arc basalts.

On Figure 4-8, the difference between an IAT-type and MORB-type RSJC rocks is shown on a normalized trace element abundance diagram. MORB-type rocks have high normalized Ti, 
$Y$ contents, and small relative depletions of $\mathrm{Nb}$. IAT-type rocks have depletion of HFSE, and a pronounced depletion of $\mathrm{Nb}$. Both types, on this diagram are generally enriched in LIL ( $\mathrm{Ba}$ and $\mathrm{K}$ ) relative to $\mathrm{HFSE}$, but this may be the result of metasomatic alteration. 
TABLE: 4-1. SAMPLES PLOTTED IN DIFEERENT TECTONOMAGMATIC DIAGRAMS

\begin{tabular}{|c|c|c|c|c|c|c|c|c|c|c|c|c|}
\hline \multirow[t]{2}{*}{ Diagrams } & \multicolumn{2}{|c|}{ Hicotea } & \multicolumn{4}{|c|}{ Puerca Gorda } & \multicolumn{3}{|c|}{ Jagua Clara } & \multicolumn{3}{|c|}{ Arroya Sabana } \\
\hline & $83-138$ & $84-20$ & $83-198$ & $84-77$ & $83-142 b$ & $84-13$ & $84-16$ & $84-100$ & $83-142 d$ & $84-12$ & $84-78 b$ & $84-82$ \\
\hline Eig. $4-3$ & $\mathrm{CAB}$ & $\mathrm{CA}$ & 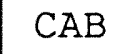 & OI & 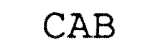 & $\mathrm{T}$ & MORB & $\mathrm{CAB}$ & OIA & MORB & MORB & $T$ \\
\hline Fig. 4-4 & NIF & C & II & If & & B & MORB & $\mathrm{CAB}$ & $\mathrm{MO}$ & MORB & MORB & CAE \\
\hline Fig. 4-5 & NIF & $\mathrm{CAB}$ & NIF & $\mathrm{CAB}$ & $\mathrm{CAB}$ & $\mathrm{CAB}$ & OFB & NIE & NIF & NIF & NIE & CAE \\
\hline Eig. 4-6 & $\mathrm{CAB}$ & $\mathrm{CAB}$ & IAT & $\mathrm{CAB}$ & $\mathrm{CAB}$ & $\mathrm{CAB}$ & OFB & $\mathrm{CAB}$ & OFB & OFB & OFB & CAE \\
\hline ig. 4-7 & $I A B$ & IAB & IAB & IAB & IAB & IAB & OFB & $\mathrm{IAB}$ & OFB & OFB & OFB & {$[\mathrm{A}$} \\
\hline
\end{tabular}

NIE $=$ NOT OE EIELD 
Rock/Chondrites (except Rb, K, P)

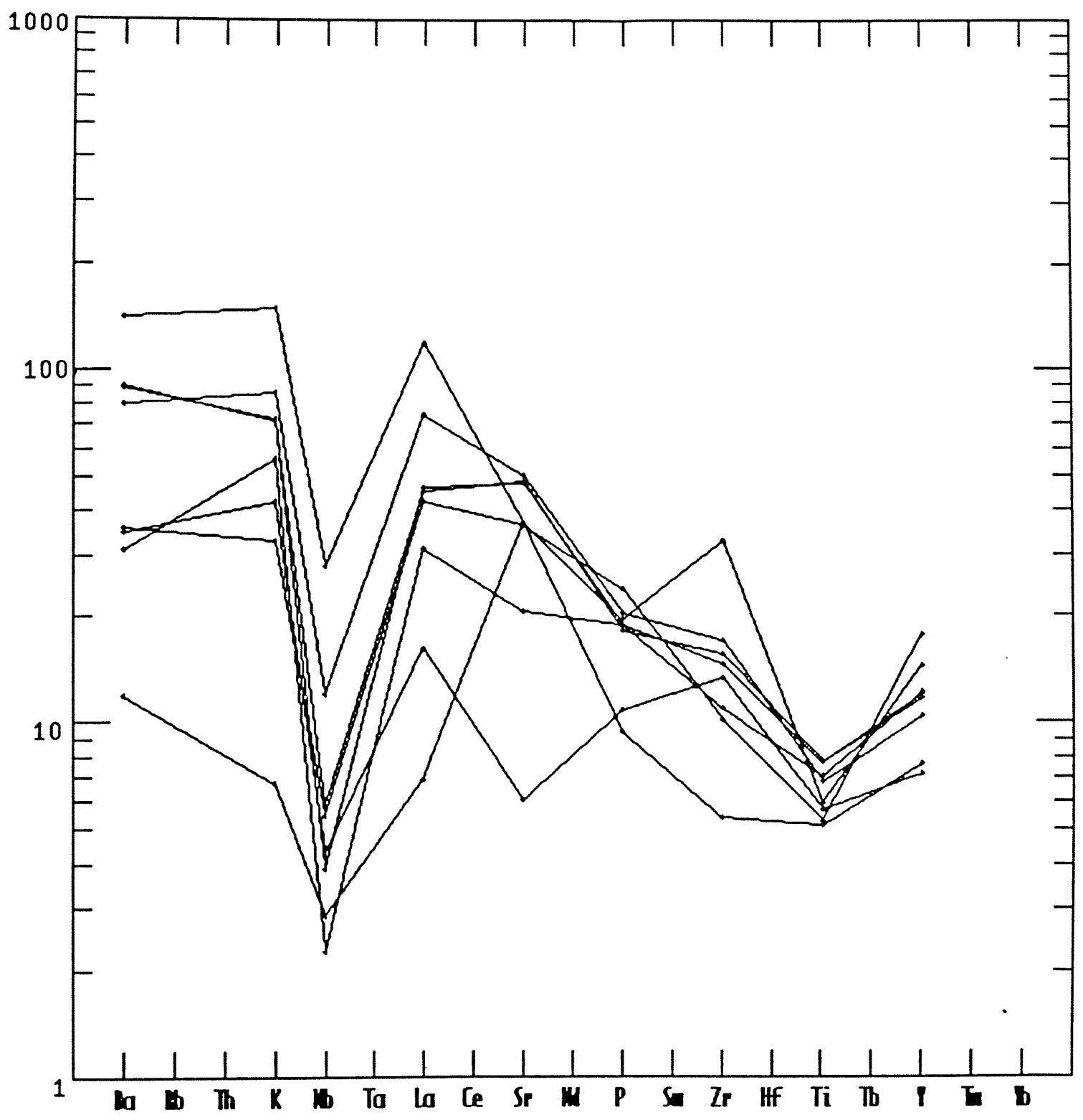

Figure 4-8(a). Spidergram of trace element variation diagram for the RSJC rocks (IAB rocks). Normalizing values are for chondrites, except Rb, K, P (Thompson et al., 1984). 
Rock/Chondrites (except Rb, K, P)

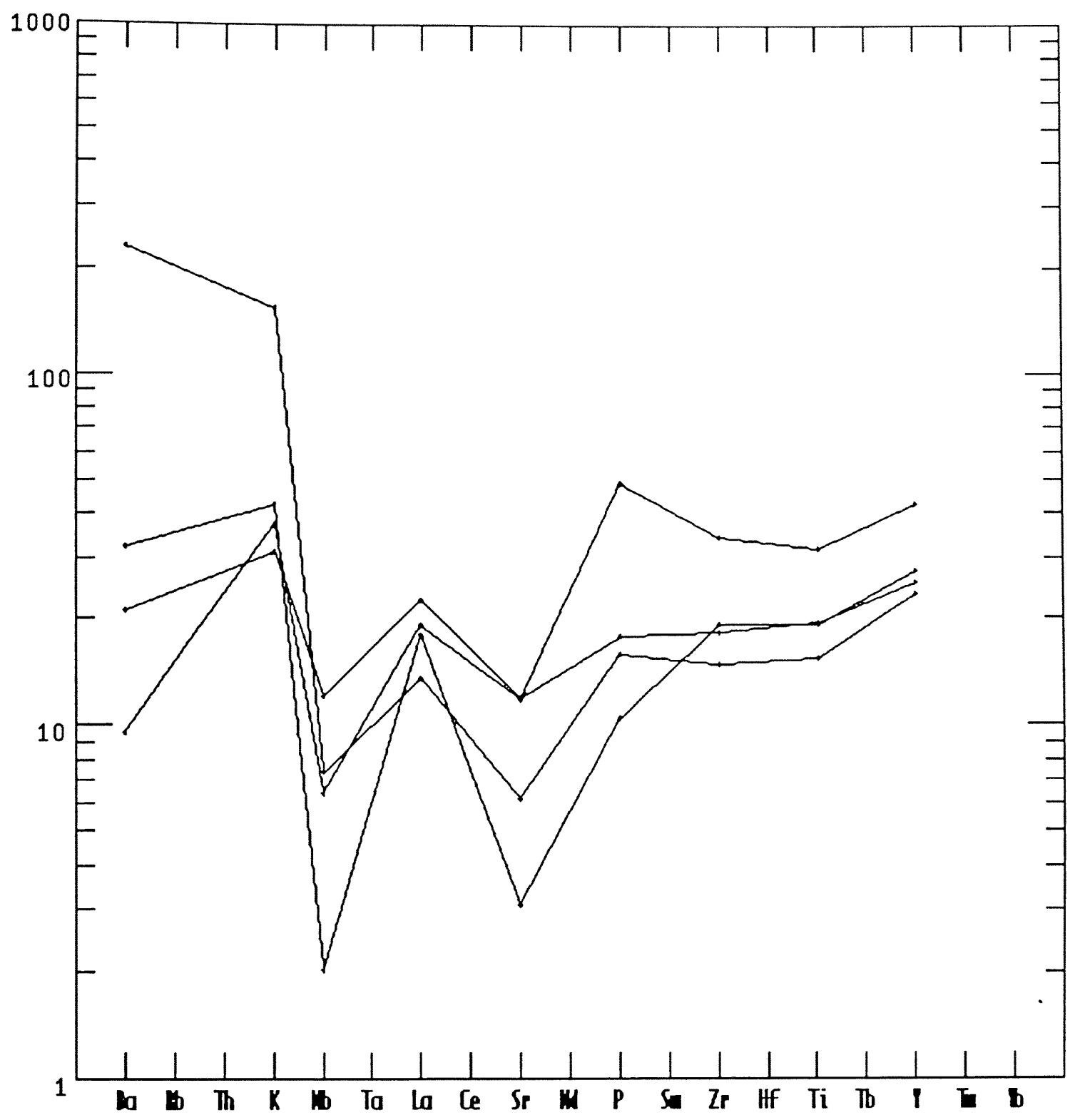

Figure 4-8(b). Spidergram of trace element variation diagram for the RSJC rocks (MORB rocks). Normalizing values are for chondrites, except Rb, K, P (Thompson et al., 1984). 


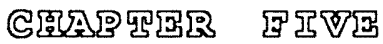

DISCUSSION AND CONCIUSIONS 


\section{CONCLUSIONS AND MODEL}

\section{SUMMARY OF THE CHARACTERISTICS OF THE RIO SAN JUAN COMP LEX}

Any successful tectonic model for the evalution of the Rio San Juan Complex must be able to explain the various features of the Complex found by previous workers and those revealed in this study.

\section{Field Occurrence}

Draper and Nagle (1991) established that the northern Rio San Juan Complex is composed of two high-pressure coherent schist units and two serpentinite melange units which contain high-pressure blocks. In addition, there are several major serpentinite bodies, but these only contain rare diabase blocks.

\section{Protoliths}

The petrographic textures and geochemical compositions of specimens indicate that the protoliths of the RSJC units were generally igneous in nature. From the different tectonomagmatic diagrams (Figure 4-3, 4-4, 4-5, 4-6, and 4-7) it was seen that all the rocks of the Hicotea and the Puerca 
Gorda Schists have an island arc provenance and their textures indicate they are volcanic.

In contrast, blocks of the melanges have a dual provenance. Four specimens (two from the Jagua Clara melange and two from Arroyo Sabana melange) apparently have ocean floor basalt affinities. Two of the six samples of melange have an apparent island arc provenance. Metasomatic alteration of Rio San Juan rocks is clearly seen in the geochemical studies. Possible modification of the geochemistry of the low grade Rio San Juan rocks is reflected in the high values of ignition loss, highly variable alkali element abundances, and the scatter on tectonomagmatic discriminant plots.

\section{Metamorphism}

The Hicotea and Puerca Gorda schists were metamorphosed at a temperature of $250-400^{\circ} \mathrm{C}$ at $7-10 \mathrm{~kb}$. Assuming a pressure gradient of about $0.28 \mathrm{~kb} / \mathrm{km}$ for the region in which the Rio San Juan Complex formed, the depths of metamorphism of the Hicotea and Puerca Gorda schists are about 19 to $28 \mathrm{~km}$.

On the other hand, the blocks within the melange units display a wide range of metamorphic condition. The blocks of the Arroyo Sabana melange were metamorphosed at temperatures of between $275^{\circ} \mathrm{C}$ and $550^{\circ} \mathrm{C}$ and $7-10 \mathrm{~kb}$ (about $19-28 \mathrm{~km}$ ). The 
epidote-blueschist blocks which display only a single phase of metamorphism were metamorphosed at $300-375^{\circ} \mathrm{C}$ and $7-12 \mathrm{~kb}$.

In the Jagua Clara melange some blocks showed two metamorphic events In those blocks, the earlier stage (eclogite) metamorphism took place at $500-550^{\circ} \mathrm{C}$ and $7-16 \mathrm{~kb}$ (19-45), but the later epidote blueschist overprint was at $300-375^{\circ} \mathrm{C}$ and 7 to $10 \mathrm{~kb}$.

\section{Age Relationships}

No fossils have been found to determine age of the protolith of the RSJC rocks. Systematic geochronological studies to determine the age of metamorphism are also lacking. In fact, only one ${ }^{40} \mathrm{Ar} /{ }^{39} \mathrm{Ar}$ age exists and that is of a hornblende-phengite-bearing block from the Jagua Clara Melange. The date indicates a cooling age of 85.1 Ma for the hornblende and a $61.8 \mathrm{Ma}$ age for the phengite (Renne, in Draper and Nagle, 1991). If this is representative of other blocks, it indicates that blueschist metamorphism must have occurred during Late cretaceous to early Tertiary time. It is still unclear whether these cooling dates occurred before, or after, incorporation into the melange.

Draper and Nagle (1991) report that early to middle Eocene limestones rests disconformably on the RSJC, and this would indicate that the RSJC was eroded and exposed by or before $50 \mathrm{Ma}$. 


\section{A TECTONIC MODEL FOR THE DEVELOPMENT OF THE RSJC}

Although there can be more than one tectonic model for development of the RSJ rocks, any successful model must be able to explain the results of observations summarized above. The following tectonic model is proposed.

According to Draper and Lewis (1991) arc activity began in Hispaniola in pre-Albian time, associated with a northeastward-dipping subduction zone (Figure 5-1). They suggested that the early arc edifice covered a seamount structure which is represented by the Duarte Complex of central Hispaniola. As the volcanism continued, the Duarte terrane was further covered by the Tireo formation, which formed in Turonian to early Campanian time (Bowin, 1966, 1975). Draper and Lewis (1991), Mattson (1979), Bourdon (1985), and Lebron and Perfit (1993) all proposed that a reversal of subduction polarity took place during the early development of the arc. According to Draper and Lewis (1991) the reversal took place during the Campanian, but according to Lebron and Perfit (1993) reversal took place in the Early Cretaceous. Draper and Lewis (1991) suggested that this reversal was the result of a collision of the south-facing arc and that this collision also caused an inter-arc basin to 
close, emplacing the ophiolite of central Hispaniola. Subduction resumed on the northern side of the arc. This southward-dipping subduction zone and resulting arc volcanism continued until middle Eocene time.

The geologic evidence invoked for the polarity reversal model is that the present-day outcrop of high pressure/low temperature metamorphic rocks are found along the southern flanks of Greater Antilles in Cuba and Puerto Rico (Mattson, 1979). It is argued that these were formed in the earlier subduction zone and that the younger high pressure/low temperature rocks along the northern flank of arc resulted from the later subduction.

The model presented here is consistent with the polarity reversal outlined above. It is proposed that when the subduction began on the northern side of Hispaniola, lower Cretaceous arc deposits that had formed during the south facing phase were underthrust into the new subduction zone and metamorphosed. In the initial stage of subduction, the hanging wall was sufficiently hot to metamorphose the downgoing ocean crust (and some overlying arc rocks) to amphibolite and the lower temperature part of eclogite facies (Figure 5-2). These slices of the downgoing slab were then accreted to the hanging wall.

As subduction continued, the cold ocean floor entering the subduction zone drew down the isotherms even further to 
create an inverted geothermal gradient (Figure 5-3). This came in contact with the early accreted eclogites and amphibolites producing the lower-temperature epidoteblueschist overprint (probably at about 75 Ma or latest Campanian). As the temperatures in the subduction zone became low enough (i.e. less than $500^{\circ} \mathrm{C}$ - Raleigh and Patterson, 1965) serpentinization of the peridotite in the hanging wall could have occurred and the earlier metamorphosed rocks became entrained as blocks in the serpentinite to form the Jagua Clara melange. As an alternative, serpentine could have come from fracture zones in descending oceanic crust. The Arroyo Sabana melange may have formed in a similar manner in an adjacent part of the subduction complex, but at shallower levels (15-28 km) than the Jagua Clara melange.

It is proposed the Hicotea and Puerca Gorda schists were metamorphosed when a slice of early arc entered the subduction complex. This probably occurred in a different location in the subduction zone than the formation of the melanges and possibly later (Figure 5-4).

Juxtaposition of coherent terranes and melange bodies may have occurred either by underplating and/or by strikeslip faulting in the subduction complex resulting from oblique convergence. Possible continued underplating resulted in uplift and exposure of the RSJC complex before 
mid Eocene. Alternatively, the final uplift and exposure of the RSJC may have been the result of introducing the buoyant southern margin of the Bahahmas into the subduction zone during the early Eocene (Pindell and Draper, 1991).

\section{FUTURE STUDIES}

The Rio San Juan Complex is a major occurrence of high pressure, low temperature metamorphic rocks in the northern Caribbean orogenic system. This work is clearly only a beginning of possible studies on the complex. Future studies that would improve the findings presented in this thesis include:

- Search for fossils in the coherent units. Many original textures are preserved and perhaps fossils might be preserved in the metatuffaceous units and associated marbles.

- Better sampling of blocks in the two melange units for both petrology and geochronology

- Geochronological studies on these samples to determine if the one age determination available is typical.

- More geochemical studies to see if the results obtained in this study are representative. Studies of the accessory minerals would be interesting as they probably play an important role regarding the loss or abundance of trace elements concentrations in the rocks. 
- More quantitative estimates of the $\mathrm{P}$ and $\mathrm{T}$ of metamorphism. Use of the electron microprobe might be used to study the chemistry of individual minerals. Probe analysis of the minerals could also allow use of accurate geothermometers and geobarometers that may eventually be used to construct a $\mathrm{P}-\mathrm{T}-$ $t$ curve for the rocks. 

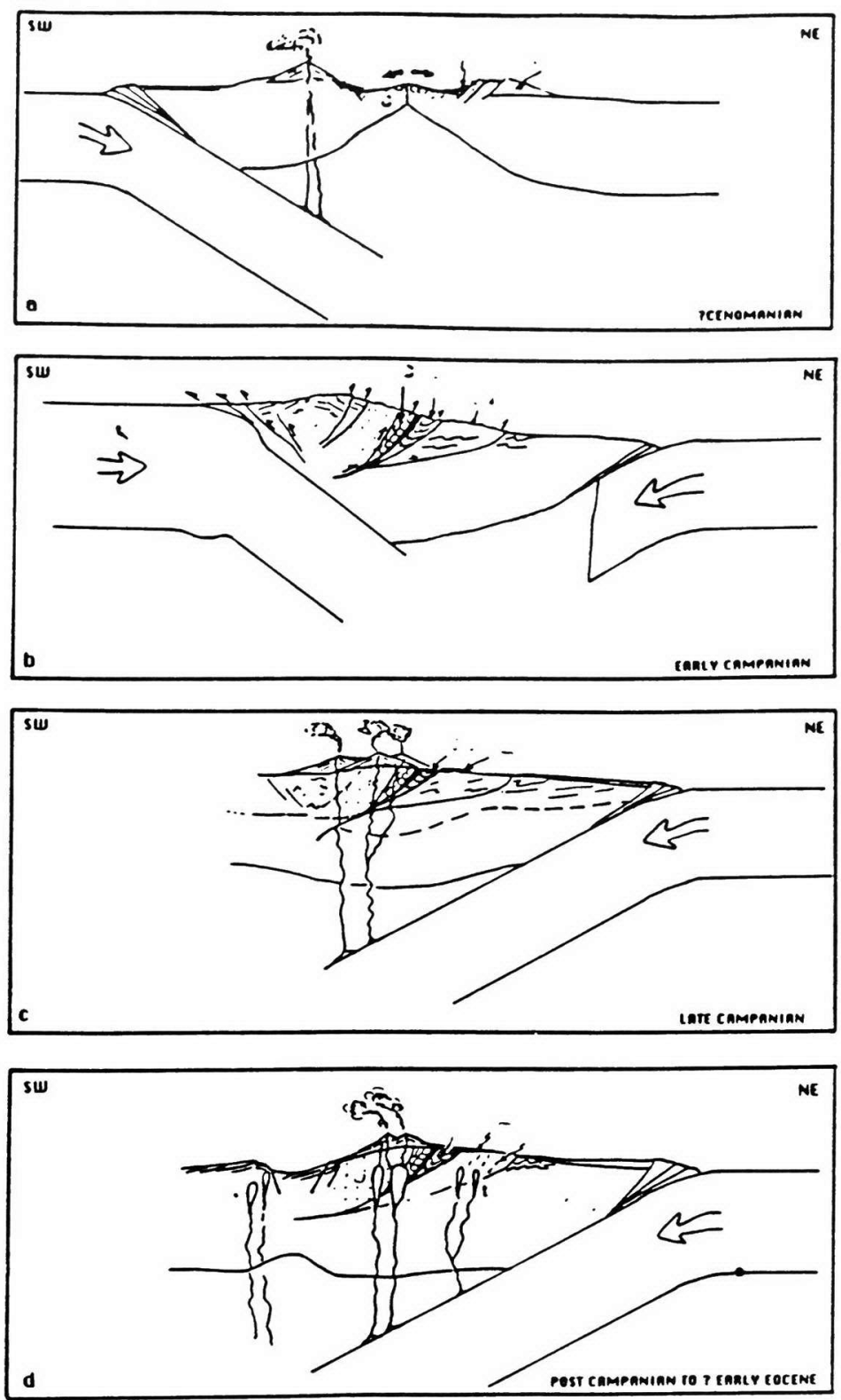

Figure 5-1. Cartoon showing hypothesied tectonic development of Central Hispaniola (Lewis and Draper, 1991). 


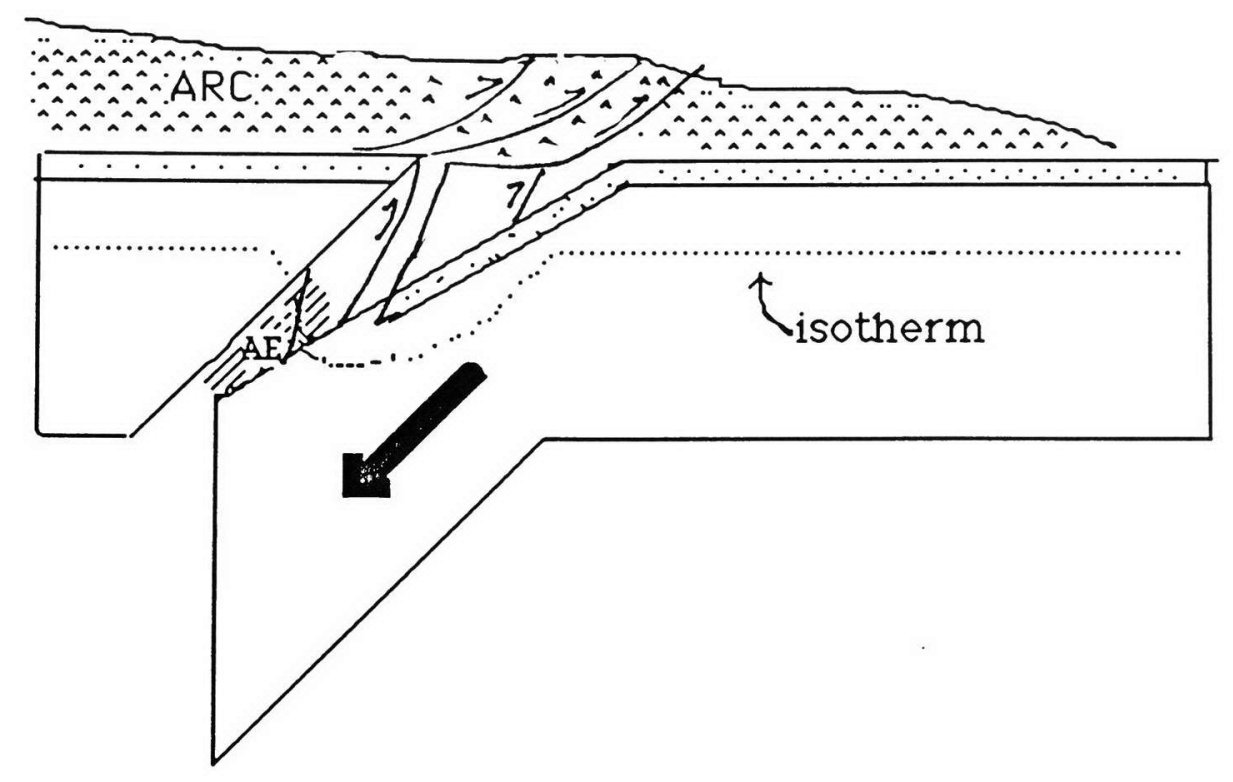

Figure 5-2. In initial stage of subduction, heat from hanging wall metamorphoses downgoing ocean crust and some over-lying arc rocks to amphibolite and eclogite facies. These slices accreted to hanging wall. $\mathrm{AE}=$ amphibolite and eclogite. 


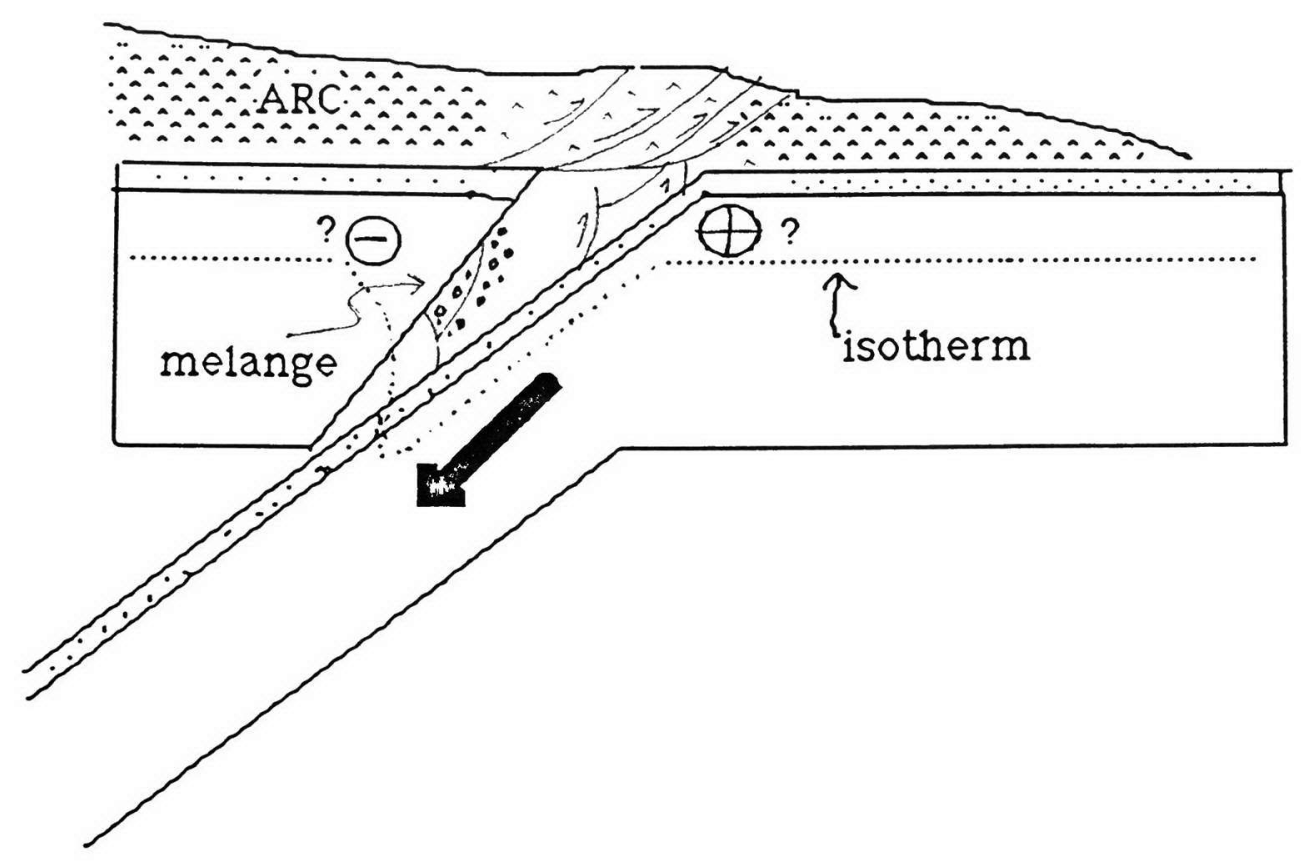

Figure 5-3. As subduction continues, cold ocean floor enters subduction zone and draws down the isotherms. Heat flow from eclogites and amphibolite produces refrigerating isotherms are low enough to allow serpentization to occur and formed Jagua Clara melange. Arroyo Sabana melange fromed in a different part of subduction complex. slighty less deep. 


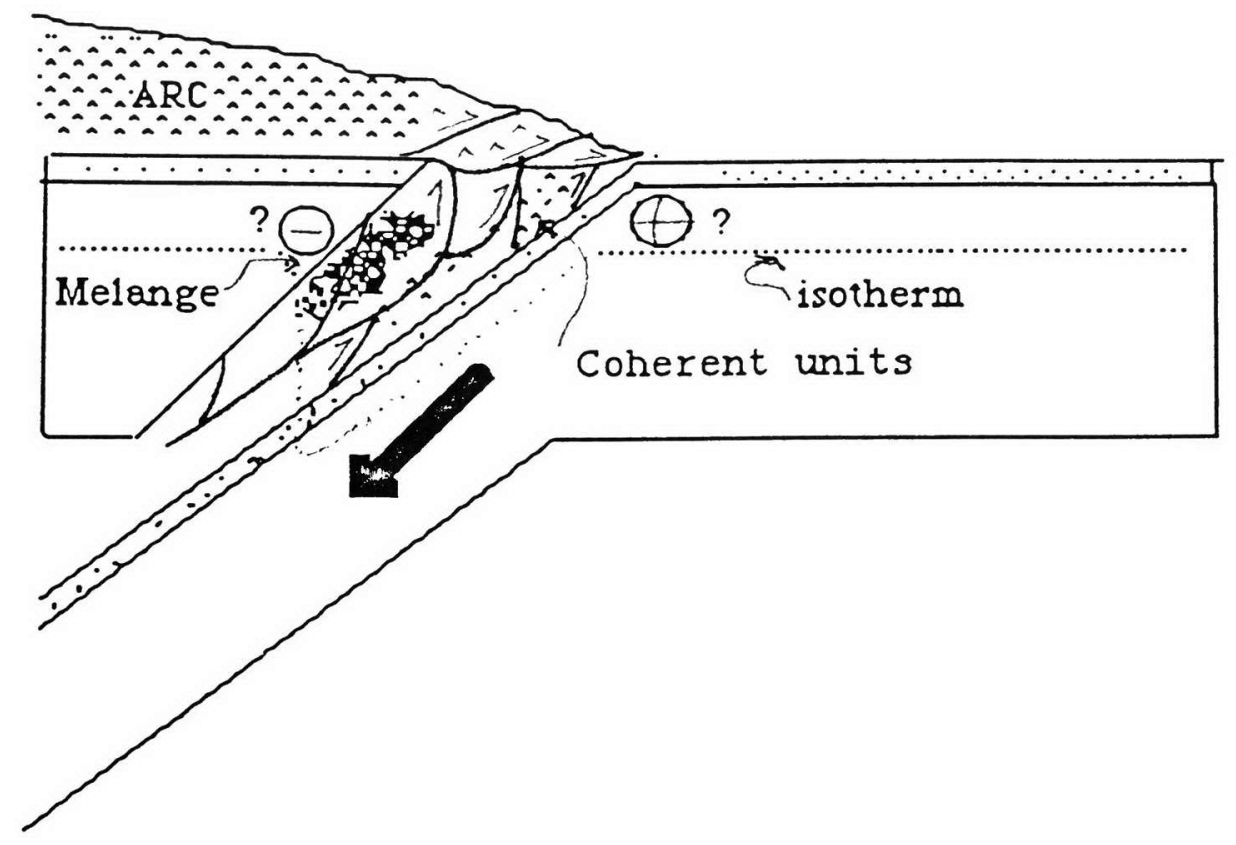

Figure 5-4. The Hicotea and Puerca Gorda Metamorphosics when a slice of an arc is accreted in the subduction complex, probably in a different location in the subduction zone than the melanges.

Continued underplating uplifts and exposes the RSJ complex before mid Eocene. 


\section{REFERENCES}

Avigad, D., Mathews, A., Evans, B.W, and Garfunkel, Z., 1992, Cooling during the exhumation of a blueschist terrane: Sifnos (Cyclades), Greece, European Journal of Mineralogy, 4, 619-634.

Beall, R, 1944, The geology of the Eastern Cibao Basin Dominican Republic, Dominican Seabord Oil Company, Report, New York Office No. 35, Santo Domingo (unpublished report).

Bloxam, T.W., and Lewis, A.D., 1972, Ti, Zr, and $\mathrm{Cr}$ in some British pollow lavas and their petrogenetic affinities, Nature Physical Science, 237, 134.

Boettcher, AL, and Wyllie, P.J., 1969, Phase relationships in the system $\mathrm{Na} \mathrm{AlSiO}_{4}-\mathrm{SiO}_{2}-\mathrm{H}_{2} \mathrm{O}$ to 35 kilobars pressure, American Journal of Science, 15, 67-92.

Bourdon, L., 1985, La Cordillere Orientale Dominicaine (Hisopaniola, Grandes Antilles): un ard insulaire Cretace ploystructure: Unpublished Ph.D. thesis, Universite Pierre et Marie Curie, Paris, p.203.

Brothers, R.N., \& Yokoyama, 1982; Composition of the HighPressure Schist Belts of New Caledonea and Sanabagwa, Japan, Contributions to Mineralogy and Petrology, 79, $219-229$. 
Brown, E.H., 1974, Comparison of the mineralogy and phase relations of blueschists from the North Cascadesm, Washington, and greenschists from Otago, New Zealand, Geological Society of America Bulletin, 85, 333-344.

Brown, E.H., 1977, Phase equilibria among pumpellyite, lawsonite, epidote and associated minerals in low grade metamorphic rocks, Contributions to Mineralogy and Petrology, 64, 123-136.

Brown, E.H., and O'Neil, J.R., 1982, Oxygen isotope geothermometry and stability of lawsonite and pumpellyite in the shuksan suite, Contributions to Mineralogy and Petrology, 80, 240-244.

Brown, E.H., and Ghent, E.D., 1983, Mineralogy and phase relations in the blueschist facies of the Black Butte and Ball Rock areas, northern California coast ranges, American Mineralogist, 68, 365-372.

Brown, G.M., et al., 1977, Geochemistry of the Lesser Antilles volcanic island arc, Geochimica et Cosmochimica Acta, 41, 785-801.

Cann, J.R., 1970, Rb, Sr, Y, Zr, and $\mathrm{Nb}$ in some ocean-floor basaltic rocks, Earth \& Planetary Science Letters, 19, $7-11$. 
Carman, J.H., and Gilbert, M.C, 1983, Experimental studies on glaucophane stability, American Journal of Science, $283-A, 414-437$.

Cloos, M., 1985, Thermal evolution of convergent platemargins: thermal modelling and re-evalution of isotropic Ar-ages for blueschists in the Franciscan complex of California, Tectonics, 4, 421-433.

Coleman, R.G., and Lanphere, M.A., 1971, Distribution and age of high-grade blueschists, associated eclogites, and amphibolites from Oregon and California, Geological Society of America Bulletin, 82, 2397-2412.

De Roever, E.W.F., Beunk, 1976, Blue amphibole-albitechlorite assemblages from Fuscalde (S. Italy) and role of glaucophane in metamorphism, Contributions to Mineralogy and Petrology, 58, 221-234.

De Zoeten, R., and Mann, P., Structural geology and Cenozoic tectonic history of the central cordillera Septentrional, Dominican Republic, Geological Society of America Special Paper, 262, 265-280.

Draper, G., and Nagle, F., 1986, Geological setting and characteristics of blueschist and eclogite bearing melanges in Northern Hispaniola, Transactions of the 11th Caribbean Geological Conference, Barbados, 33:1$33: 9$. 
Draper, G., 1986, Blueschists and associated rocks in eastern Jamaica and their significance for Cretaceous platemargin development in the northern Caribbean, Geological Society of America Bulletin, 97, 48-60.

Draper, G., and Lewis, J.F., 1991, Metamorphic belts in central Hispaniola, Geological Society of America Special Paper, 262, 29-45.

Draper, G., Nagle, F., and Renne, P.R., 1991, Geology, structure and tectonic development of the Rio San Juan Complex, northern Dominican Republic, Geological Society of America Special Paper, 262, 77-95.

Elberle, W., Hirdes, W.G., Muff, R., and Pelalz, M., 1982, The geology of the Cordillera Septentrional (Dominican Republic), Transactions of the 9th Caribbean Geological Conference, Santo Domingo, Dominican Republic, 619-632.

Ellis, D.J., and Green, D.H., 1979, An experimental study of the effect of $\mathrm{Ca}$ upon garnet-clinopyroxene Fe-Mg exchange equilibria, Contributions to Mineralogy and Petrology, 71, 13-22.

Essene, E.J., 1989, The current status of thermobarometry in metamorphic rocks, Evolution of Metamorphic Belts, Geological Society Special Publication No.43, 1-44. 
Evans, B. W., 1990, Phase relations of epidote-blueschists, Lithos, 25, 3-23.

Fyfe, W.S., and Turner. F.J., 1966, Reappraisal of the concept of metamorphic facies, Contributions to Mineralogy and Petrology, 12, 354-364.

Garcia, M.O., 1979, Petrology of the Rogue and Galice Formations, Klamath Mountains, Oregon: Identification of a Jurassic island arc sequence, Journal of Geology, $86,29-41$.

Heinrich, W., and Athaus, E., 1980, Die overe Stabilitatsgrenze von Lawsonite plus Albit bzw. jadeit. Fortschritte der Mineralogie, 58,49-50.

Holland, T.J.B., 1988, Priliminary phase relations involving glaucophane and applications to high pressure petrology: new heat capacity and thermodynamic data, Contributions to Mineralogy and Petrology, 99, 134-142.

Holland, T.J.B., 1980, The reaction albite = jadeite + quartz determined experimentally in the range $600-1200^{\circ} \mathrm{C}$, American Mineralogist, 65, 129-134.

Holland, T.J.B., 1979, Experimental determination of the reaction paragonite=jadeite + kyanite $+\mathrm{H}_{2} \mathrm{O}$, and normally consistent thermodynamic data for part of the system $\mathrm{Na}_{2} \mathrm{O}-\mathrm{Al}_{2} \mathrm{O}_{3}-\mathrm{SiO}_{2}-\mathrm{H}_{2} \mathrm{O}$, with applications to eclogites 
and blueschists, Contributions to Mineralogy and Petrology, 68, 293-301.

Irvine, T.N., and Baragar, N.R.A., 1971, A guide to chemical classification of the common volcanic rocks, Canadian Journal of Earth Science, 8, 523-548.

Joyace, J., 1991, Blueschist metamorphism and deformation on the Samana Peninsula - a record of subduction and collision in the Greater Antilles, Geological Society of America Special Paper, 262, 47-76.

Koons, P.0., 1986, Relative geobarometry from high-pressure rocks of quartzofeldspathic composition from the sesia Zone, Western Alps, Italy, Contributions to Mineralogy and Petrology, 66, 75-80.

Kuschel, E., and Smith, E.M., 1992, Rare earth mobility in young arc-type volcanic rocks from northern New Zealand, Geochimica et Cosmochimica Acta, 56, 3951-3955.

Lebron, M.C., and Perfit, M.R., 1993, Stratigraphic and petrological data support subduction polarity reversal of the Cretaceous Caribbean island arc, Journal of Geology, 101, 389-396.

Lewis, J.F. \& Draper, G., 1990, Geology and tectonic evolution of the northern Caribbean margin, in Dengo, G., J.E. ed., The Caribbean region: Boulder, Colorado, 
Geological Society of America, The Geology of North America, v. H, 77-140.

Lewis, J.F. \& Jimenez, G.J.G, 1991, Duarte Complex in the La Vega-Jarabacoa-Janico area, central Hispaniola; Geologic and geochemical features of the sea floor during the early stages of arc evolution, Geological society of America, Special paper 262, 1991.

Mann, P., Draper, G., and Lewis, J.F., 1991, An overview of the geologic and tectonic development of Hispaniola, Geological Society of America Special paper 262, 1-28.

Mann, P., Burke, K., and Matumoto, T.,1984, Neotectonics of Hispaniola; plate motion, sedimentation and seismicity at restraining bend, Earth \& Planetary Science Letters, $70,311-324$.

Maresch, W.V., 1977, Experimental studies on glaucophane: an analysis of present knowledge, Tectonophysics, 43, 109125 .

Maruyama, S., Cho, M., and Liou, J.G., 1986, Experimental investigations of blueschist-transition equilibria: pressure dependence of $\mathrm{Al}_{2} \mathrm{O}_{3}$ contents in sodic amphiboles-a new geobarometer, Geological society of America Memoir 164, 1-16. 
Mattson, P.H., 1979, Subduction, buoyant, braking, flipping, and strike-slip faulting in the northern Caribbean, Journal of Geology, 87, 293-304.

Miyashiro, A., 1974, Volcanic rock series in island arc and active continental margins, American Journal of Science, $274,321-355$.

Moore, D.E.,1986, Petrology and tectonic implications of the blueschists bearing Puerto Nuevo melange complex, Vezcairo peninsula, Baja California Sur, Mexico, Geological Society of America Memoir 164, 43-58.

Mullen, E.D., 1983, $\mathrm{MnO} / \mathrm{TiO}_{2} / \mathrm{P}_{2} \mathrm{O}_{5}$ : a minor trace element descriminant for basaltic rocks of oceanic environments and its implications for petrogenesis, Earth and Planetary Science Letters, 62, 53-62

Nagle, F., 1979, Geology of the Puerto Plata area, Dominican Republic, in Lidz, B., and Nagle, F., eds., Hispaniola tectonic focal point of the northern Caribbean; Three studies in the Dominican Republic; Miami Geological Society, p. 1-28.

Nagle, F., 1974, Blueschist, eclogite, paired metamorphic belts, and the early tectonic history of Hispaniola Geological Society of America Bulletin, 85, 1461-1466. 
Nakajima, T., Banno, S., and Suzuki, T., 1977, Reactions leading to the disappearance of pumpellyite in low-grade metamorphic rocks of the Sanbagawa metamorphic belt in central Shikoku, Japan, Journal of Petrology, 18, 263284 .

Newton, R.C., 1986, Metamorphic temperatures and pressures of Group B and C eclogites, Geological Society special paper, 164, 17-30.

Newton, R.C., and Smith, J.V.,1967, Investigations concerning the breakdown of albite at depth in the earth, Journal of Geology, 75, 268-286.

Nitsch, K., 1971, Stabiltatsbeziehungen von prehnitund pumpellyithaltigen paragensen, Contributions to Mineralogy and Petrology, 30, 240-260.

Owen, C., 1989, Magmatic differentiation and alteration in isofacial greenschists and blueschists, Shuksan suite, Washington: statistical analysis of major-element variation, Journal of Petrology, 30, 739-761.

Pardo, G., 1975, Geology of Cuba, in Nairn, A.E.M., and Stehli, F.G., eds., The ocean basins and margins; v.3, The Gulf of Mexico and the Caribbean: New York, Plenum, P. 553-615. 
Pearce, J.A., \& Norry, M.J., 1979, Petrogenic Implications of $\mathrm{Ti}, \mathrm{Zr}, \mathrm{Y} \& \mathrm{Nb}$ variations in Volcanic rocks, Contributions to Mineralogy and Petrology, 69, 33-47.

Pearce, J.A., 1975, Basalt geochemistry used to investigate past tectonic enveronments on Cyprus, Tectnophysics, 25, $41-67$.

Pearce, J.A., \& Cann, J.R., 1973, Tectonic setting of basic volcanic rocks determined using trace element analysis, Earth and Planetary Science Letters, 19, 290-300.

Pindell, J.L., and Draper, G., 1991, Stratigraphy and geological history of the Puerto Plata area, northern Dominican Republic, Geological Society of America Special Paper, 262, 99-114.

Platt, J.P., 1975, Metamorphic and deformational processes in Franciscan Complex, California: Some insights from the Catalina Schist terrane, Geological Society of America Bulletin, 86, 1337-1347.

Raleigh, C.B., Paterson, M.S., 1965, Experimental deformation of serpentinite and its tectonic implications, Journal of Geophysical Research, 70, 3965-3985.

Rankama, K., and Sahama, T.G., 1968, Geochemistry, The University of Chicago press, Chicago and London, pp.912. 
Raymond, A., 1984, Classification of melanges, Geological. Society Special Paper 198, 7-20.

Schiffman, P., and Liou, J.G., 1983, Synthesis of Fepumpellyite and its stability relations with epidote, Journal of Metamorphic Geology, 1, 91-102.

Schiffman, P., and Liou, J.G., 1980, Synthesis and stability of Mg-Al pumpellyite, Journal of Petrology, 21, 441-474.

Sen, G., Hickey-Vargas, R., Waggoner, D.G., Maurrasse, F., 1988, Geochemistry of basalts from the Dumisseau formation southern Haiti: implications for the origin of the Caribbean sea crust, Earth and Planetary Science Letters, 87, 423-437.

Sorenson, S.S., 1990, Geochemical evolution fo high-T hydrothermal fluids in a Plaeo-subduction zone, V.M. Goldschimidt conference, Program and Abstracts, p82.

Sorenson, S.S., 1986, Petrologic and geochemical comparison of the blueschist and greenschist units of Catalina Schist terrane, Southern California; Geological Society of America Memoir 164, 59-75.

Taylor, H.P., and Coleman, R.G., 1968, $0^{18 / 0^{16}}$ ratios of coexisting minerals in glaucophane-bearing metamorphic rocks, Geological Society of America Bulletin, 79, 17271756 . 
Thompson, R.N., Morrison, M.A., Hendry, G.L., and Parry, S.J., 1984, An assessment of the relative roles of crust and mantle in magma genesis: an elemental approach, Philosophical Transactions of Royal Society of London, A310, 549-590.

Troger, W.E., (english edition of fourth German edition by Bambauer, H.U., Taborszky, F., and Trochim, H.D.), 1979, optical determination of rock-forming minerals, E. Schweizerbart'sche Verlagsbuchhardlung, Stuttgart, pp. 189.

Vila, J.M., Boissen, D., Butterlin, J., Feinburg, H., and Pubellier, M., 1987, Le complexe chaotique fini-eocent de Chouchou (Massif du Nork d'Haiti; Un enregistrement du debut des decrochements senestres nord-caraibes; Paris, France, Comptes Rendus de lsa Academie des Sciences, v.304, p.39-42.

Winkler, H.G.F.,1979, Petrogenesis of Metamorphic Rocks 5th edition Springer, Berlin, p. 348.

Yardley, B.W.D., 1989, An Introduction to Metamorphic Petrology, Longman Earth Science Series, U.K., pp.248. 
APPENDIX I

GEOCHEMICAL SPECIMEN PREPARATION 


\section{POWDERING}

1. Cut samples into slices (water lubricated saw was used) of about 0.25 inch thick.

2. Clean all the visible saw marks using sand paper.

3. Clean the slabs ultrasonically in deionized water (in beakers) for about 10 minutes to remove loose powder.

4. Dry samples.

5. Wrap each slab in plastic bags (to avoid metal contamination from hammer) and break dry samples into pieces of approximately $1 / 4$ inch.

6. Precontaminate the shatter box with the sample.

7. Thirty to thirty five cubic centimeters of rock chips put into alumina shatter box and crushed for 1 to 2 minutes.

\section{IGNITION}

1. Rinse quartz crucibles with deionized distilled water and dry in oven for an hour.

2. Rinse bottles and dry.

3. Weigh quartz crucibles.

4. Weigh $0.6 \mathrm{gm}$ sample on paper, then transfer to the crucible.

5. Clean rim.

6. Weigh crucible + sample.

7. Put into furnace tray ( 6 at a time). 
8. Ignite 30 minutes at $950^{\circ} \mathrm{C}$.

9. Cool 5 minutes in air.

10. Transfer to desiccator cabinet for 30 minutes.

11. Weigh

12. Crunch and transfer to bottles.

13. Calculate loss on ignition

LOI $=$ (Weight loss/weight of sample) $\times 100$

\section{CONDITIONING OF GRAPHITE CRUCIBLES}

1. Scrape new crucibles vigorously to remove concentric grooves.

2. Scrape used crucibles lightly to remove clinging glass and loose graphite.

3. Rinse with deionized water.

4. Dry at $110^{\circ} \mathrm{C}$ for 30 mins. in desiccator.

5. Heat at $800^{\circ} \mathrm{C}$ for 5 mins. (4-5 at a time).

6. Cool on bricks for 10-15 mins.

7. Return to aluminium pans and store in desiccator.

\section{FUSION}

1. Weigh dry bottles.

2. Add 50ml Pd-spiked $\mathrm{HNO}_{3}$ with automatic pipette.

3. Reweigh bottle plus solution. 
4. Take crucible, record the crucible number and sample number.

5. Weigh on paper and transfer to crucible $0.8000 \pm 0.0008 \mathrm{gm}$ $\mathrm{LiBO}_{2}$.

6. Make a depression with a mixer in center of $\mathrm{LiBO}_{2}$.

7. Weigh on paper and transfer $0.2000 \pm 0.0002 \mathrm{gm}$ samples.

8. Mix with clip avoiding scraping sides.

9. Fuse 7 mins at $1060^{\circ} \mathrm{C}$.

10. Swirl.

11. Fuse 7 mins at $1060^{\circ} \mathrm{C}$.

12. Dump into numbered bottle.

13. Cap and shake for 60 mins.

14. Let crucible cool, replace in numbered aluminium pan and later check for adhering glass - present add to bottle and shake 60 mins more.

15. Filter through dry funnel using \#40 filter paper into labelled bottle. 
APPENDIX II

124 


\section{TABLE: II-1. MAJOR ELEMENT DATA FROM RIO SAN JUAN COMPLEX}

\begin{tabular}{|c|c|c|c|c|c|c|c|c|c|c|c|c|c|c|}
\hline UNITS & SAMPLE & $\mathrm{SiO} 2$ & $\mathrm{TiO} 2$ & $\mathrm{Al} 2 \mathrm{O} 3$ & $\mathrm{Fe} 2 \mathrm{O} 3$ & $\mathrm{MnO}$ & $\mathrm{MgO}$ & $\mathrm{CaO}$ & $\mathrm{Na} 2 \mathrm{O}$ & $\mathrm{K} 2 \mathrm{O}$ & $\mathrm{P} 2 \mathrm{O} 5$ & LOI $T$ & Total & $\mathrm{FeO}$ \\
\hline HICOTEA & 38 & 58.18 & 0.61 & 15.46 & 6.92 & 0.11 & 6.13 & 7.65 & 2.25 & 2.13 & 0.19 & 2.81 & 99.64 & 6.23 \\
\hline HICOTEA & $84-20$ & 51.23 & 0.71 & 18.56 & 7.9 & 0.13 & 4.07 & 12.2 & 3.53 & 1.25 & 0.2 & 3.87 & 99.8 & 7.11 \\
\hline PUERCA & $83-198$ & 52.11 & 0.54 & 18.53 & 9.48 & 0.32 & 6.25 & 10.6 & 1.72 & 0.1 & 0.09 & 3.31 & 99.78 & 8.53 \\
\hline PUERCA & $84-13$ & 54.35 & 0.79 & 17.99 & 8.82 & 0.12 & 4.32 & 9.16 & 3.16 & 1.04 & 0.19 & 2.7 & 99.94 & 7.93 \\
\hline PUERCA & $84-77$ & 55.79 & 0.73 & 16.02 & 8.28 & 0.08 & 6.68 & 7.45 & 3.86 & 0.81 & 0.19 & 3.31 & 99.88 & 7.45 \\
\hline PUERCA & $83-142 b$ & 48.04 & 0.56 & 14.01 & 7.82 & 0.18 & 5.3 & 19.3 & 2.97 & 0.47 & 0.23 & 9.23 & 99.85 & 7.04 \\
\hline JAGUA & $83-142 d$ & 46.87 & 3.23 & 14.23 & 17.4 & 0.26 & 4.96 & 8.72 & 3.13 & 0.45 & 0.53 & 1.2 & 99.73 & 15.6 \\
\hline JAGUA & $84-16$ & 49.18 & 1.99 & 13.91 & 13.6 & 0.18 & 6.1 & 11.6 & 2.92 & 0.54 & 0.18 & 0.6 & 100.3 & 12.3 \\
\hline JAGUA & $84-100$ & 55.77 & 0.59 & 13.56 & 8.83 & 0.17 & 9.03 & 5.92 & 4.92 & 0.61 & 0.11 & 1.7 & 99.52 & 7.95 \\
\hline ARROYA & $84-12$ & 53.32 & 1.57 & 14.8 & 11.1 & 0.18 & 9.49 & 2 & 4.79 & 2.19 & .16 & .11 & 99.56 & 9.95 \\
\hline ARROYA & $83-144$ & 54.53 & 0.04 & 3.4 & 6.32 & 0.11 & 20.3 & 12.5 & 1.53 & 0.17 & 0.01 & 2.55 & 99.59 & 5.68 \\
\hline ARROYA & $84-78 b$ & 50.95 & 1.95 & 12.96 & 13.9 & 0.2 & 6.7 & 7.98 & 4.89 & 0.62 & .11 & 2.67 & 100.2 & 12.5 \\
\hline ARROYA & $84-82$ & 54 & 0.8 & 18.16 & 8.64 & 0.12 & 4.18 & 9.12 & 3.2 & 1.03 & 0.18 & 2.68 & 99.42 & 7.78 \\
\hline${ }^{*}$ Tholeiiti & $c$ basalt & 53.8 & 2 & 13.9 & 10.3 & 0.2 & 4.1 & 7.9 & 3 & 1.5 & 0.4 & & & 9.3 \\
\hline
\end{tabular}




\section{TABLE: II-2. TRACE ELEMENT DATA FROM RIO SAN JUAN COMPLEX}

\begin{tabular}{llrrrrrrrrrrrrrrr} 
UNITS & SAMPLE & \multicolumn{1}{c}{$\mathrm{Ni}$} & $\mathrm{Ba}$ & $\mathrm{Cr}$ & $\mathrm{Sc}$ & $\mathrm{Sr}$ & $\mathrm{Zn}$ & $\mathrm{Co}$ & $\mathrm{V}$ & $\mathrm{Nb}$ & $\mathrm{Cu}$ & $\mathrm{Ti}$ & $\mathrm{Zr}$ & $\mathrm{Y}$ & $\mathrm{La}$ & $\mathrm{P}$ \\
\hline Hicotea & $83-138$ & 109 & 991 & 287 & 27 & 434 & 83 & 24 & 154 & 10 & 27 & 3677 & 223 & 29 & 39 & 897 \\
Hicotea & $84-20$ & 74 & 558 & 113 & 30 & 585 & 73 & 22 & 239 & 4 & 40 & 4252 & 117 & 21 & 24 & 939 \\
Puerca & $83-198$ & 43 & 83 & 24 & 44 & 433 & 159 & 30 & 258 & n.d. & 132 & 3192 & 37 & 15 & 2 & 433 \\
Puerca & $84-13$ & 36 & 622 & 79 & 35 & 557 & 94 & 23 & 277 & 1 & 68 & 4802 & 100 & 24 & 15 & 864 \\
Puerca & $84-77$ & 55 & 216 & 79 & 32 & 242 & 69 & 24 & 224 & 1 & 63 & 4422 & 75 & 24 & 10 & 863 \\
Puerca & $83-142 \mathrm{~b}$ & 66 & 249 & 187 & 33 & 428 & 78 & 23 & 182 & 2 & 281 & 3289 & 70 & 35 & 14 & 1085 \\
Jagua & $83-142 \mathrm{~d}$ & 94 & 148 & 136 & 48 & 137 & 179 & 55 & 433 & 4 & 47 & 19380 & 233 & 85 & 7 & 2248 \\
Jagua & $84-16$ & 61 & 67 & 173 & 47 & 139 & 120 & 40 & 354 & 2 & 20 & 12003 & 125 & 50 & 6 & 809 \\
Jagua & $84-100$ & 350 & 245 & 824 & 24 & 72 & 83 & 28 & 179 & 2 & 34 & 3563 & 91 & 14 & 5 & 496 \\
Arroya & $84-12$ & 107 & 1607 & 292 & 48 & 73 & 171 & 39 & 338 & 3 & 68 & 9547 & 101 & 47 & 4 & 723 \\
Arroya & $83-144$ & 1968 & 11 & 2952 & 4 & 27 & 68 & 58 & 30 & n.d. & 3 & 105 & 2 & 2 & $n . d$. & 48 \\
Arroya & $84-78 \mathrm{~b}$ & 139 & 226 & 114 & 46 & 36 & 115 & 44 & 389 & 1 & 16 & 11837 & 131 & 55 & 6 & 477 \\
Arroya & $84-82$ & 32 & 627 & 82 & 34 & 564 & 88 & 22 & 290 & 2 & 70 & 4826 & 106 & 24 & 15 & 833 \\
\hline
\end{tabular}

